\title{
Archeological Testing of 41KM3 The Red Creek Site A Burned- Rock Midden Site Kimble County, Texas
}

Jerry Henderson

Follow this and additional works at: https://scholarworks.sfasu.edu/ita

Part of the American Material Culture Commons, Archaeological Anthropology Commons, Environmental Studies Commons, Other American Studies Commons, Other Arts and Humanities Commons, Other History of Art, Architecture, and Archaeology Commons, and the United States History Commons

Tell us how this article helped you.

This Article is brought to you for free and open access by the Center for Regional Heritage Research at SFA ScholarWorks. It has been accepted for inclusion in Index of Texas Archaeology: Open Access Gray Literature from the Lone Star State by an authorized editor of SFA ScholarWorks. For more information, please contact cdsscholarworks@sfasu.edu. 


\section{Archeological Testing of 41KM3 The Red Creek Site A Burned-Rock Midden Site Kimble County, Texas}

\section{Licensing Statement}

This is a work produced for the Texas Department of Transportation (TxDOT) by the report producer. TxDOT and the report producer jointly own all rights, title, and interest in and to all intellectual property developed under TXDOT's contract with the report producer. The report may be cited and brief passages from this publication may be reproduced without permission provided that credit is given to both TXDOT and the report producer. Permission to reprint an entire chapter, section, figures or tables must be obtained in advance from either the Supervisor of the Archeological Studies Branch, Environmental Affairs Division, Texas Department of Transportation, 125 East 11th Street, Austin, Texas, 78701 or from the report producer. 


\title{
Archeological Testing of 41KM3 The Red Creek Site A Burned-Rock Midden Site Kimble County, Texas
}

\author{
B y \\ Jerry Henderson
}

April 1997

\section{Environmental Affairs Division Texas Department of Transportation}




\begin{abstract}
In May and June of 1988, archaeological testing of Site 41KM3, the Red Creek Site, was conducted by the Texas Department of Transportation, at that time the State Department of Highways and Public Transportation (SDHPT), in preparation for the construction of FM 3480 in Kimble County. The Red Creek Site is a large, multiple midden site along the northern terrace of the Llano River near its confluence with Red Creek. Most of the site lay outside the right-of-way and testing was confined to the southern periphery of the site, along the terrace slope. Most of the materials recovered from this area seemed to be the result of secondary deposition. Artifacts representing Late Paleoindian through Late Prehistoric cultural periods were recovered, with a preponderance of the material representing the Middle Archaic. Testing resulted in the designation of Site $41 \mathrm{KM} 3$ as a State ArcheologicalLandmark. The intact portions of the site remaining within the right-of-way have been buried under several layers of sterile soil to protect the site from future impact.
\end{abstract}




\section{ACKNOWLEDGMENTS}

The accomplishment of this work was due to the efforts of a good many people from a variety of resources. Within the State Department of Highways and Public Transportation (SDHPT), Kenneth C. Bohuslav coordinated the project as Director of Environmental Studies. Frank A. Weir supervised the fieldwork as Director of the Environmental Studies Archaeology Section. John W. Mills, District Design Engineer for the SDHPT San Angelo District, coordinated the efforts through his district office; and Evers Schmidt, Resident Engineer of the Junction SDHPT Residency, acted as liaison between the district office and the archaeologists. The field crew consisted of Bobby Chenault, Eddie Heath, Bob Hepbum, Charlie Meador, David Murr, Ray Murr, and Monte Walker, of the Junction Residency Office; all performed their work in an exemplary manner. In addition, Chad Bird, a temporary employee of the archaeology staff in Austin, assisted for part of the project. Glenn T. Goode, Milton Bell, and Frank Weir, members of the archaeology staff in Austin, aided in excavating and mapping the site. Mark Denton of the Texas Antiquities Committee was very helpful in arriving at a plan to conserve uninvestigated portions of the site within the right-of-way. A heartfelt "thank you" to one and all. 


\section{Contents}

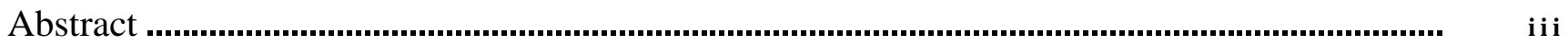

Acknowledgments ..................................................................................................................................... V

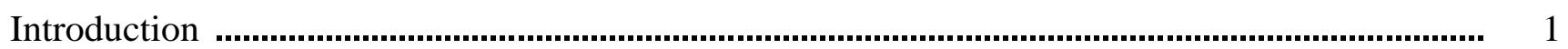

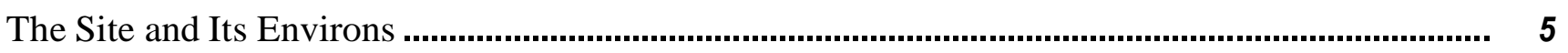

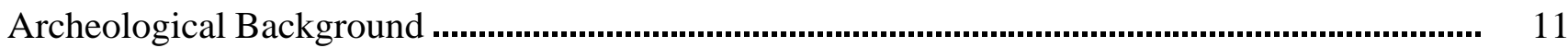

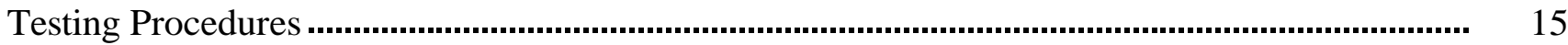

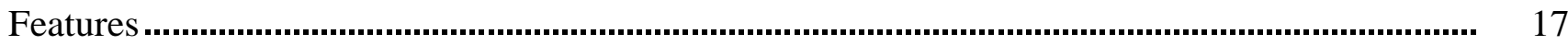

Burned-Rock Middens ........................................................................................................... 17

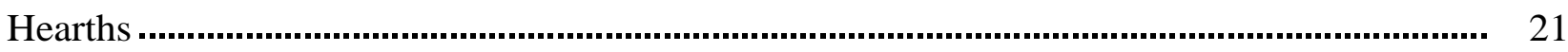

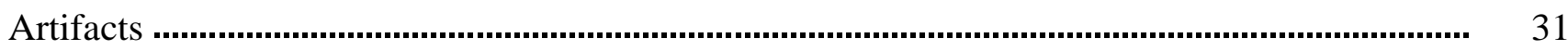

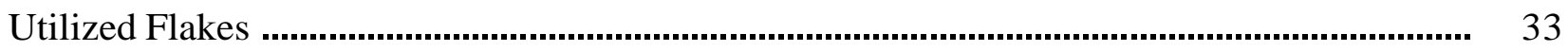

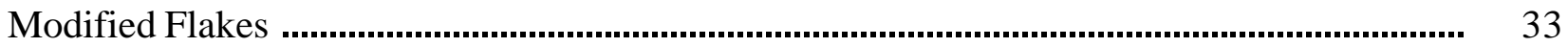

Nondiagnostic Bifaces n.............................................................................................................

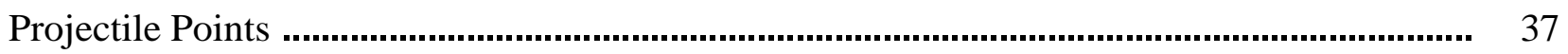

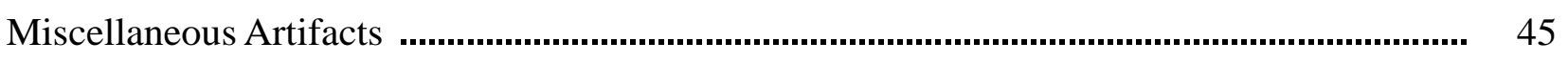

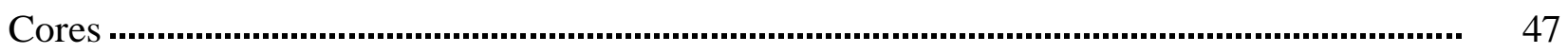

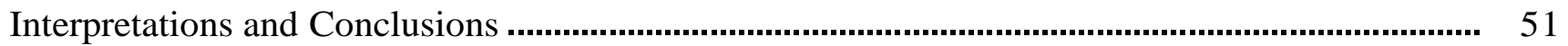

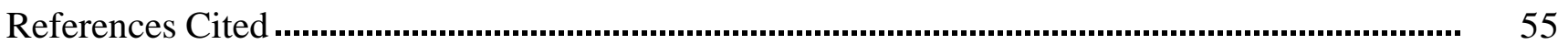




\section{List OF Figures}

Figure 1. Location of FM 3480 project and Site 41KM3 in Kimble County.................................. 2

Figure 2. East end of project showing rights-of-way, backhoe trenches, and test units...................... 3

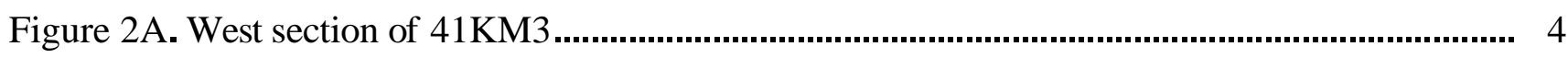

Figure 2B . East section of 41 KM3 ..........................................................................................

Figure 3. Site environs. A, Red Creek, looking upstream; B, waterfall south of Site 41KM3 ........... 7

Figure 4. Testing near terrace edge. A, east excavation area, looking south ; $\mathrm{B}$, looking west ............ 8

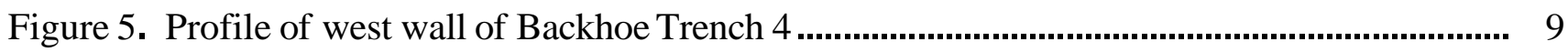

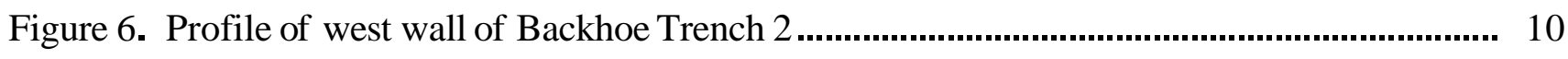

Figure 7. Feature 3. A, surface plotting of Feature 3 before testing; B, crew exposing Feature $3 \ldots . . .18$

Figure 8. Feature 3 as exposed in test unit. A, photograph of top of feature; B, plan view.............. 19

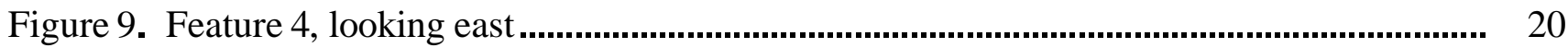

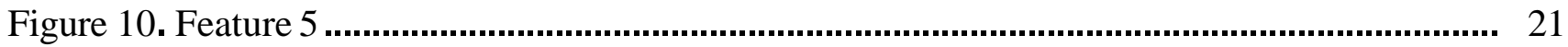

Figure 11. Feature 6. A, photo of exposed feature, looking north; B. plan drawing ..........................23

Figure 12. Feature 7. A, Photo of exposed feature; B. plan drawing .............................................. 25

Figure 13. Feature 7. A, photo of west half of Feature 7 at Level 1; B. drawing in cross section...... 26

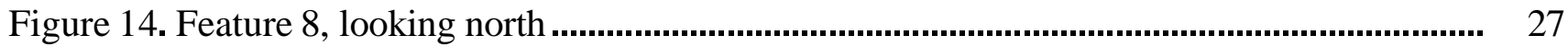

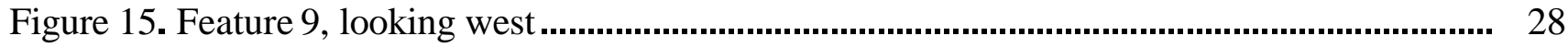

Figure 16. Feature 10. A, photo of exposed southern portion ;B, plan drawing of exposed portion. 30

Figure 17. Small, thin utilized flakes ...........................................................................................

Figure 18. Large, chunky utilized flakes ...................................................................................... 34

Figure 19. Modified flakes .......................................................................................................... 36

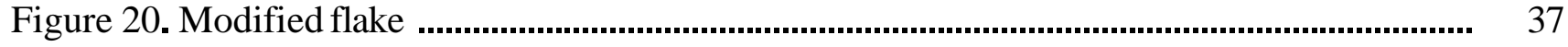

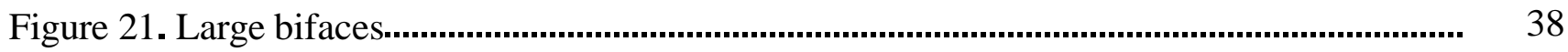

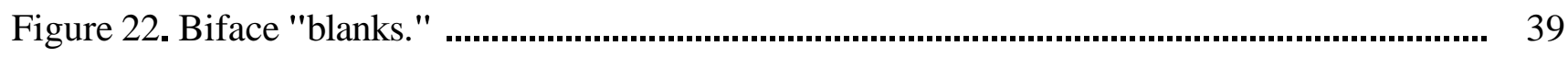

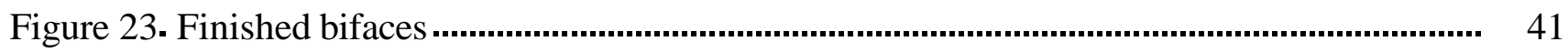

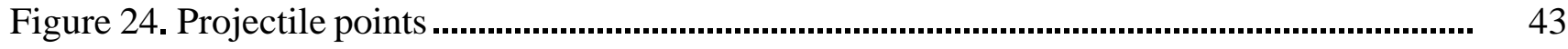

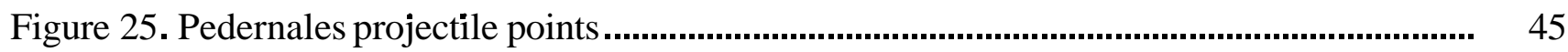

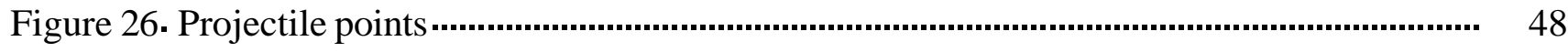

Figure 27. Miscellaneous artifacts ....................................................................................... 50

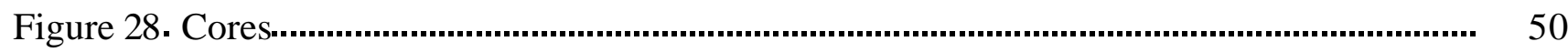




\section{LIST OF TABLES}

Table 1. Provenience of lithic debitage............................................................................. 32

Table 2. Provenience of utilized flakes ................................................................................... 35

Table 3. Provenience of modified flakes ................................................................................. 35

Table 4. Provenience of bifaces....................................................................................... 40

Table 5. Pedernales projectile points.......................................................................................... 46

Table 6. Contracting-Stemmed projectile points........................................................................ 46

Table 7. Provenience of miscellaneous dart-point fragments........................................................ 49

Table 8. Provenience of cores ............................................................................................ 49

Table 9. Synopsis of diagnostic artifacts.......................................................................... $\quad 53$ 


\section{INTRODUCTION}

In the fall of $\mathbf{1 9 8 7}$ a proposal was initiated by the then State Department of Highways and Public Transportation (SDHPT) to upgrade a gravel-surfaced county road in Kimble County into a paved state Farm-to-Market road. The road, County Road 1635, which was to become FM 3480, was located about 6.5 miles south of the town of London and extended westward from RM 385 approximately 1.8 miles to US 377 (Fig. 1). About 0.2 mile from the east end of the project the road made a lowwater crossing at Red Creek (Fig. 2); this crossing was located approximately 0.25 mile above the creek's confluence with the Llano River.

Initial plans called for the developed roadway to be contained within the existing county right-of-way except at the east end of the project, where an alignment correction would have required approximately $\mathbf{4}$ acres of new right-of-way. This new right-of-way would have extended eastward to RM 385 from the western approach to Red Creek and would have been located north of the existing county road. In this general area-east of the Red Creek crossing but along both sides of the existing county road - archeological site 41K M 3, the Red Creek Site, was present. The main body of the site was located on the north side of the county road.

Reconnaissanceand consultation between archeologists and engineers from the SDHPT and representatives from the Texas Antiquities Committee (TAC) proved beneficial in that it was possible to redesign the planned roadway to bypass the most significant portions of the site. A revised alignment was drawn up in which the new roadway in the vicinity of the Red Creek Site was moved as far south as possible to avoid major impact to archeologicaldeposits on the north side of the county road.

The revised plans called for containing the developed highway as much as possible within the existing right-ofway and, where necessary, acquiring most of the additional right-of-way from south of the county road-an area where archeological deposits were peripheral to the main body of the site. In this way, a narrow strip of new right-of-way averaging only $10 \mathrm{ft}$. wide was required along the north side of the road where denser portions of the site were located. Within this strip, site deposits were to be covered with a layer of introduced soil in order to protect the site from further impact.

A result of these avoidance/protection measures was that test excavations were conducted only on the south side of the county road, except for one test unit into a burned-rockfeature on the north side of the road that was already under impact from existing conditions of erosion and road-grading activities.

Archeological testing was initiated on May 16, 1988, and terminated June 24, 1988. Fieldwork was accomplished by a crew of SDHPT employees from the Junction Residency Office under the direction of Jerry Henderson, a member of the SDHPT professional cultural resources staff, and was performed under the Memorandum of Agreement between the SDHPT and the TAC. Total time spent in the field was approximately 1014 person-hours.

As a result of this project the publicly owned portions of the Red Creek Site have been designated by the TAC as a State Archeological Landmark.

After testing was completed, the SDHPT honored its commitment to protect the site, and covered the remaining portions of the site that lay within the right-of-way on the north side of the road with several layers of introduced soil. This soil was leveled to prevent future erosion problems and to avoid further impact to the site. The procedure was conducted on August 3, 1989, and was monitored by Frank A. Weir, Director of Archaeological Studies at the SDHPT. As a result of this process, all evidence of the publicly owned portions of the site has been concealed and whatever remains of the site within the FM 3480 right-of-way has been effectively preserved and protected in perpetuity. 
This Page Redacted Per THC Policy 


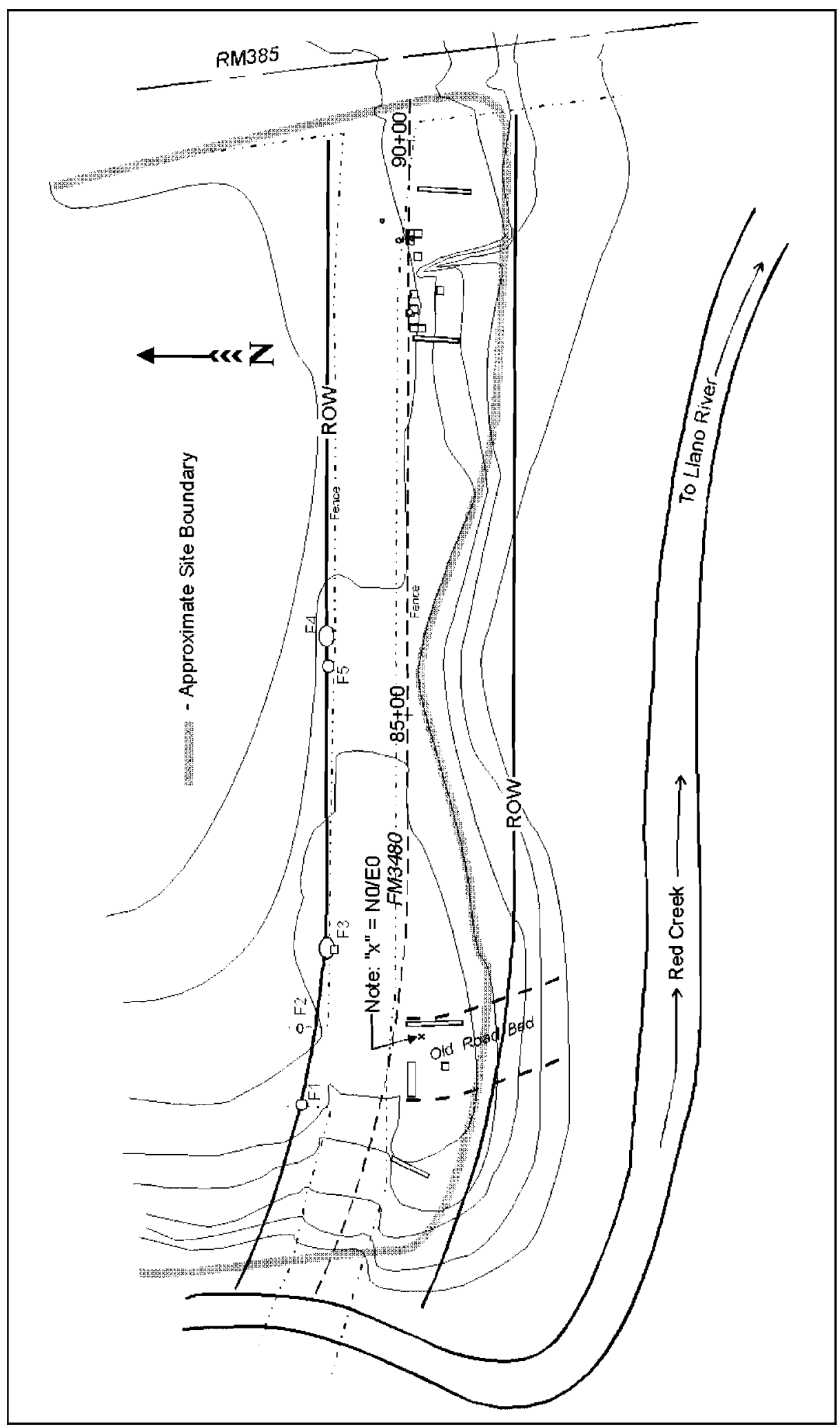

FIGURE 2. East end of project showing rights-of-way, Site 41KM3, backhoe trenches, and test units. 


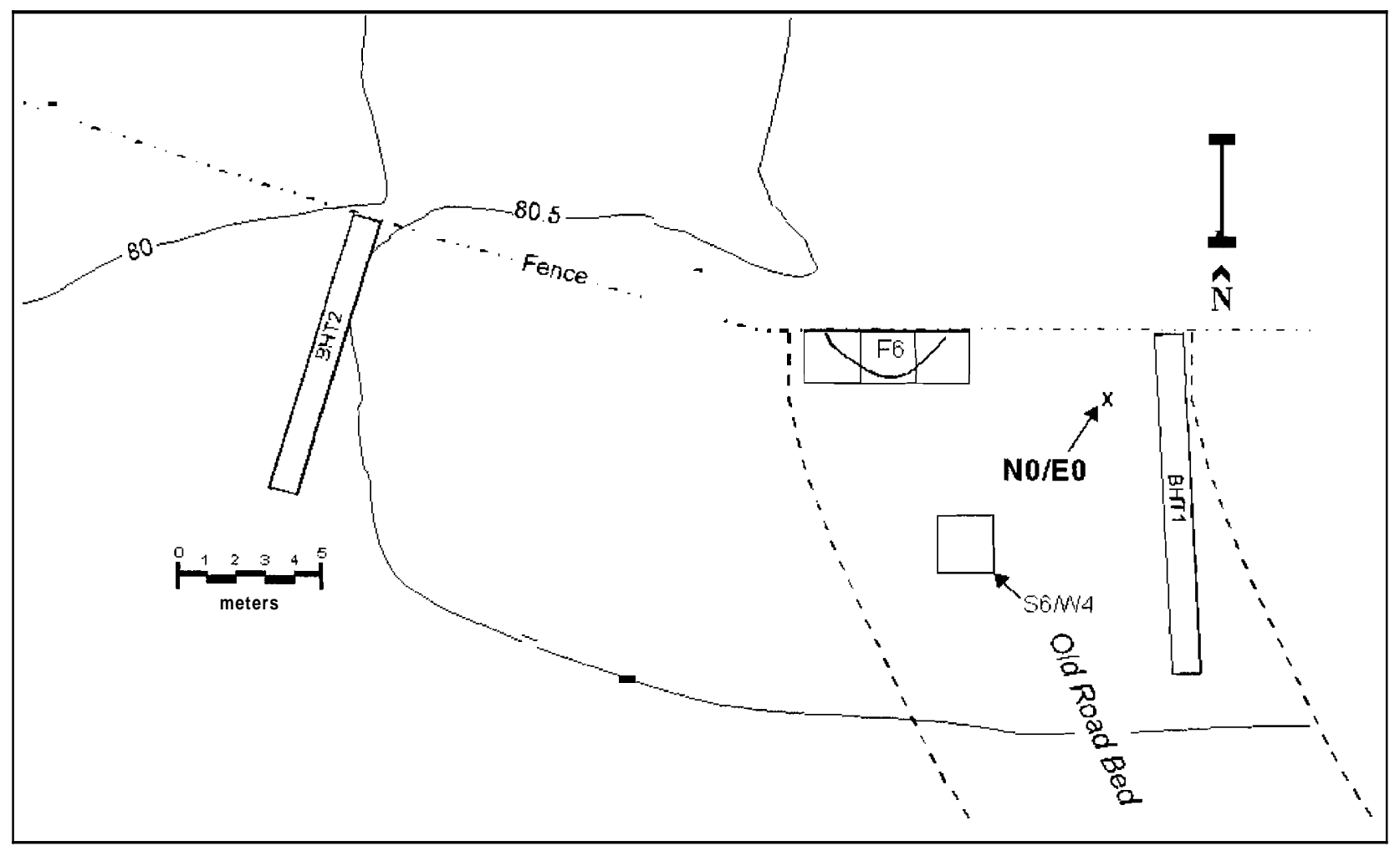

Figure 2A. West section of 41KM3.

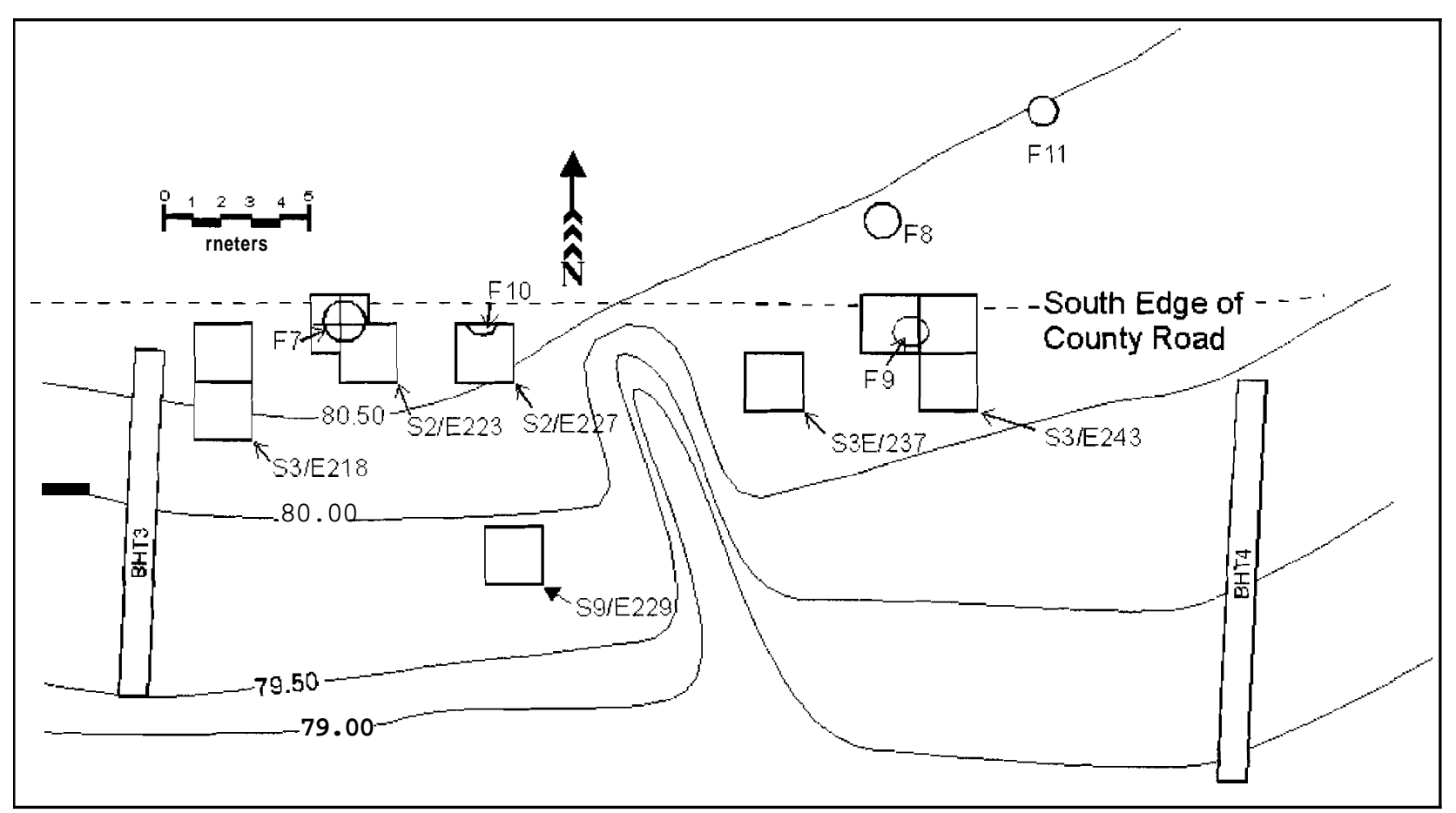

Figure 2B. East section of 41KM3. 


\section{The Site ANd Its Environs}

Kimble County lies along the southern margin of Fenneman's (1938) Great Plains physiographic province, where it merges with the Edwards Plateau. Thus it exhibits characteristics of both the Great Plains and the Texas Hill Country, taking on a flavor of grassland savannahs and upland prairies to the northwest, and rugged dissected hills and spring-fed streams to the southeast.

The Balcones Escarpment, which bounds the Edwards Plateau on the south, marks a single, definitive fault line that extends eastward from the Rio Grande near the city of Del Rio, runs just south of Bandera County, and then curves northeastward to intersect the Colorado River just north of the city of Austin. This line is characterized by a series of southward- and eastward-facing,eroded limestone hills, and is usually thought of as the boundary between upland and lowland Texas.

With its geographic parameters thus defined, the flora and fauna of Kimble County can be viewed as a mixture of forms found on both the Edwards Plateau and the Great Plains, and somewhat cut off from the lowland coastal plains. That is, the plant and animal life is an admixture of woodlands, grasslands, plains, and desert species. This particular biota is what Blair calls the Balconian Province (Blair 1950). Throughout the region live oak (Quercus virginiana), shin oak (Q.annulata), mesquite (Prosopis juliflora var. glandulosa), and Mexican cedar (Juniperus mexicana) are the dominant woody vegetation (Gould 1969). Prickly pear (Opuntia sp.) and other cacti are present in the uplands (Gould 1969). Many species of grasses are present, including hairy triodia (Triodia pilosa), little bluestem (Andropogon scoparius), side-oats grama (Bouteloua curtipendula), hairy grama (B. hirsuta), Indian grass (Sorghastrum nutans), common curly mesquite (Hilaria elangeri), buffalo grass (Buchloe dactyloides), fall witch grass (Leptoloma cognatum), tumble love grass (Eragrostis sessilispica), wild ryes (Elymus sp.), and Texas grama (B. rigidisets) (Gould 1969).

Along with the varied plant life, a wide variety of animal life can also be found. Blair (1950) lists 57 species of mammals, 36 species of snakes, 16 lizards, 15 frogs and toads, 7 newts and salamanders, and 1 land turtle.

Important among these, especially in prehistoric times, are bison (Bison), white-tailed deer (Odocoileus virginianus), and antelope (Antelocapra americana).

The geology of the region is sedimentary, with the Llano River cutting through the Segovia Member of the Edwards Limestone of Lower Cretaceous age into the underlying Hensell Sand of the Cretaceous Glen Rose Limestone (Johnson 1994). The region's climate can be described as long hot summers and relatively mild winters (Carr 1967). The average annual temperature is $66.7^{\circ} \mathrm{F}$. (Carr 1967). Carr (1967) records an average annual rainfall of 25 inches, which occurs mostly in two distinct periods, April-May-June and August-September-October.

There are numerous perennial rivers and creeks in the region that have their origins in the study area, their headwaters springing out from the uplands and the interior of the Edwards Plateau, flowing eastward and then southward across the Balcones Escarpment on their way to the Gulf. The Llano River is just such a river. It heads up some $80 \mathrm{~km}$ west of the Red Creek Site, flowing west to east across the middle of Kimble County to join the Colorado River some 120 kilometers east of the site.

The Red Creek Site, 41KM3, is located on the east side of Red Creek, just north of the confluence of Red Creek with the Llano River (Fig. 1). Red Creek flows north to south into the site area, where it makes a sweeping bend to the east and flows west to east along the south side of the site (Figs. 1,2,3A). The creek then turns back to the southeast and enters the Llano River from a northwesterly direction just south of the site. The site, then, is located on a terrace along the east and north sides of Red Creek.

The terrace containing Site 41KM3 rises sometimes gradually, sometimes precipitously, from the creek bed to an elevation some $10 \mathrm{~m}$ above the creek; on the opposite side of the creek, an almost vertical bluff rises some $30 \mathrm{~m}$ from the creek floor (Fig. 3A). The change in elevation from the creek to the Llano River is another abrupt $5 \mathrm{~m}$ or so and is marked by a dramatic waterfall that drops over a small cliff from the higher Red Creek bed into the lower Llano River drainage (Fig. 3B). At the bottom of the waterfall a deep plunge pool has formed that is about a half acre in size and joins the waters of the Llano.

The site, for the most part, sits atop a level stretch of the terrace that parallels the creek for at least $300 \mathrm{~m}$ (Fig. $4 A, B)$. The site extends down the terrace slopes to the west and south in areas where the degree of slope toward the creek is not severe.

Access to the northern reaches of the site was never gained, so its extent in that direction can only be estimated. Looking north from the right-of-way of FM 3480 , one can see surface indications of the site for at least $100 \mathrm{~m}$. The site is not visible to the east of RM 385, nor can it be seen in the road cuts of that highway. It is surmised, then, that the site is contained in that area bounded by RM 385 on the east, Red Creek on the south and west, and an imaginary line at least $100 \mathrm{~m}$ north of FM 3480 on the north (Fig. 2). Thus the site is approximated at 7 to 8 acres in size, or roughly 300 by 
100 m east-west.

The surface of the site is marked by numerous burned-rock features and lithic debris. An intact burnedrock midden (Feature 4 in Fig. 2) is present, partially within the right-of-way on the north side of the road, and a smaller satellite midden or incipient midden (Feature 5 in Fig. 2) is present a few meters west of the larger midden. A buried midden (Feature 3 in Fig. 2) can be seen eroding from the road cut on the north side of the county road, west of Features 4 and 5, and several hearths are visible across the surface of the site (for example, Features 1 and 2 in Fig. 2).

Since access to that portion of the site located north of the right-of-way was not obtained, only those surface features that could be observed from the north right-ofway line, or which could be identified during a hasty pedestrian survey of the area immediately adjacent to the north right-of-way, were recorded.

The site area to the north of the middens has been artificially terraced in the recent past so that human-made ridges of soil, burned rock, and flint have been created across the site in a curvilinear fashion. These terraces no doubt have obscured the integrity of the original patterning of the burned rocks in that area, although definite concentrations are still visible.

Construction of the county road obliterated most of the site that occurred within the county-road right-of-way. Two burned-rock features (probably hearths) were present in the roadbed at the time of investigation(Features 8 and 11 in Fig. 2B), but they appeared to be only the bottommost portions of the original features, the tops having been removed during county-road construction and grading. An abundance of burned rock and flint debris was present along the margins of the roadway, presumably from having been pushed up during blading of the roadbed from original positions somewhere within the existing roadway area.

According to the Soil Survey of Kimble County, Texas (Soil Conservation Service 1982), two different soil types can be found at Site 41KM3: the Shep clay loam on the level terrace tops away from the drainages, and the HextLatom complex on the slopes.

The Shep clay loam is a deep, gently sloping soil typically having a surface layer of brown clay loam about $23 \mathrm{~cm}$ thick, a subsoil of light brown clay loam about $37 \mathrm{~cm}$ thick, and an underlying light brown clay loam with calcium carbonate accumulations to a depth of $2 \mathrm{~m}$ (Soil Conservation Service 1982). The soil is calcareous and moderately alkaline throughout and is found on 1 percent to 5 percent slopes.

The Hext-Latom complex consists of moderately deep to very shallow soils on ridges, knolls, and slopes. The complex is a composite of fine sandy loam, other soils, and rock outcrops overlain with sandstone fragments coated with caliche and fragments of gravel conglomerates (Soil Conservation Service 1982). Slopes range from 3 percent to 12 percent but average 6 percent. Typically, the complex has a surface layer of reddish brown fine sandy loam about $28 \mathrm{~cm}$ thick, a subsoil of reddish brown fine sandy loam about $47 \mathrm{~cm}$ thick, and an underlying reddish yellow fine sandy loam about $60 \mathrm{~cm}$ thick. The underlying layer is about 20 percent calcium carbonate (Soil Conservation Service 1982).

The Hext-Latom soils are ancient soils that formed over rocks of the Cretaceous geological system, a widespread system present throughout most of Kimble County (Soil Conservation Service 1982). The soils formed in loamy, limey sediments; the calcium carbonate accumulated as a result of the region's limited rainfall, which has not been adequate to leach the minerals from the soils (Soil Conservation Service 1982).

The portions of Site 41KM3 that were investigated archeologically appeared to be of the Hext-Latom complex: they were located on or near slopes; had little depth; were composed basically of fine sandy loams mixed with gravels, caliche, and sandstone fragments; and they displayed an abundance of calcium carbonate.

The investigated areas have suffered from extensive denuding, resulting in deflated and degraded surfaces with mixed archeological components-especially along the southern and western slopes of the terrace.

The soil profile as seen in Backhoe Trench 4 (Fig. 5) is typical of those seen in all investigated areas along the south right-of-way, except in the extreme southwestern edge of the site where evidence of recently deposited overbank flooding is present (Fig. 6). The typical profile consists basically of about $10-20 \mathrm{~cm}$ of light tan to gray, dry, silty loam (Zone 1 in Fig. 5) overlying a tan silt mixed with small gravels and cobbles (Zone 2 in Fig. 5). The gravels and cobbles increase with depth and ultimately rest atop bedrock. 

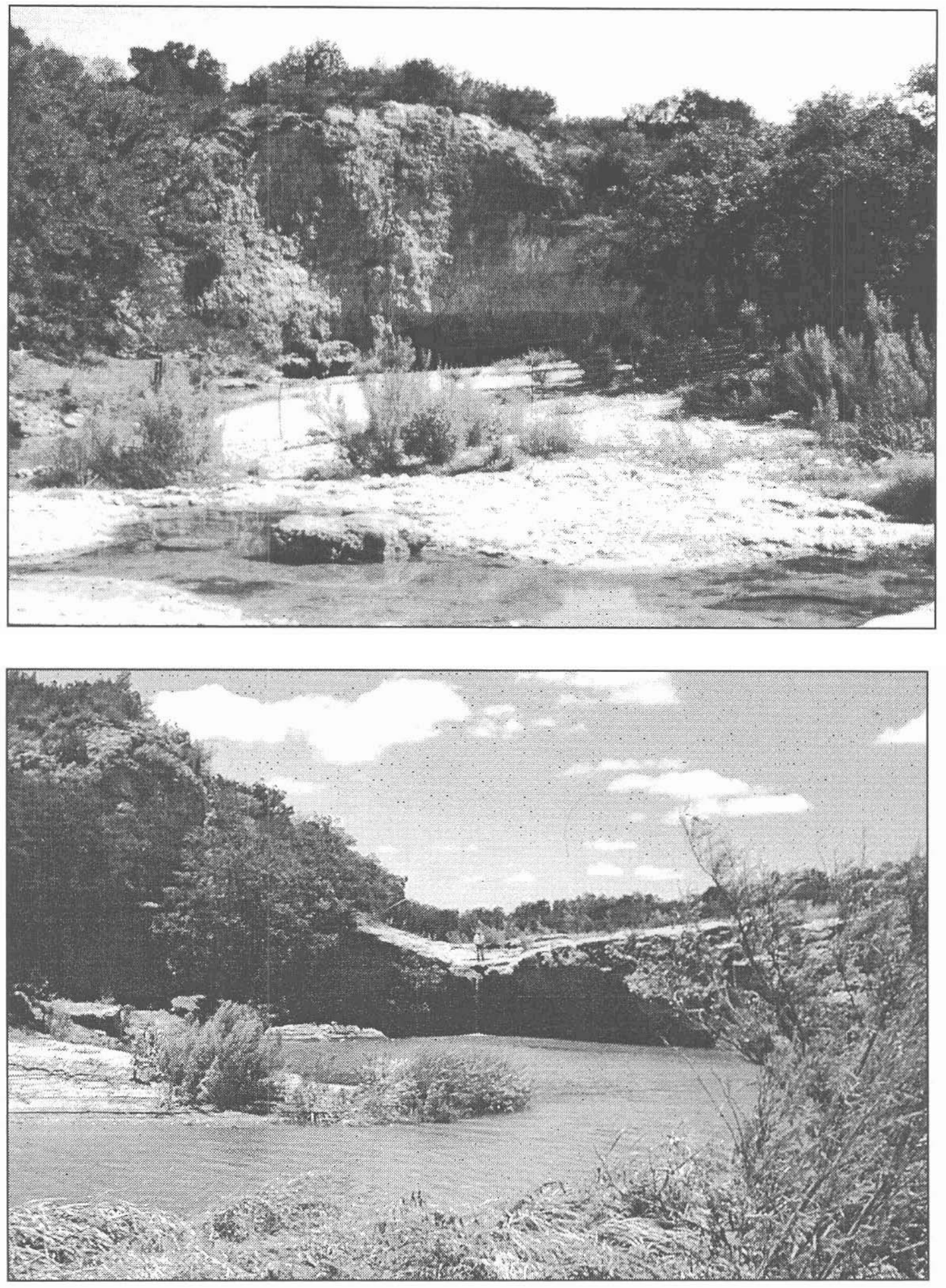

FIGURE 3. Site environs. A (top), Red Creek, looking upstream to the north from a bend in the creek south of the site; B (bottom), waterfall south of Site 41KM3 where Red Creek flows into the Llano River, looking north. 

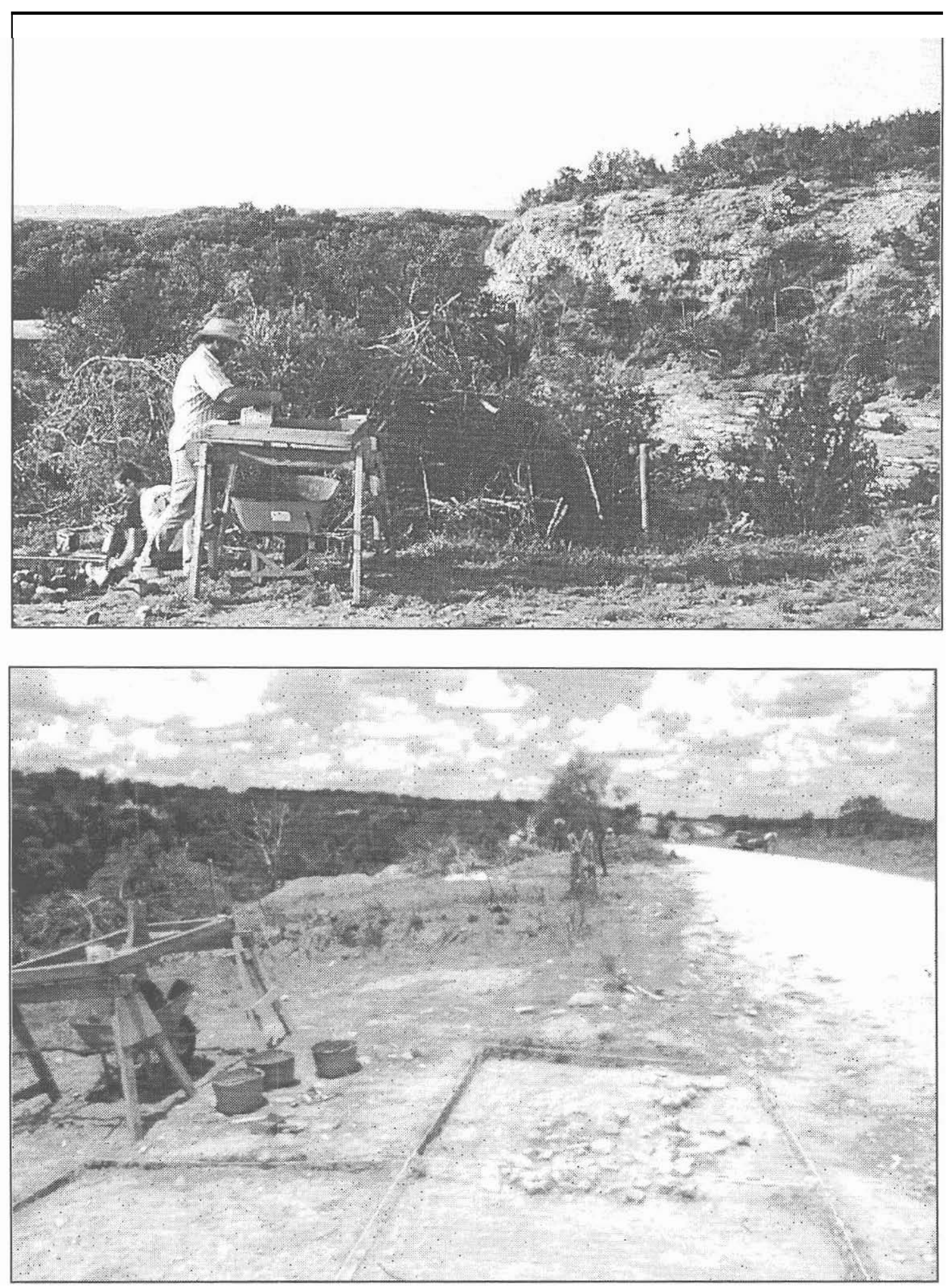

FIGURE 4. Testing near terrace edge. A (top), east excavation area, looking south across Red C reek to bluffs on opposite side of creek; B (bottom), east excavation area, looking west down county road. Red Creek is off terrace edge to the south. Feature 9 is in the foreground. 


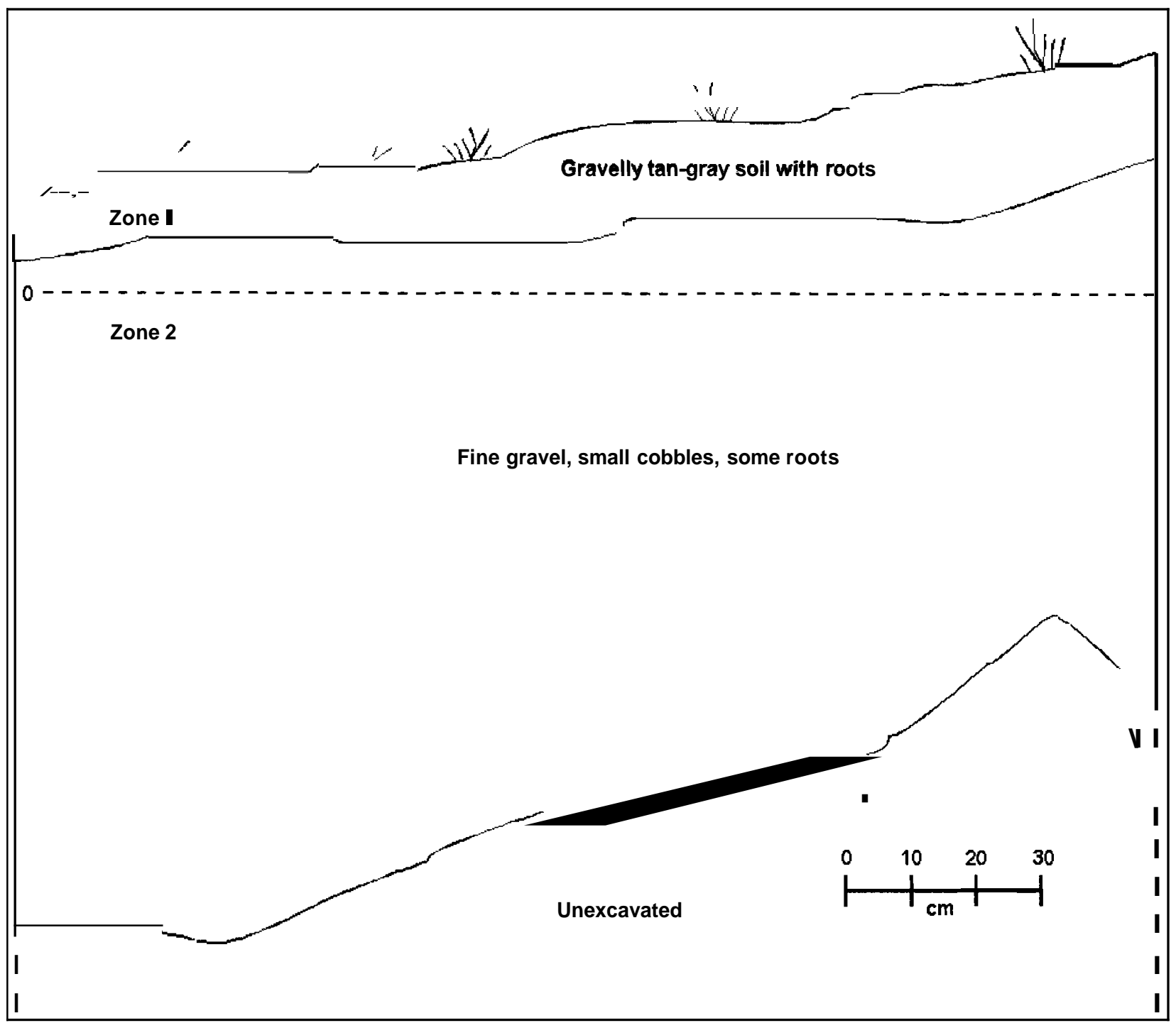

FIGURE 5. Profile of west wall of Backhoe Trench 4. 


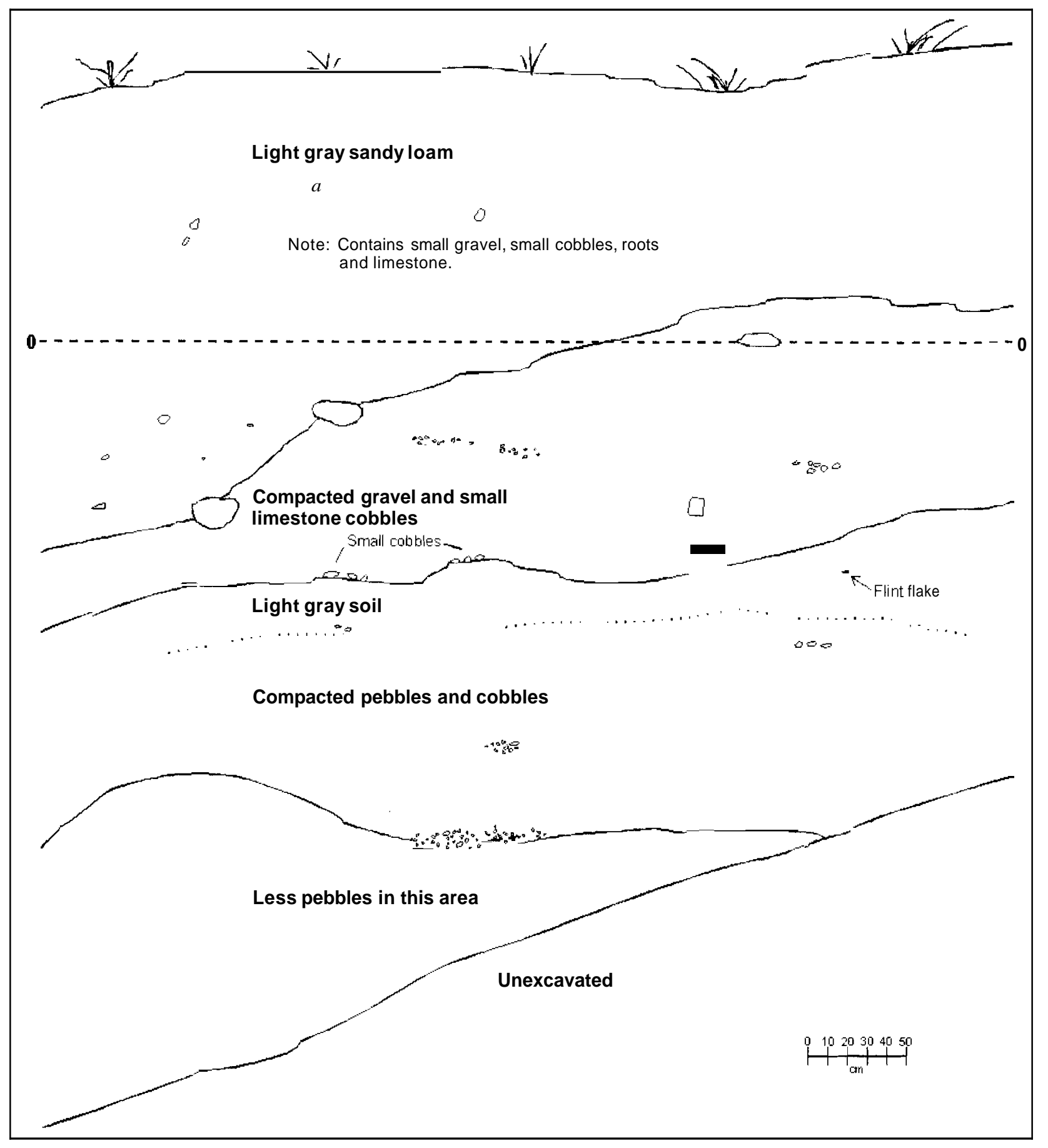

FIGURE 6. Profile of west wall of Backhoe Trench 2. 


\section{Archeological Background}

Kimble County is situated just west of the central portion of what has been defined as the Central Texas Archaeological Region (Weir 1976; Prewitt 1981a; Brown et al. 1982). The four basic culture periods that have been defined for the state and the nation as a whole are included in the Central Texas Archaeological Region as well. These are the Paleoindian Period, the Archaic Period, the Late Prehistoric Period, and the Historic Period.

The earliest cultural period, the Paleoindian, began sometime prior to 10,000 B.C. and represents a period of Late Pleistocene large-game hunting by members of small, highly mobile cultural groups. The Paleoindian Period has been associated with the last glacial period of the Wisconsin Ice Age. The period is recognized archeologically by fluted and lanceolate projectile points, such as Clovis, Folsom, and Plainview, that are sometimes associated with extinct forms of Pleistocene fauna. The period was fairly homogeneous throughout North America, although regional expressions are known.

Several Paleoindian sites have been excavated in the Central Texas Archaeological Region. Some of the more significant ones in the vicinity of Site 41KM3 are the Pavo Real Site in Bexar County (Henderson 1983), the WilsonLeonard Site in Williamson County (Young 1985a), and the Levi Rockshelter Site in Travis County (Alexander 1963).

The Paleoindian Period ended about 6500 B.C. (Weir 1976) upon the extinction of the Late Pleistocene megafauna and the decline of the glaciation. The concomitant need to devise new subsistence strategies in order to deal with the changing environment heralded a new culture period known as the Archaic. The Archaic Period saw a change from the specialized large-game hunters of the Pleistocene to a generalized hunting and gathering pattern with many diverse localized and regional forms. The change was gradual and a transitional Paleoindian/Early Archaic Period is now recognized in some archeologicalcontexts.

An early projectile point type considered to be Late Paleoindian/Early Archaic is the Angostura (Weir 1976). This type has been recovered underlying Early Archaic forms at the Heard Site (Henderson n.d.) and overlying Plainview points at the Wilson-Leonard Site (Young 1985a). At the Wilson-Leonard Site, numerous Angostura points were recovered in association with Gower points, another diagnostic transitional Early Archaic type. Associated with these types and considered typical of the period are large, basinshaped hearths, sometimes $2 \mathrm{~m}$ in diameter and $30 \mathrm{~cm}$ thick (Young 1985a).
Prewitt (1981a) places the Angostura type in the Early Archaic Circleville Phase. He explains that even though the lithic technology is similar to older Paleoindian styles, the subsistence base represented by Angostura points reflects an Archaic hunting and gathering adaptation. Prewitt (1981a) proposes a date of 8500 B.P. to 7000 B.P. for the Circleville Phase.

The Archaic Period itself is widely known throughout Central Texas and makes up the bulk of the archeological record. The period has been divided into five phases by Weir (1976) and eleven phases by Prewitt (1981a), based on temporal and geographical aspects of projectile-point morphologies and their associated materials.

The earliest Archaic phase is defined by Weir (1976) as the San Geronimo Phase and is thought to encompass the period from about 5000 B.C. to about 3000 B.C. The phase is characterized by Bell, Uvalde, Martindale, and "Early Barbed" projectile-pointtypes. Burned-rock middens appeared late in the San Geronimo Phase (Weir 1976). Prewitt (1981a) has further divided Weir's phase into four phases based generally on single projectile-point types associated with discrete radiocarbon dates rather than on Weir's (1976) co-occumng types. Prewitt's (1981a) phases are, from earliest to latest, Circleville, San Geronimo, Jarrell, and Oakalla.

Following Weir's San Geronimo Phase is Weir's (1976) and Prewitt's (1981a)Clear Fork Phase, dating from about 3000 B.C. to 2000 B.C. This phase is characterized by Tortugas, Travis, Nolan, and Bulverde projectile-pointtypes. A recently defined type, La Jita, as described by Turner and Hester (1985), might fit into the Clear Fork scheme. This type bears certain affinities to the N olan/Travis tradition along the southeast edge of the Edwards Plateau (Turner and Hester 1985).

Two types of burned-rock middens can be identified with the Clear Fork Phase (Weir 1976): the typical oval mound (Weir's Type 1) and the less common circular aggregation of burned rocks containing a central pit (Weir's Type 2).

Weir's (1976) Round Rock Phase follows the Clear Fork Phase and dates from about 2000 B.C. to about 500 B.C. Characteristic of the Round Rock Phase are Pedernales, Langtry, and Val Verde projectile points. Type 1 burned-rock middens are also associated with the Round Rock Phase. Prewitt (198 1a) has divided the Round Rock Phase into the earlier Marshall Ford and the later Round Rock phases.

Following the Round Rock Phase is Weir's (1976) San Marcos Phase, dating from around 500 B.C. to A.D. 150. The phase is characterized by Lange, Castroville, Montell, Marshall, and Marcos projectile- 
point types. Three types of burned-rock middens are associated with the San Marcos Phase (Weir 1976): the common oval mound (Type 1), the circular aggregation containing a central pit (Type 2), and a pit excavated into the original ground surface surrounded by a crescent of rocks (Type 3). Prewitt (198 la) divides the San Marcos Phase into an earlier San Marcos and a later Uvalde Phase.

Following the San Marcos Phase is Weir's (1976) Twin Sisters Phase, dating from around A.D. 150 to A.D. 1250. Since Weir's time, the terminal date has been much in question and has been moved backward to around A.D. 500-700 (see, for example, Shafer 1971 and Prewitt 1981a). The Twin Sisters Phase is characterized by Ensor, Frio, and Darl projectile-point types, and Type 2 and Type 3 burned-rock middens (Weir 1976). Prewitt (1981a) has divided Weir's Twin Sisters Phase into an earlier Twin Sisters Phase and a later Driftwood Phase.

Numerous Archaic sites are known throughout the Central Texas Archaeological Region. Many are burnedrock midden sites and virtually all are multicomponent sites; that is, several of Weir's and Prewitt's phases are usually present at single sites. A brief sketch of a few of the excavated sites in the vicinity of $41 \mathrm{KM} 3$ is given below.

In eastern Kimble County, about 19 miles southwest of Site 41KM3, the SDHPT excavated a series of six Archaic sites along FM 479 near the James River (Young 1986). At Site 41KM61 materials from all of Weir's (1976) phases were recovered, but the greatest quantity represented the Round Rock (Pedernales and Bulverde dart points), San Marcos (Montell, Marshall, Castroville, Marcos, and Williams types), and Twin Sisters (Frio, Ensor, and Edgewood) phases. Two burned-rock middens seemed to be associated with the San Marcos and Twin Sisters materials, while no evidence was found to link the Round Rock Phase to either midden.

A second site, 41KM62, produced materials from every Archaic phase except San Geronimo, although the majority of the materials (Pedernales points) represented the Round Rock Phase. Burned-rock middens and a quantity of ground-stone artifacts were also present at the site (Young 1986).

A small campsite (41KE93) on the south bank of the Guadalupe River in Kendall County was also excavated by the SDHPT (Young 1987). This site produced artifacts from the Round Rock (Pedernales points), San Marcos (Castroville and Marshall), and Twin Sisters (Ensor) phases; but no burned-rock middens were present (Young 1987).

Site 41BT6, a terrace site near a tributary of the Colorado River in Burnet County, was excavated by the SDHPT in 1981 (Young 1985b). This site produced a small amount of material from the Clear Fork Phase (Nolan dart points) and a great majority of artifacts representing the Twin Sisters Phase (Fairland, Ensor, Frio, and Darl). A Type 4 midden (a single layer of scattered rocks) was thought to be associated with the Twin Sisters Phase (Young 1985b).

In Llano County, a burned-rock midden site (41LL78) on a terrace of the Llano River was excavated by the SDHPT (Patterson 1987). A few Late Paleoindian/Early Archaic (San Geronimo) artifacts (Angostura and Gower) were recovered, but the majority of the material recovered represented the San Marcos (Marcos and Castroville) and the Twin Sisters (Ensor, Fairland, Darl, and Frio) phases. Circular concentrations of rock clusters were interpreted as the remains of at least seven house structures, but temporal assignment of these features was not possible because of the compressed nature of the site deposits (Patterson 1987:113).

In Kerr County, the SDHPT excavated two burnedrock midden sites (41KR107 and 41KR109) in the Guadalupe River drainage (Luke 1980). These sites produced Late Paleoindian/Early Archaic artifacts (Angostura) and other artifacts characteristic of the San Geronimo Phase (Martindale and Bell). Numerous dart points representing the Clear Fork Phase ("Early Triangular," Nolan, and Travis) also were recovered and were thought to be associated with the middens (Luke 1980).

Another burned-rock midden site (Hop Hill) was excavated in Gillespie County by the University of Texas at San Antonio (Gunn and Mahula 1977). Virtually all Archaic phases were represented, but the phases that seemed to have been most prominent were the San Marcos and the Twin Sisters. The San Geronimo Phase was represented by the Martindale and Uvalde types; the Clear Fork Phase was represented by the Bulverde and Nolan types; the Round Rock Phase was represented by the Pedernales and Langtry types; the San Marcos Phase was represented by the Lange, Castroville, Marshall, and Montell types; and the Twin Sisters Phase was represented by Frio, Ensor, Wells, Darl, Yarbrough, and Fairland points. Based on an analysis of occupational floors, the authors hypothesized that the midden accrued basically during the Round Rock Phase and that subsequent occupations were coincidentally located atop the midden (Gunn and Mahula 1977:224).

In 1986 Creel undertook a study to determine the functional relationship of burned-rock middens to acorn processing (Creel 1986). Creel compared the distributions of live-oak savannah and burned-rock middens in west Central Texas and concluded that there was a meaningful correlation between them. He interpreted the data as indicating that acorns were being extensively used during the times that burned-rock middens were formed. In addition, he determined that Weir's Type 1 and Type 2 middens had similar 
distributions and therefore were both probably related to the use of acorns (Creel 1986:153).

The Archaic Period terminated around A.D. 700 (Prewitt 1981a). Hallmarks of the succeeding period, the Late Prehistoric, are the use of the bow and arrow, and pottery. It has been suggested (Prewitt 1981a) that the basic hunting and gathering subsistence strategies of the preceding Archaic Period continued much unchanged into the Late Prehistoric Period. The period has been divided into an earlier Austin Phase and a later Toyah Phase.

It is currently in vogue to drop the term "phase" when referring to the Austin interval because there do not now seem to be enough isolatable traits to define the interval as a "phase."

The Austin interval ended around A.D. 1200 (Prewitt 1981a) and is characterized by Scallorn, Edwards, and Granbury arrowpoints. The Toyah Phase is characterized by Perdiz and Cliffton arrowpoints, and terminated with the inception of the Historic Period around A.D. 1750 (Prewitt 1981a). The Historic Period itself was marked by the beginning of European contact, which ultimately brought about the demise of native cultures in the Central Texas Archaeological Region.

Late Prehistoric sites in the Central Texas Archaeological Region include the Smith Rockshelter in Travis County (Suhm 1957), the Kyle Site in Hill County (Jelks 1962), the Loeve-Fox Site in Williamson County (Prewitt 1981b), and the Rainey Site in Bandera County (Henderson m.s.).

At the Smith Rockshelter, a 9-in. sterile soil layer separated several feet of Austin-interval deposits from a single Toyah Phase deposit. Ceramics were present in the Toyah Phase component (Suhm 1957).

At the Kyle Site, Jelks was able to compile a list of culture traits unique to each Late Prehistoric phase or interval as the result of unquestionable separation between the Austin interval and the Toyah Phase (Jelks 1962). He postulated that, in addition to Scallorn and Granbury arrowpoints, only the Austin interval contained dart points, Friday knives, and serrated flakes. Similarly, he concluded that only the Toyah Phase contained Perdiz and Cliffton arrowpoints, Covington knives, double-pointed and four-edged beveled knives, small drills, snub-nosed end scrapers, bison bone, and pottery (Jelks 1962). Radiocarbon dates at the Kyle Site placed the Austin interval between A.D. 411 and A.D. 951, and the Toyah Phase between A.D. 1131 and A.D. 1691 (Jelks 1962).

At Loeve-Fox, Prewitt was able to factor out additional traits unique to each Late Prehistoric phase or interval (Prewitt 1981b). The Austin interval produced large basin-shaped hearths, burned clay/charcoal pits, and marine-shell ornaments. The Toyah Phase produced plano-convex end scrapers, Leon Plain ceramics, and large flat hearths. Prewitt dated the Austininterval at A.D. 700 to A.D. 1300, and the Toyah Phase at A.D. 1300 to A.D. 1750 .

The Rainey Site produced a stratified sequence of transitional Archaic/early Late Prehistoric, Early Austin, Late Austin, Early Toyah, and Late Toyah occupations (Henderson m.s.). Within this sequence, the Edwards type was found to underlie all other previously established Late Prehistoric types, and the Sabinal type was placed firmly within the Late Austin interval. Perdiz points and bison bone were recovered exclusively from the Toyah Phase strata. A wide selection of radiocarbon dates placed the transitional Archaiclearly Late Prehistoric occupation between A.D. 560 and A.D. 710, the Early Austin interval between A.D. 940 and A.D. 1030, and the Late Austin interval between A.D. 990 and A. D. 1140 (Henderson m.s.). The Early Toyah Phase was radiocarbon-dated at A.D. 1190 to A.D. 1250 (Henderson m.s.).

A frequent occurrence in the Central Texas Archaeological Region is the presence of Austin and Toyah materials atop burned-rock middens of presumably earlier age. This phenomenon was noted at many of the Archaic sites discussed above. At Site 41KM61, a Toyah Phase occupation was present atop the midden occupations, and at Site 41KM62, Leon Plain ceramics and unclassified arrowpoints were also present (Young 1986).

At Site 41BT6, Austin-interval materials (Scallorn) and Toyah Phase materials (Perdiz) were recovered in association with a Type 4 midden (Young 1985b). At Site 41LL78, the Austin and Toyah phases were represented by Scallorn, Alba, Cliffton, and Perdiz arrowpoints, and Leon Plain pottery (Patterson 1987). At Hop Hill, Fresno, Cuney, Perdiz, Scallorn, Young, and Edwards arrowpoints were recovered (Gunn and Mahula 1977).

At least two sites are known where arrowpoints have been recovered from deep within the internal structures of two burned-rock middens and are presumed to have been directly associated with the accretion of the middens. The first site is 41UV86 in Uvalde County, excavated by the SDHPT in 1982 (Goode m.s.). The second site is $41 \mathrm{MS} 32$ in Mason County, just 15 miles or so east of 4IKM3, excavated by the SDHPT in 1988 (Goode 1988). The middens at both sites contained intact internal ovens or hearths, and association with Late Prehistoric arrowpoints indicates that the middens were formed during the Late Prehistoric Period. 


\section{Testing Procedures}

The centerline for FM 3480, with a bearing of N 83" $17^{\prime} 15^{\prime \prime} \mathrm{E}$, was used as the east-west base line for the archeological grid. The N0/E0 coordinate was established at a point of intersection on the centerline at Station $81+65.94$. This point was near the west end of the site, on the south side of the road, in an old private ranch-road entrance (Fig. 2).

Vertical control was maintained through reference to two established SDHPT bench marks: one near the west end of the site (elevation $482.34 \mathrm{~m}$ above mean sea level) and one near the east end (Bench Mark No. 8, elevation $480.90 \mathrm{~m}$ above mean sea level). The western bench mark was outside the revised right-of-way at some distance from the excavation area; therefore, a more convenient datum (elevation $481.11 \mathrm{~m}$ above mean sea level) was established from the original bench mark, located within the right-of-way nearer the excavations.

Efforts were concentrated in two main areas of the site: the western end near the Red Creek crossing and the eastern end near RM 385. These areas were about $200 \mathrm{~m}$ apart on the south side of the county road. They were situated along portions of the terrace slope where the degree of slope was more gradual. Between these two areas, the terrain was more rugged and the slope more severe, the topography dropped off drastically toward the creek, and in situ archeological evidence was not observed.

Four backhoe trenches were placed in the two excavation areas - two in the west end and two in the east end (Fig. 2A, B). The trenches were oriented perpendicular to the slope and to the county road in order to sample a cross section of the deposits from the county road to the south right-of-way line. The depth of each trench varied, but bedrock was reached in every trench.

In the west end, a dense motte of scrub cedar, oak, brush, brambles, and low ground-cover was present atop the area to be tested. This area was cleared of vegetation by hand with chain saws, machetes, and other small tools, prior to excavation. The NO/E 0 coordinate was established in this area and four $2 \times 2-m$ test units were excavated by hand (Fig. 2A). Three units were situated atop an area where a concentration of burned rocks was present on the surface, and one unit was placed near the southern right-of-way line in an attempt to define the site boundary.

The grid used in the west area was extended to the east end of the project. In the east area, nine 2 x 2-m test units were situated in areas displaying surface

concentrations of burned rocks and flint debris (Fig. 2B). Three additional $1 \times 1-\mathrm{m}$ units were abutted to one of the 2 $\mathrm{x}$ 2-m units in this area in order to completely expose a feature.

A single $1 \times 1-m$ unit was excavated on the north side of the county road as a special test to determine the internal integrity of a burned-rock feature eroding from the backslope of the existing county road cut. This unit was excavated in two 10-cm levels until the top of an intact buried midden was exposed, at which time testing at this locale was halted in lieu of the avoidancelprotection plan proposed for site deposits on the north side of the road.

All other units were excavated in 10-cm levels until the caliche gravels and cobbles overlying bedrock were reached. In the west area, these bedrock gravels were encountered in Level 1 in three of the four units; the remaining unit was taken to Level 4. In the east area, indications of bedrock were encountered in Level 2 in ten units, Level 4 in one unit, and Level 5 in one unit. In three of the units in the east area and one in the west area, once the bedrock gravels were reached, half the unit was excavated one $10-\mathrm{cm}$ level further into the gravels to test for materials that might have worked their way downward into the gravels from overlying cultural deposits. A small amount of additional flake debitage was recovered in this way from within the gravel deposits.

All soil was passed through 114-in. mesh hardware cloth. Recovered materials from each level of each unit were placed in appropriately labeled bags and returned to the SDHPT Archaeology Lab in Austin, Texas, for processing and analysis.

Soil samples were collected from within features, and charcoal samples were collected whenever encountered in undisturbed contexts. Scale drawings, a daily journal, and a photographic record were maintained throughout the project.

Also, throughout the project, a continual general surface collection was conducted within the right-of-way, and recovered materials were bagged according to provenience relative to the nearest grid coordinate. A site map was generated using an alidade and plane table. This map was confined to the portions of the site within and immediately adjacent to the right-of-way; the northern portion of the site was not mapped. The map is reproduced herein as Figure 2. 


\section{Features}

A total of 11 features were recorded during fieldwork at Site 41KM3. Of these, five features (Features 1 through 5) were north of the county road (Fig. 2) and thus destined for avoidancelpreservationrather than excavation. Except for a brief exploration of Feature 3, these features were not investigated during testing of the site.

An additional two features (Features 8 and 11) were present within the existing roadbed (Fig. 2). These features were not excavated because excavation would have required closing the county road to through traffic, a procedure which was not deemed feasible since neither feature appeared to be intact. Only what appeared to be the bottom remnant of an in situ hearth remained of one feature (Feature 8), and the other feature (Feature 11) was what appeared to be the displaced remains of a disturbed hearth.

The remaining four features (Features 6, 7,9, and 10) were encountered and documented during testing of the south side of the new right-of-way (Fig. 2A, B).

\section{Burned-Rock Middens}

\section{Feature 3}

At the time of initial investigation, Feature 3 was a more-or-less linear array of burned rocks eroding horizontally from the backslope of the road cut along the north side of the county road (Figs. 2 and 7A). The exposure was in a cut about $30 \mathrm{~cm}$ or so below the present-day ground surface and extended for about $3 \mathrm{~m}$ east to west along the backslope. The rocks appeared to represent a buried feature that had been cut into and exposed during previous county-road construction activities. Additional burned rocks were seen scattered along and eroding from the road cut at the same elevation, suggesting a buried occupational surface at that level.

Mixed among the burned rocks were flint flakes, mussel shell fragments, a Pedemales dart point, and historic debris. Some of this material was loosely resting atop grass and leaves, indicating that it represented secondary deposition, while some of the material appeared to be protruding upward from an in situ subsurface position, indicating that it representedintact buried deposits and/or features.

A single $1 \times 1$-m test unit, not aligned with the site grid, was sunk into Feature 3 in order to determine whether the surficial burned rocks were eroding from an intact buried feature at that locality or whether the rocks simply had washed downslope to their present position from somewhere higher up on the terrace. If they had proved to represent an intact buried feature, then an effort would have been implemented to protect the feature in place; if they had proved to simply represent slopewash, then their presence would have been recorded, but no further work would have been done.

The test unit revealed a buried feature that completely covered the floor of the $1 \times 1-\mathrm{m}$ unit at the $20-\mathrm{cm}$ level (Fig. 8). The feature extended subsurface in all directions and appeared to be the top of an intact burned-rock midden. It had a mounded appearance rather than being flat or basin shaped. Testing was halted as soon as the determination was made that buried portions of the feature were intact, and the feature was included within the preservation plan.

\section{Feature 4}

Feature 4 was a small burned-rock midden, about 10 $\mathrm{m}$ in diameter, located partially within the right-of-way on the north side of the road (Figs. 2 and 9 ). About $2 / 3$ of the midden extended outside the right-of-way to the north. The southern edge of the midden had been truncated by the original county-road construction, and the midden was approximately $15 \mathrm{~cm}$ thick at that cut. It was thicker toward its center, approximately $5 \mathrm{~m}$ away.

A modem post hole had been dug into the midden along the new right-of-way line, approximately $3 \mathrm{~m}$ southeast of the midden's crest, and this hole revealed a midden thickness of about $15-20 \mathrm{~cm}$ at that point. The post hole revealed that most of the midden was buried, with only a single layer of scattered midden rocks showing on the surface.

A Side-Notched dart-point fragment similar to La Jita type was recovered from the backdirt from the post hole. On the surface, the midden was surrounded by random burned rocks, flint tools, debitage, and mussel-shell fragments.

Feature 4 was the most intact of any of the surface features observed at Site 41KM3. It had suffered no disturbancefrom the artificial terracing that took place to the north, and it had not been severely damaged by erosion, looting, animal activities, or previous construction. Since current road work was being planned to avoid the feature, it seemed desirable to try to protect/ preserve the feature in place rather than to excavate it. Therefore, the feature "will be protected by an earthen embankment along the existing road cut, on top of which will be placed an earthen dike 14' wide and 24" thick" (SDHPT 1988). 

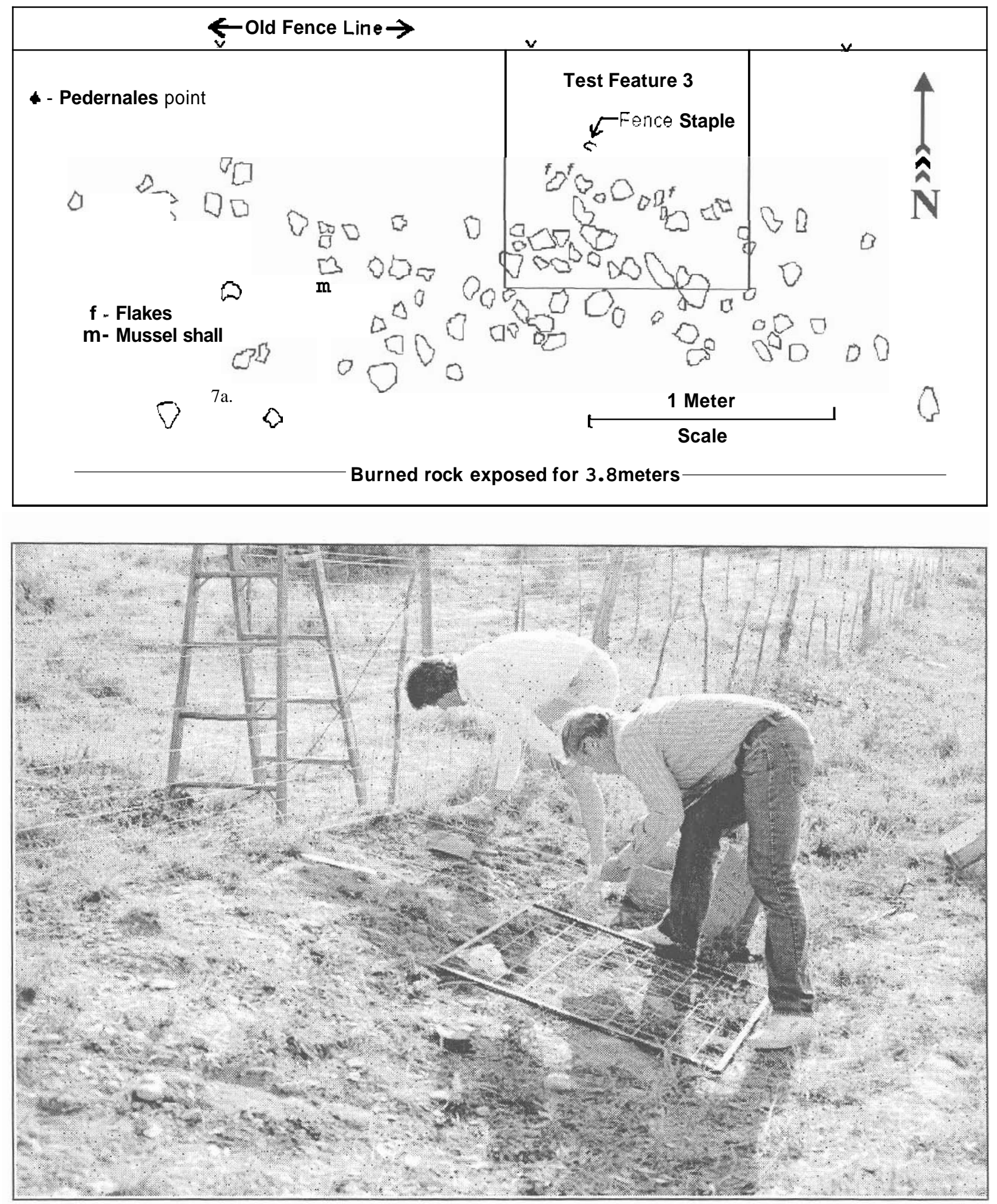

FIGURE 7. Feature 3. A (top), surface plotting of Feature 3 before testing: B (bottom), crew exposing Feature 3. 

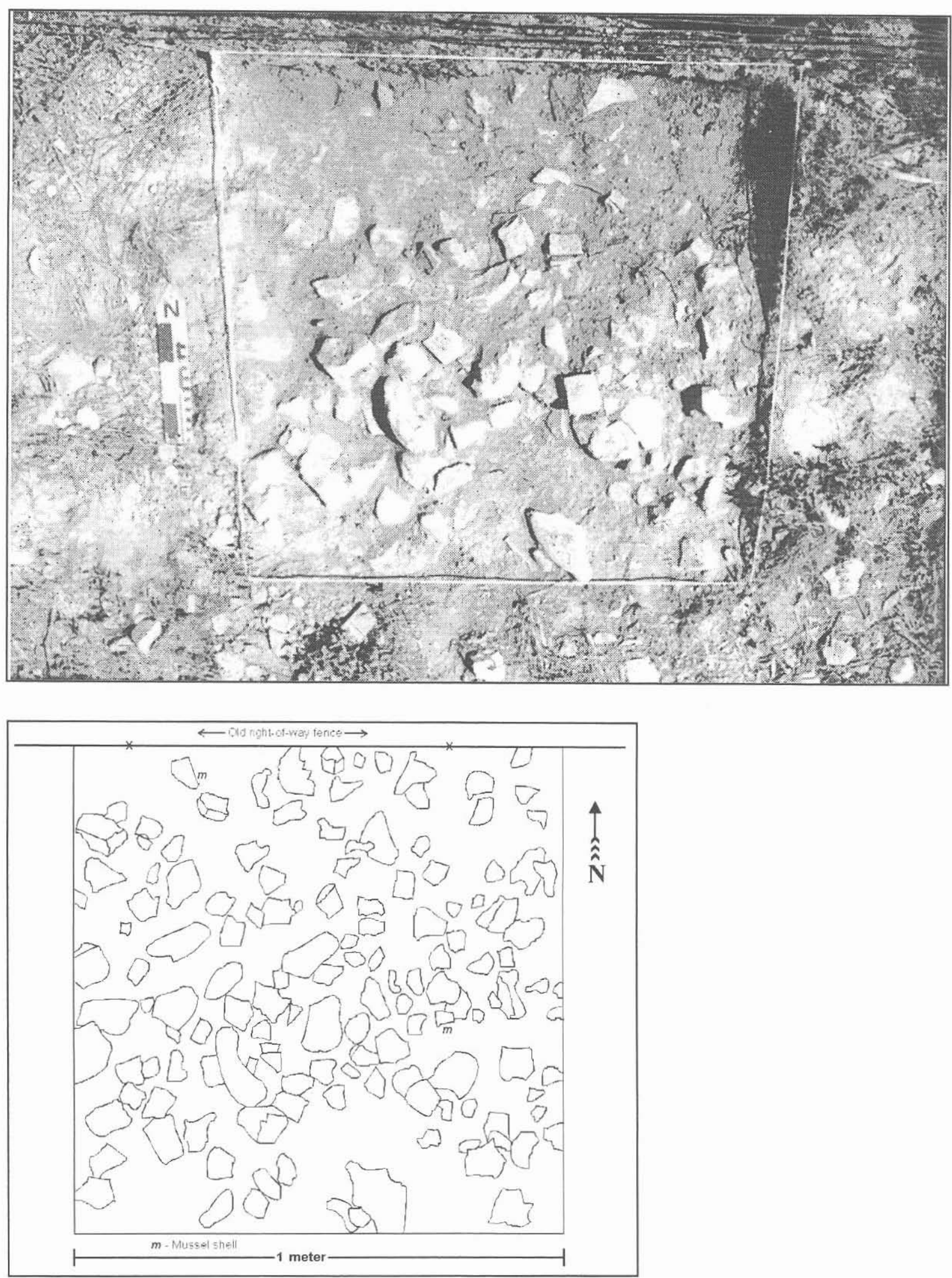

FIGURE 8. Feature 3 as exposed in test unit. A (top), photograph of top of feature; B (bottom), plan view of top of feature. 


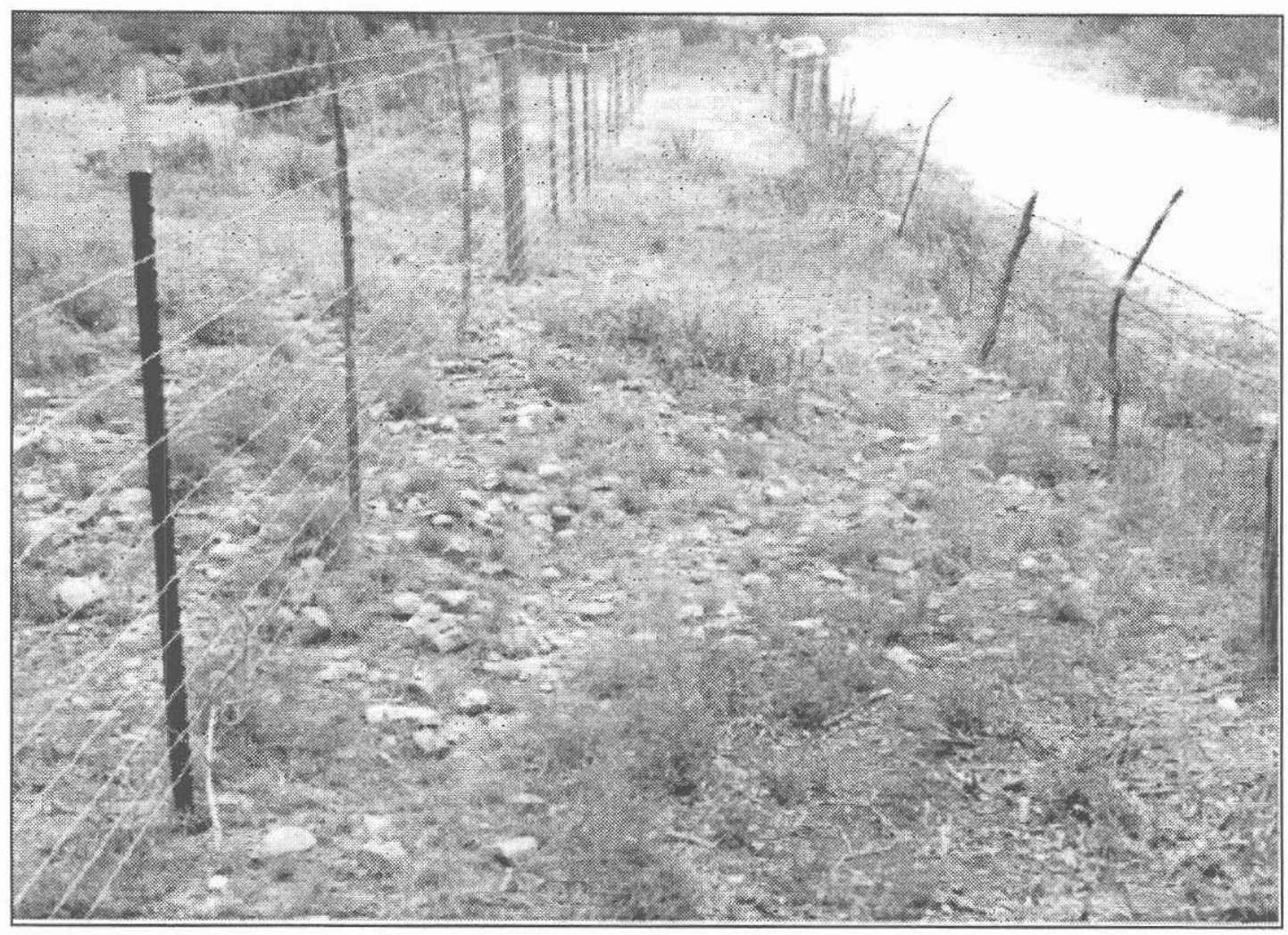

FIGURE 9. Feature 4. looking east. County fence line is on the right; new right-of-way fence is on the left.

\section{Feature 5}

Located just $7 \mathrm{~m}$ to the west of Feature 4 (Fig. 2). Feature 5 was a small (2-3 $\mathrm{m}$ in diameter) incipient midden (Fig. 10), satellite to the larger Feature 4. Feature 5 rose only about $10 \mathrm{~cm}$ above the modem ground surface and its depth subsurface was undocumented. About 1/3 of Feature 5 was in the right-of-way of FM 3480, with the remaining 2/3 or so extending northward onto private property.

Near the feature's center, an animal disturbance was present that had displaced a number of burned rocks and associated flint flakes in a small area about $20 \mathrm{~cm}$ in diameter and $10 \mathrm{~cm}$ deep. The disturbance was minimal and did not seem to have destroyed the overall shape or size of the midden; it did indicate, however, that intact buried portions of the feature were still present. Scattered about the periphery of Feature 5 was an abundance of burned rocks and flint debris. The small midden seemed to have shared a direct relationship with the larger midden, Feature 4. It, like the larger midden, was destined for protection/preservation.

\section{Undocumented Midden}

According to local informants, the largest midden at the site had already been destroyed prior to the present project. This midden, reportedly a meter or more in height and $15-20 \mathrm{~m}$ in diameter, is said to have existed totally within the alignment of what became the county road and was removed when the road was built.

The midden is said to have been located somewhere in the vicinity of Features $\mathbf{8}$ and 11 near the eastern end of the project (Fig. 2). An examination of the roadbed in this area revealed no evidence of a midden remnant; however, an abundance of random burned rocks and flint debris in this area may represent the scattered remains of the midden's contents or other materials associated with that feature's activities. A Pedernales dart point, as well as other lithic tools, were found embedded in the roadbed in the vicinity of the purported midden. 


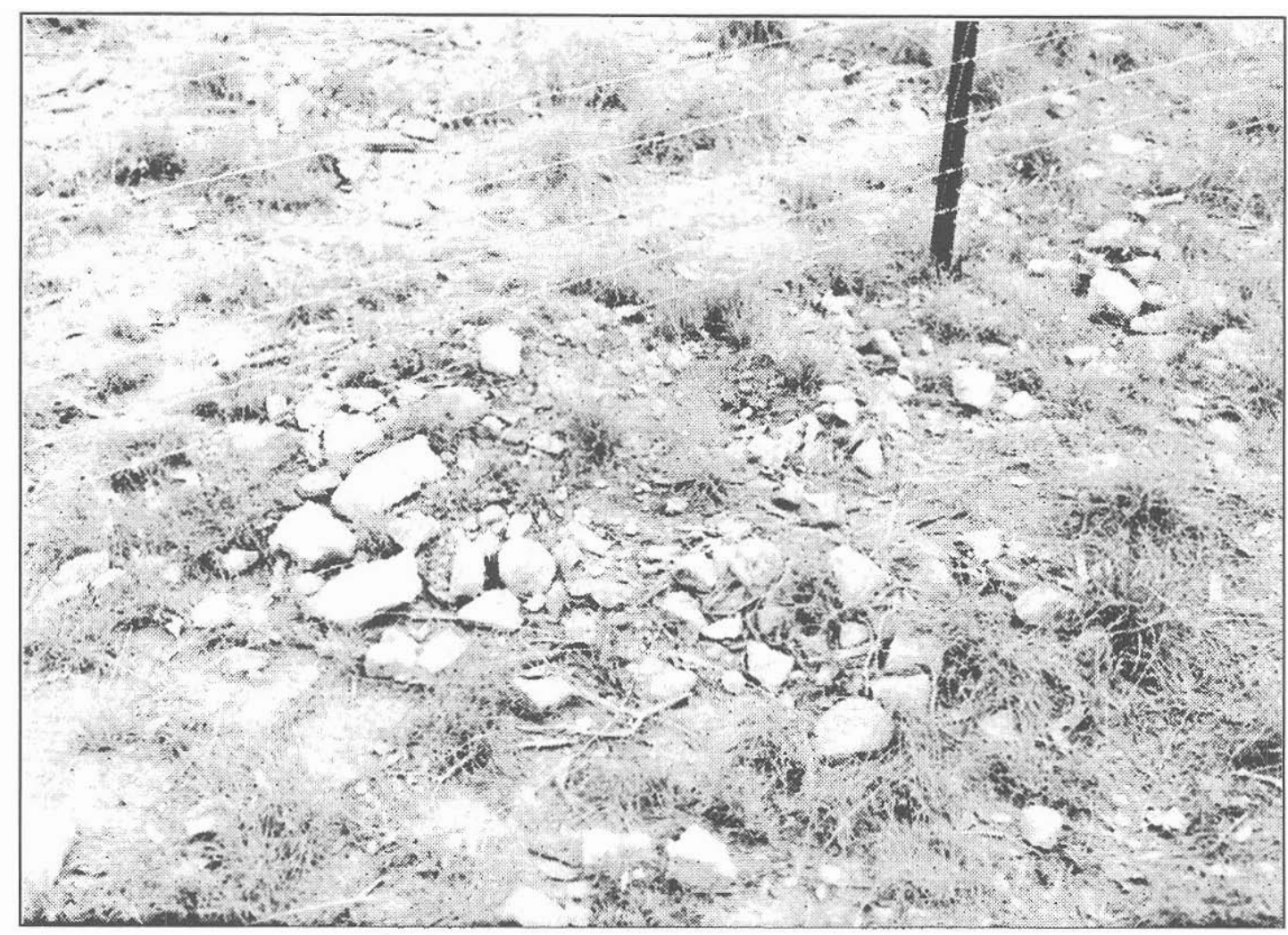

FIGURE 10. Feature 5

\section{Hearths}

\section{Feature 1}

Feature 1 was a presumed hearth located partially within the right-of-way on the north side of the county road at the west end of the site (Fig. 2). The north rightof-way line bisected an exposed concentration of burned limestone rocks that appeared to only partially represent a complete feature. The feature was mostly buried about 20 $\mathrm{cm}$ below the ground surface and was eroding from the west hackslope of a private ranch-road entrance. The ranch road had been cut northward into the terrace from the county road in order to gain access to the terrace top from the lower elevations in the low-water crossing area. This road cut had extended through the cultural deposits into the bedrock gravels, and Feature 1 was truncated by that cut.

The exposed portions of Feature 1 consisted of burned rocks ranging from small to medium-cobble size, some of which were eroding down the slope along the west side of the ranch road. What appeared to be additional in situ hearthstones protruded from a subsurface position at the same locality.

The size of the feature is unknown; the feature was not investigated archeologically because it was destined for protection/preservation. It appeared to lie at the same level as Feature 3 and possibly represented the same occupation or living surface.

The soil among the in situ hearthstones was noticeably darker and ashier than the surrounding deposits. There was an abundance of flint flakes in the vicinity of the feature, many of which were highly patinated. In general, the degree of patination on the flint debris in this area of the site (near the west end) was markedly more pronounced than that seen on flint in other areas of the site.

A post hole had been dug into Feature 1 in preparation for laying the new right-of-way fence line. This hole revealed a feature thickness of about $15 \mathrm{~cm}$. The backdirt from the post hole contained dark ashy soil, burned rocks, flint flakes, and mussel-shell fragments. 


\section{Feature 2}

Feature 2 (Fig. 2) was only cursorily examined because it lay outside the project right-of-way. It consisted of an irregular flat circle of rocks, approximately $2 \mathrm{~m}$ in diameter and void of rocks in the center. The rocks forming the circle were not entirely contiguous and it was not determined whether they were burned or not. Most were large cobbles some $20 \mathrm{~cm}$ or so in diameter; and only the tops of many were exposed, suggesting that perhaps others were present but not visible because they were buried beneath the surface. Some of the rocks rested atop grass or other vegetation, indicating that they had been displaced.

The center of the circle formed by these rocks was filled with soil not unlike the rest of the soil on-site, and there was no indication of additional rocks or internal burning in the central portion of the feature. Sparse vegetation was growing both inside and outside the circle of rocks, with no evidence of differential growth.

There was no opportunity to explore this feature further since it was located outside the right-of-way, so any comments regarding possible function of this feature, its contents, or its interpretation would be speculative. Even so, the feature seemed to have superficial similarities to Feature 7, to be discussed later, and it is tempting to suggest that the two features may have been analogous.

\section{Feature 6}

Feature 6 was exposed and documented during archeological testing of the site. It was first noted as an east-west linear exposure of burned rocks along the southern backslope of the county road cut in the west excavation area (Fig. 2A). The feature occurred in an area where repeated blading of the road had cut into, as well as pushed materials atop of, the natural deposits, thereby obscuring the original integrity of the deposits.

A number of historic artifacts, including tin cans, broken glass, nails, household garbage, and other recent debris had been tossed on top of the feature and subsequently been buried. In addition, recent burning of trash and other debris in the vicinity had further obscured the integrity of Feature 6. So it was not readily detectable whether the surface manifestations indicated a buried prehistoric feature at that locality, or whether they were simply disturbances and secondary deposition of materials displaced from elsewhere along the roadway.

Excavation revealed that an intact hearth (Feature 6), with some displaced hearthstones, did indeed exist immediately beneath the surface rubble in Units $\mathrm{N} 1 / \mathrm{W} 4$, N 1/W 6 and N 1/W 8, Level 1 (Fig. 11A,B). The hearth measured $1 \mathrm{~m}$ east-west by $1.20 \mathrm{~m}$ north-south and was one layer of rocks thick. Hearthstones had been scattered westward, presumably from county-road maintenance activities, for a distance of about $3 \mathrm{~m}$. Apparently a blading machine had scraped the uppermost rocks toward the west and scattered them in a linear array away from the hearth.

A circular area void of hearthstones was present in the central-southeastern portion of the hearth, and possibly some of the scattered stones had been displaced from this area. Among the scattered burned rocks were flint flakes, numerous tin cans, broken glass, historic ceramic sherds, nails, and charcoal that apparently had been scraped along the county-road edge. In some cases the historic material was underlying the burned rocks.

A circular burned area measuring almost $1 \mathrm{~m}$ in diameter was present about $2 \mathrm{~m}$ west of the hearth (Fig. 11B). The soil in this area had the loose consistency of recent intrusive material, and apparently had been pushed onto its present position and then burned, along with the large quantity of historic trash. Large chunks of charcoal and partially burned materials were present in this area, but none of the charcoal was collected for radiocarbon dating because of its dubious affiliation.

Several flat, slab-like rocks were present along the southern portion of the hearth and appeared to be in place, while the rocks in the northern portion were jumbled atop each other and appeared to be slightly displaced. Many of the rocks were fractured from heat, but were still in place. The outer rocks comprising the perimeter of the original hearth appeared to have been preserved in place, while the central portion of the hearth seemed to have suffered the most disturbance.

Perhaps the hearth was originally mounded highest in the center and, therefore, those highest central rocks were the ones that were struck and displaced when the area was bladed. The intact portions of the hearth did not display a basin shape, but rather the bottom of the hearth was flat and conformed to the original prehistoric ground surface. The hearth thus appeared to have been constructed on a flat ground surface, without initial preparation of that surface.

No diagnostic artifacts were associated with Feature 6. A small, crudely made biface was found northeast of the hearth at a slightly higher elevation in a disturbed context. This tool appeared to have been pushed there amid intrusive material during county scraping activities and therefore may not have been directly associated with the hearth itself.

In summary, the hearth appeared to have been a flat, circular structure composed of flat, slab-like rocks covering an area about $\mathbf{1} \mathrm{m}$ in diameter. The structure was one layer of rocks thick, but may have been slightly mounded originally.

The hearth was on the extreme southwest periphery of the site, downslope toward the creek from the main site 

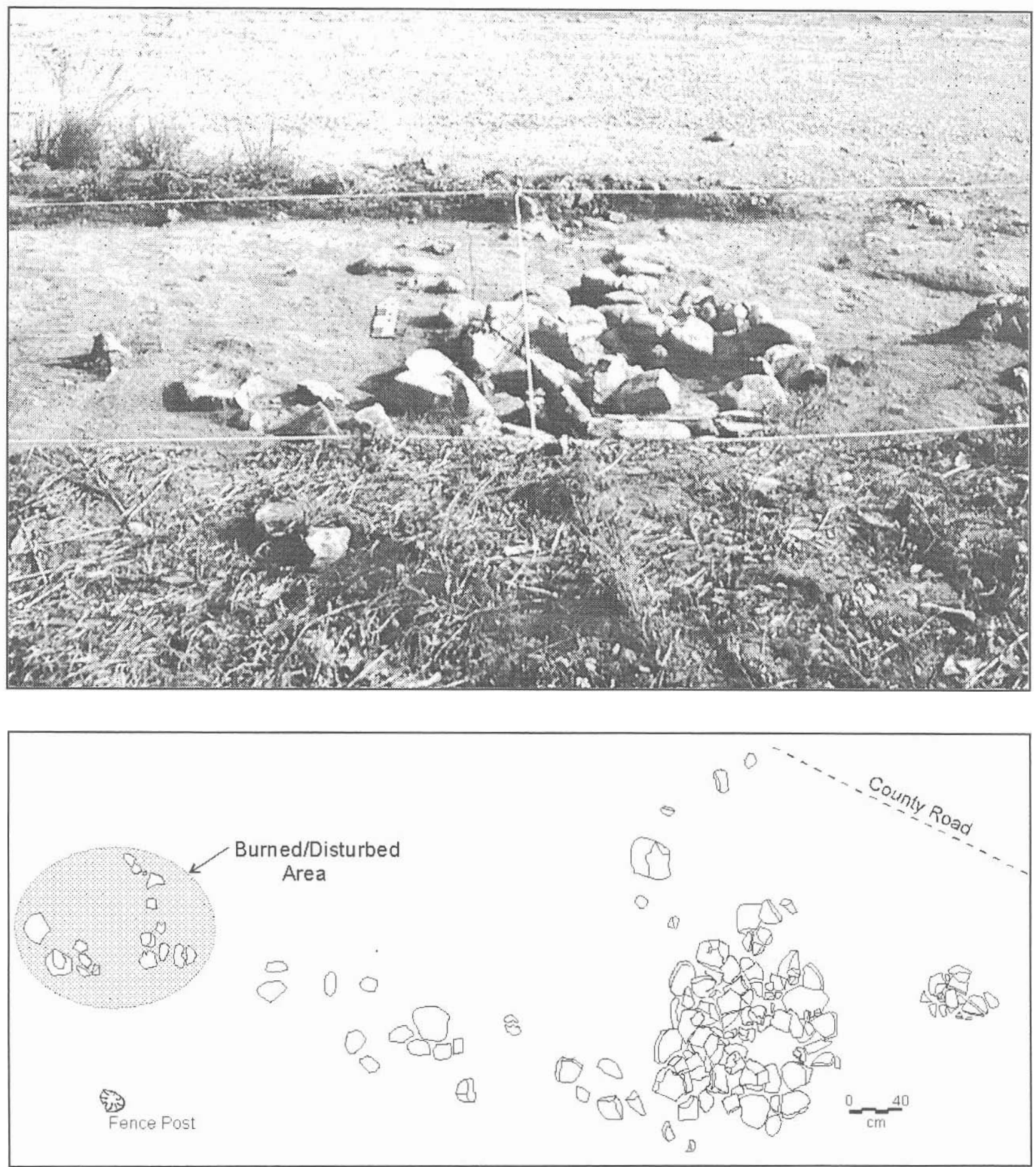

FIGURE 11, Feature 6. A (top), photo of exposed intact portion of feature, looking north: B (bottom), plan drawing. Note county road north of Feature 6 in photo. 
area. Its elevation was only slightly higher than the area just 4 or $5 \mathrm{~m}$ to the southwest that contained recent flooddeposited soil (Fig. 6). Red Creek is about $30 \mathrm{~m}$ to the south and west of the Feature 6 locality and obviously has flooded to within a few meters of the hearth many times in the past. The hearth itself rested on a floor of mixed soil and bedrock gravels, and no further soil zones or cultural materials existed beneath this floor.

\section{Feature 7}

Feature 7 was a large, basin-shaped hearth on the south side of the road in the east excavation area (Fig. 2B). It measured $1.75 \mathrm{~m}$ east-west by $1.70 \mathrm{~m}$ north-south (Fig. 12), and there was a differential of $15 \mathrm{~cm}$ or more in elevation between the outer rocks and the center of the hearth (Fig. 13). The top of the hearth's perimeter was encountered in Level $1(0-10 \mathrm{~cm})$, but the bottom of the hearth was not completely exposed until Level 3 (20-30 $\mathrm{cm}$ ) had been excavated. Initially encountered in Unit S2/ E223 (a standard $2 \times 2-m$ unit), the feature extended northward and westward. Excavation of three additional 1 x 1-munits (Units S0/E222, S0/E221, and S1/E221) was necessary to completely expose the feature.

The hearth was almost totally intact. A fence post had been driven into the southeast portion of the hearth, displacing the hearthstones in the vicinity of the post, but causing minimal damage. The post was part of the fence line marking the south right-of-way of the original county road. Roots from several small mesquite trees in the vicinity of the hearth had intertwined among the hearthstones, but had caused very little displacement.

Maintenance of the county road had not disturbed the hearth, but had pushed soil from the roadway atop it. This soil, although containing artifactual material, was easily discernible from the hearth fill because of a dramatic change in color and texture. The hearth fill was a darkgray powdery silt, a result of its high ash content, as opposed to the light reddish tan loam of the intrusive soil.

The dark ashy soil was contained within the hearth basin and was present among and beneath the hearthstones. The light reddish tan soil was piled atop the dark-stained soil of the hearth basin and atop the hearth itself, and averaged $5 \mathrm{~cm}$ in thickness. Among and beneath the hearthstones was an abundance of wood charcoal, some in chunks as large as $5 \mathrm{~cm}$ in diameter. The soil was burned beneath the hearth to a depth of 15 $\mathrm{cm}$ in places.

The hearthstones, for the most part, appeared to have been selectively placed in position to abut adjacent hearthstones. Although the stones appeared to have been purposefully laid in this manner, there remained gaps between some of the rocks where no rocks were present. Individual rocks, in general, were not selected and positioned so that their orientation would produce a downward slant to form the basin; rather, the rocks were round cobbles, placed on a slanted surface so that the orientation of the rock-lined surface itself slanted downward to form the basin. In other words, the basin was created by an excavated surface lined with rocks, rather than by the shape and orientation of the rocks themselves (Fig. 13B).

The abundance of charcoal in the intervening space between the burned rocks that lined the basin and the excavated bottom of the basin led to the conclusion that the wood for the fire had been placed in the basin before the rocks were added. The fire must have been fairly large to have occupied such a large space and to have created such a quantity of charcoal.

Many of the rocks had been heat-fractured and remained in place, while others appeared to have been fractured and then repositioned - perhaps even recycled from other hearths. Individual hearthstones averaged about medium-cobble size.

In addition to charcoal, contents of the feature included flint flakes and mussel-shell fragments. A Pedernales dart point was found on the screen amid soil excavated from atop the hearth, just at the juncture of the overburden soil with the feature fill. The artifact was not observed in situ, so a determination could not be made whether the dart point was actually part of the feature fill or intrusive to the feature. Either way, the dart point and the feature both were probably of comparable age, since the soil comprising the overburden was scraped up from surfaces adjacent to and at the same elevation as the feature.

Feature 7 was excavated aboriginally into older culture-bearing deposits that ultimately rested atop bedrock gravels some 15-20 cm deeper than Feature 7. Borrow material from the excavated basin was not recognized in the archeologicalexcavations and no doubt created some mixing of archeological materials at the Feature 7 level. A fair amount of additional mixing caused by erosion and sheetwashing across the site was also observed and was demonstrated in the disparate ages of various dart-point types recovered from the same context.

Feature 7 was situated near the southeast periphery of the site (Fig. 2). The terrace edge was present about 6-8 $\mathrm{m}$ farther south and was fairly precipitous there, creating a natural boundary to the site in that area. However, human activity appears to have been fairly heavy in the southeast area of the site, judging from the amount of flint debris, burned rocks, and hearths in the area. The unconfirmed destroyed midden also was purported to have been present in this area. Several Archaic dart points were recovered from the surface in the vicinity of Feature 7. 

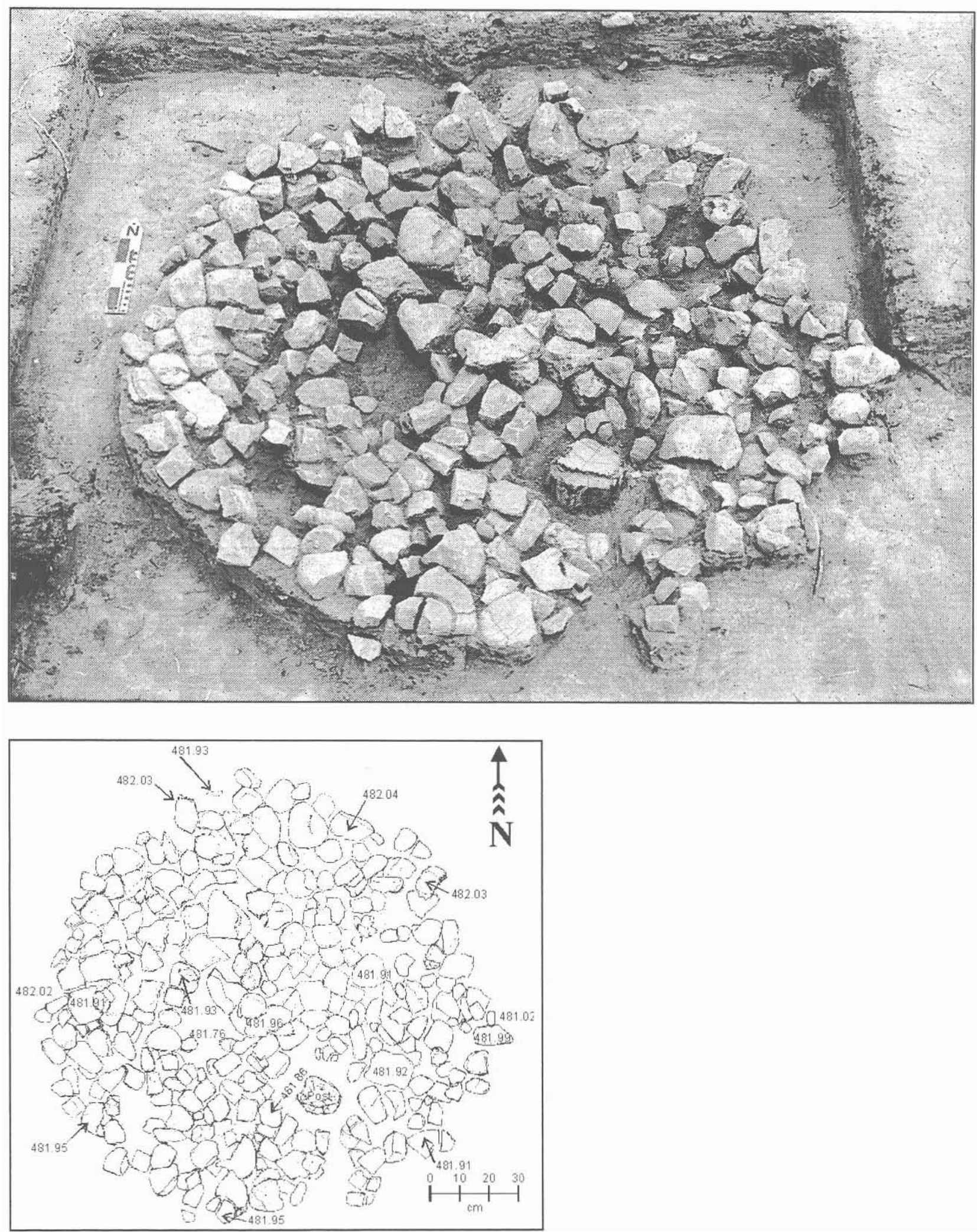

FIGURE 12. Feature7. A (top), photo of exposed feature; B (bottom), plan drawing. 

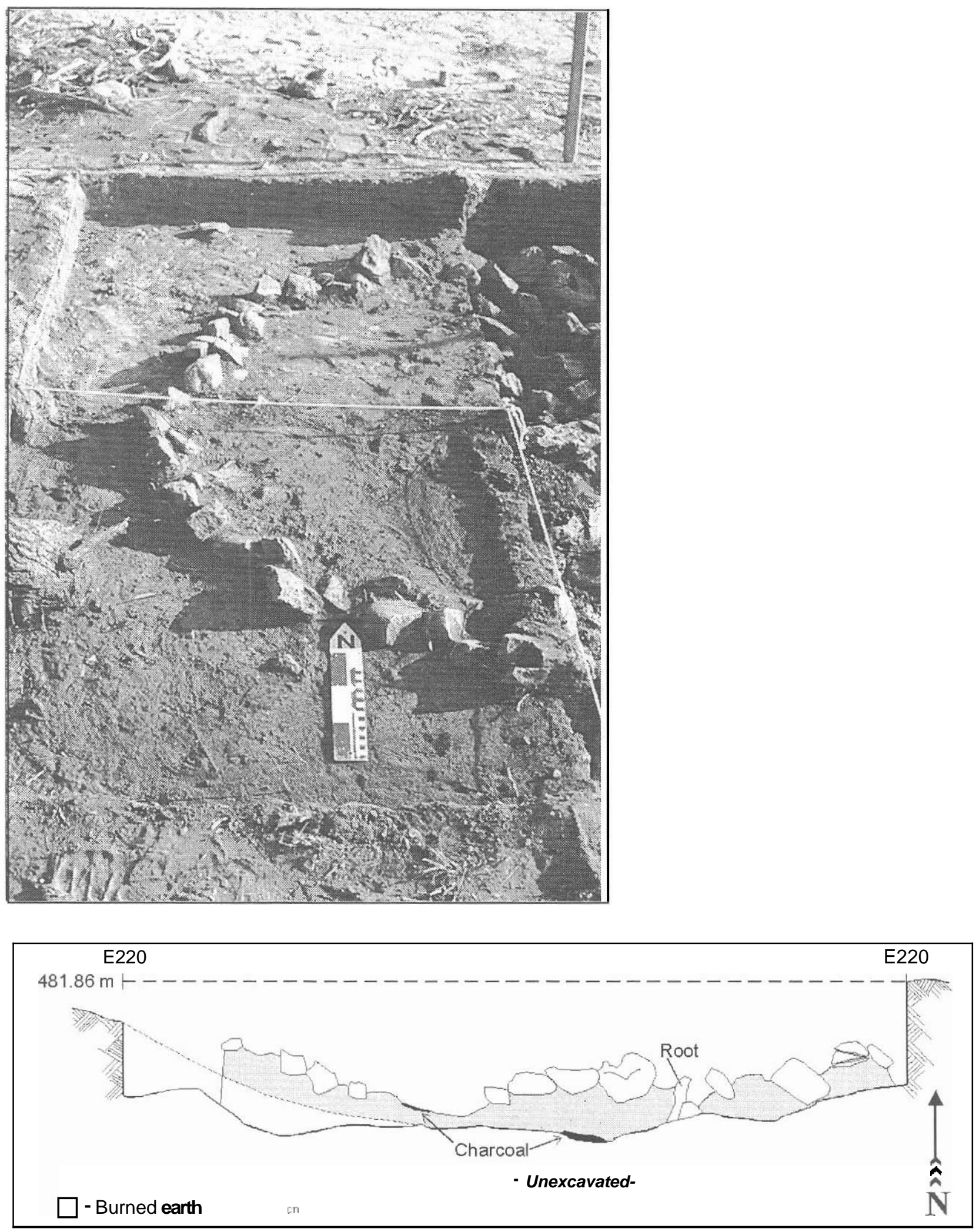

FIGURE 13. Feature 7. A (top), photo of west half of Feature 7 at Level 1; B (bottom), drawing of feature in cross section. 


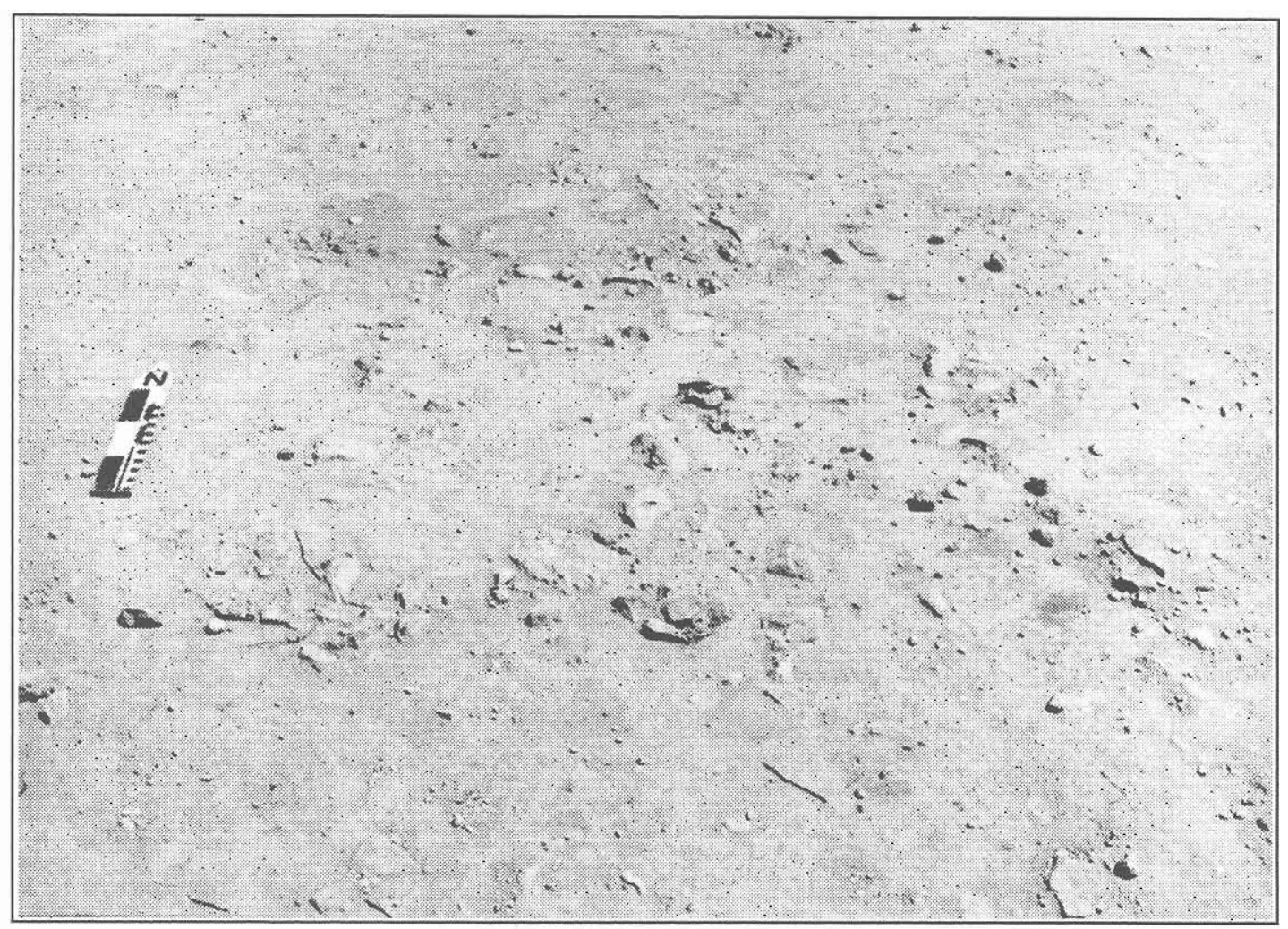

FIGURE 14. Feature 8, looking north

\section{Features 8 and 11}

Features 8 and 11 were situated within the existing roadbed of the county road (Fig. 2B); they were not excavated for that reason. Both features appeared to he the remains of hearths that were located in the pathway of the original county road and were severely damaged as a result of construction of that road. It appeared that the top portions of both features were removed in order to level the road, and only their bottommost portions remained in the existing roadbed to attest to their former existence. Repeated blading and vehicular traffic on the road further damaged these features.

Feature 8 appeared to be the bottom portion of a circular hearth, with scattered burned rocks to the south (Fig. 14). The circular portion measured approximately 1 $\mathrm{m}$ in diameter and consisted of highly fractured and sometimes pulverized burned rocks.

The hearthstones seemed to he in situ and to represent the locality of a hearth that appeared to have been originally similar to Feature 7. Feature 8 was about $17 \mathrm{~m}$ east-northeast of the Feature 7 locality and was of comparable elevation. It therefore might have been related to Feature 7 in function and age.
Feature 11 was an accumulation of burned rocks about $5 \mathrm{~m}$ east-northeast of Feature 8. The rocks occurred in an area about 1.5-2 $\mathrm{m}$ in diameter, but were not densely concentrated within that area. Rather, they formed a sparse accumulation that appeared to be the disturbed remains of a hearth. They did not appear to be in situ so much as to be scattered about from a hearth locus somewhere in the vicinity. Feature 11 was at approximately the same elevation as Features 7 and 8 and so might have been related.

Scattered about the surface of the county road, in the vicinity of and at the same elevation as Features 8 and 11, were additional burned rocks and an abundance of flint debris, including some tools. A Pedernales dart point was recovered from the road surface near Feature 8 . It is not known whether these materials were in situ, lying just deep enough to have been spared the damaging blade, or had come to rest at their present position as a result of having been scraped up from somewhere else. 


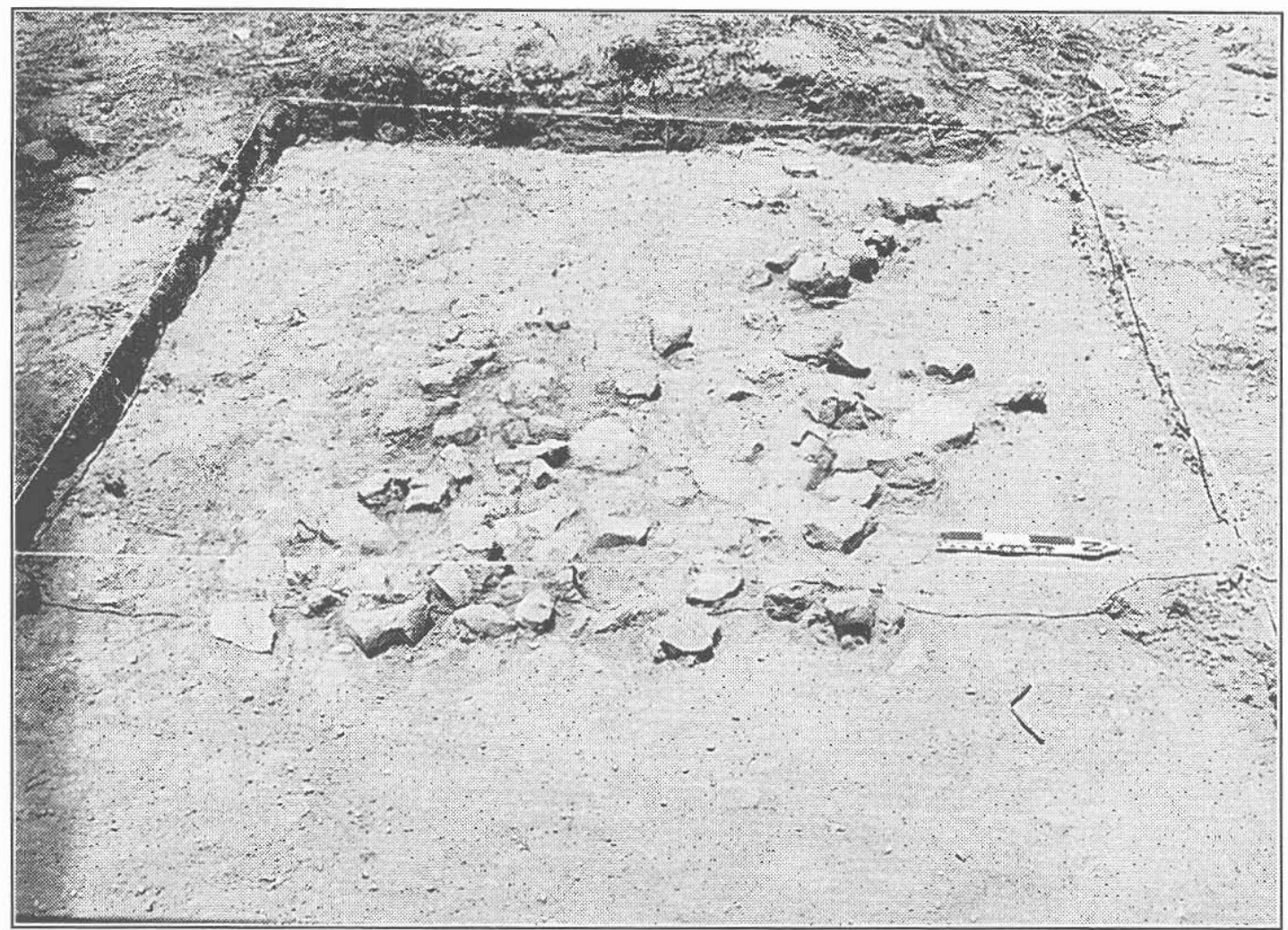

FIGURE 15. Feature 9, looking west.

\section{Feature 9}

Feature 9 was a disturbed hearth remnant located on the south side of the road in the east excavation area (Fig. 2B). The diameter of the hearth's main circular area was roughly $1.1 \mathrm{~m}$ east-west by $1.5 \mathrm{~m}$ north-south, with burned mcks scattered from this circular area an additional $70-80 \mathrm{~cm}$ to the west (Figs. 4B, 15). The feature was first exposed extending into the west wall of Unit S1/E243, Level 1; so Unit S1/E 241, Level 1, was excavated to completely expose the feature.

The feature was one layer of rocks thick, with numerous gaps between the rocks. The rocks did not form a tight circle, but were rather loosely organized and somewhat scattered about. They were highly fragmented and crushed. Theburned rocks rested atop bedrock gravels, while the tops of the highest rocks were exposed on the surface prior to excavation. Apparently this area had suffered from considerable erosion and disturhance prior to investigation.

The hearth was situated just a meter south of the edge of the county road, at the same elevation, and obviously had experienced repeated compression and disturbance from vehicular traffic. The burned rocks themselves were extremely crumbly and powdery - apparently the result of having been crushed from the weight of the traffic - while the surrounding soil matrix was severely compacted. The result was that it was very difficult to remove the soil matrix from around the rocks without also causing the complete disintegration of the rocks themselves.

The hearth did not appear to be trul yintact but appeared to have been disturbed, with the rocks reoriented, subsequent to its use. None of the hearthstones was cracked in place and all were highly fractured. The hearth did not display a basin shape, but appeared to have rested on a flat surface. Apparently the feature was originally a flat, circular hearth one layer of rocks thick. Subsequent disturbance had disrupted the feature's structural integrity and scattered the hearthstones from their original position.

No diagnostic artifacts were recovered from Feature 9 , but there was an abundance of flint debris among and around the scattered hearthstones and general vicinity of Feature 9. There also was an abundance of burned rocks on the ground surface in the vicinity of Feature 9.

Feature 9 was situated within just a few meters of Features 7 and 10 to the west, and Feature 11 to the northeast. Feature 8 was less than $2 \mathrm{~m}$ due north of Feature 9 This proximity suggests that these features 
were related in some organizational way. Although the entire area was near the southeast margin of the site, it apparently saw a great deal of aboriginal activity, based on the quantity of features and surface debris present.

\section{Feature 10}

Feature 10 was discovered on the last day of investigations at the site, so it was not fully exposed or documented. It was located in the east excavation area on the south side of the road, just $4 \mathrm{~m}$ or so east of Feature 7 (Fig. 2B). The feature was found partially in Unit S2/ E227, Level 2, and extended northward into an unexcavated portion of the site.

The feature, an apparent hearth, was a small, subcircular accumulation of burned limestone rocks. Exact size and shape of the hearth remain unknown, since the northern portion of the feature was not excavated; however, the arc and curvature of the exposed portion seemed to indicate that at least half the feature had been exposed (Fig. 16).

The hearth, as exposed, consisted of a half circle of tightly clustered burned rocks measuring approximately $40 \mathrm{~cm}$ east-west by $30 \mathrm{~cm}$ north-south (Fig. 16). The hearth was one layer of rocks thick and rested on a flat surface. The rocks were small to medium-size cobbles and were highly burned.

The soil among and below the rocks was organically stained and burned to a dark grayish brown color, in contrast with the lighter reddish tan of the surrounding soil matrix. A pocket of wood charcoal was present at the south edge of the hearth (Fig. 16B) and extended beneath the rocks.

A biface fragment and a mussel shell were present just south of the hearth (Fig. 16B), and some miscellaneous burned rocks in the vicinity at the same level were presumed to have been scattered from this hearth. Flint debris was scattered about the hearth as well Feature 10, like others in the area, appeared to have been part of a complex of features representing activities conducted in the southeast portion of the site. This hearth was smaller than the others excavated, and might have served a different function. 

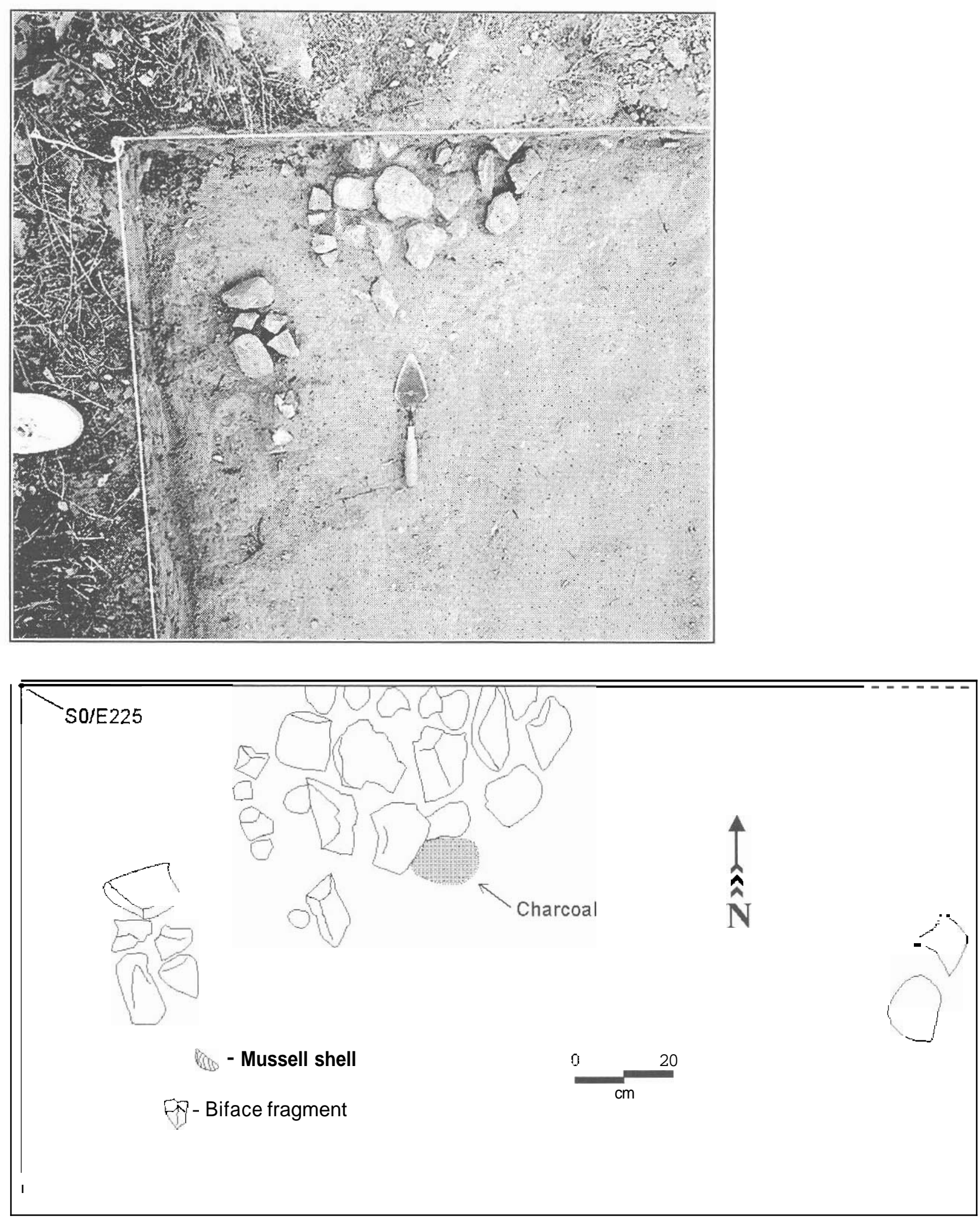

FIGURE 16. Feature 10. A (top), photo of exposed southern portion of feature, looking north; B (bottom), plan drawing of exposed portion of feature. 


\section{Artifacts}

An in-depth analysis of the lithic debitage from Site 41KM3 was not attempted because it became obvious even during testing that the recovered materials were not representative of the site, and therefore would not furnish a true picture of the site's activities or even a statement about the occupants' lithic technology. This conclusion arose as a result of several factors.

First and foremost was the fact that the area sampled had been disturbed by previous road-building activities which resulted in extensive damage to the flint specimens. Most of the flint within the right-of-way had been broken or altered by heavy machinery. Road construction and years of exposure to animal and vehicular traffic had effectively reduced the lithic sample to small broken and crushed pieces with nonaboriginally altered edges and surfaces. These alterations did not reflect aboriginal use and in fact largely obscured the detection of such use, if it had been present.

In addition to altering the characteristics of individual specimens, this same road-construction activity no doubt displaced a large majority of the material, resulting in the recovery of specimens out of context. Materials originally from within the roadway had been pushed atop deposits alongside the roadway, possibly resulting in a reverse chronology. Therefore, even if a discrete tool kit or knapping technology could have been identified, associating it with other intrasite or intersite artifacts, features, or activities would have been impossible.

Compounding this provenience problem was the erosion, denuding, and deflation factor that resulted in materials from various time periods ultimately coming to rest upon the same surface, or at least being recovered from the same context. Materials that seemed to have originated upslope on the terrace top had washed down into, and were recovered from within, the right-of-way. The result was that very little material could be relied upon as being in situ. Even though multiple occupations no doubt occurred at the site, except for diagnostic dartpoint types, the residue from individual occupations or even components could not be isolated.

A final consideration was the fact that the area sampled was extremely peripheral to the main body of the site. Even if the area had been excavated more extensively, if the materials had not been damaged, and if the provenience of the recovered materials had been more reliable, it is doubtful that the materials recovered would have represented the main activities conducted at the site or even a complete cross section of a single activity. That is, it might be the case that peripheral areas around a site represent peripheral activities or, alternately, that a peripheral area represents only a single stage of some activity whose major emphasis was conducted elsewhere. In either case, the materials recovered would not be representative of the site as a whole.

Therefore, most of the materials recovered from the investigated areas of Site 41KM3 were not considered reliable indicators of the site's function or level of lithic technology. Only those specimens that were obviously tools or, that is, those specimens that had obvious aboriginal alterations, were studied as artifacts; all else was considered debitage. The debitage was not analyzed further; that is, it was not sorted into types of flakes, types of flint, manner of production, or any other standard analysis categories. The debitage was simply counted by unit and level to give an indication of the volume of flint debris recovered from the areas investigated. The results are presented in Table 1.

In the West Excavation area, only one excavation unit produced flint debitage beyond Level 1, and that was the unit farthest downhill and nearest the creek (Unit S6/W 4). This unit also was the only one in the West Excavation area where bedrock was not encountered in Level 1. Downhill slopewash and overbank flooding in this area of the site might possibly account for the soil build up and accumulation of flakes in this unit. Even so, the recovery was very small and insignificant.

In the East Excavation area, 9 of 12 excavation units produced no flakes beyond Level 2, and only two units produced flake debitage beyond Level 3. This distribution appears to indicate an area of concentrated aboriginal activity 2-3 $m$ west and southwest of the large basinshaped hearth (Feature 7). No similar pattern was discovered near other hearth features. However, the other hearth localities seemed to have suffered from more severe denuding and erosion, as well as road-grading activities, so perhaps the statistics are skewed in favor of the more intact deposits.

After the debitage was sorted and quantified, the remaining artifacts were divided into the following categories: Utilized Flakes, Modified Flakes, Nondiagnostic Bifaces, Projectile Points, Miscellaneous Artifacts, and Cores. 
TABLE 1: Provenience of lithic debitage.

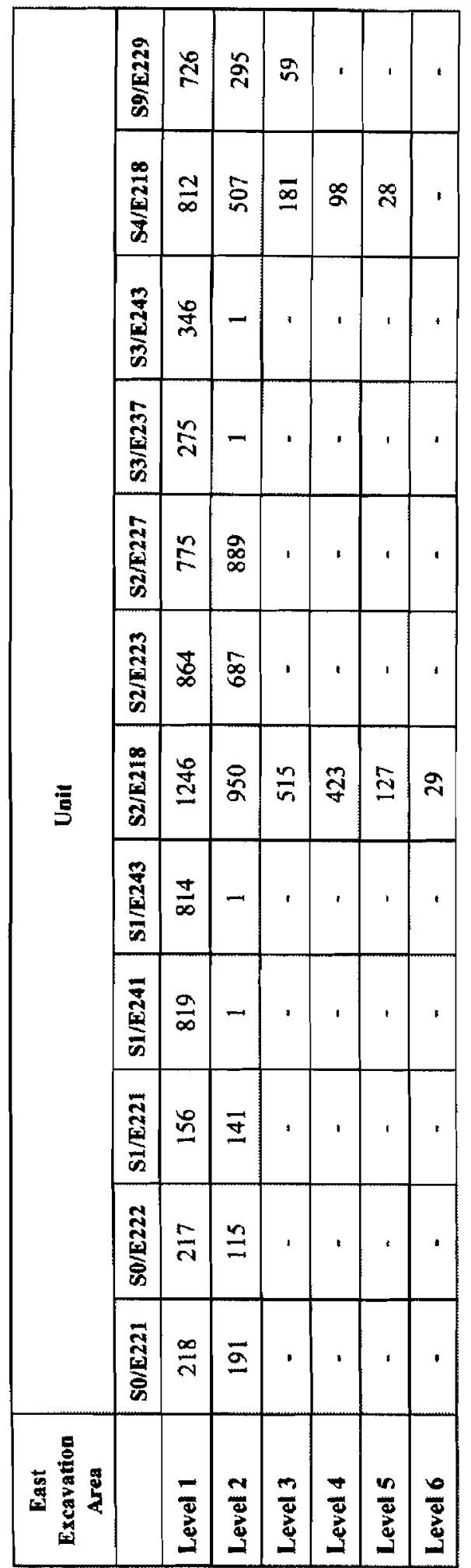

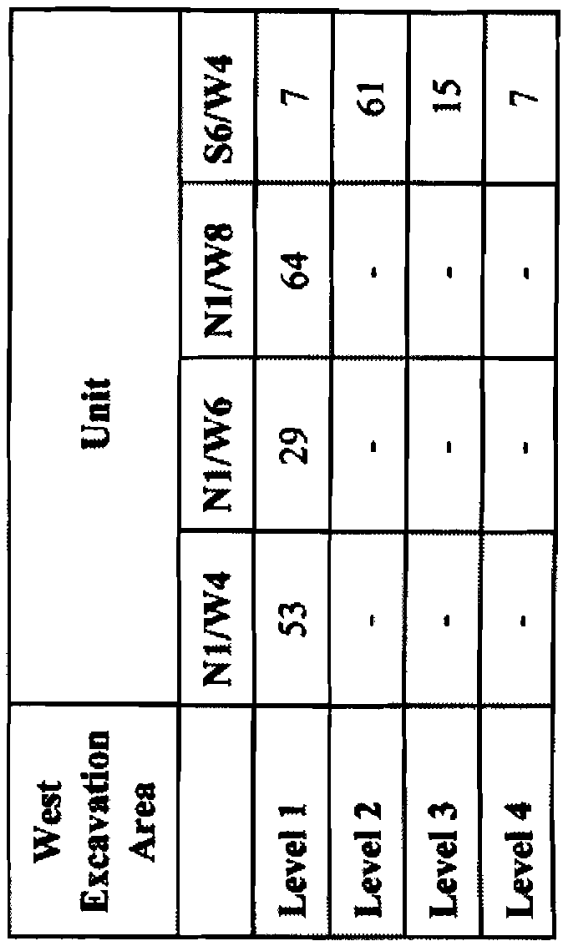




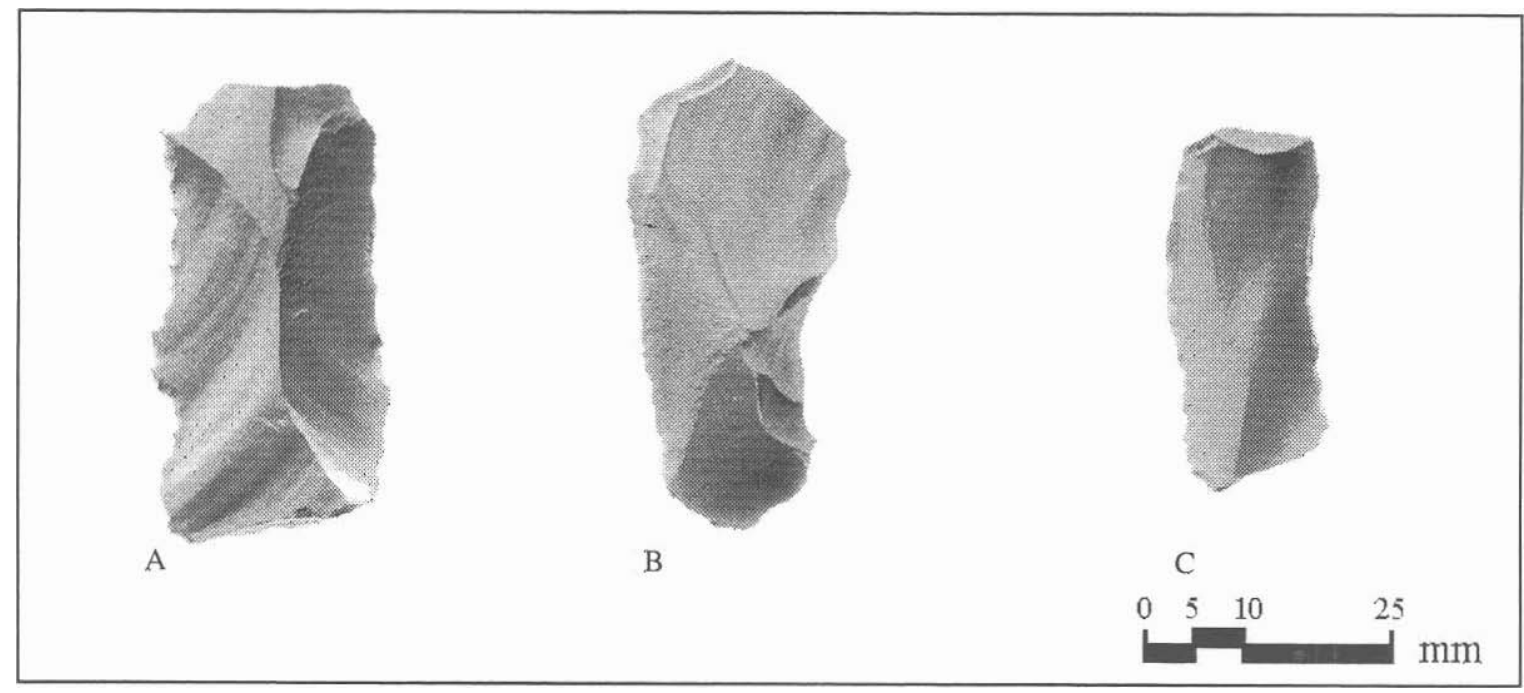

FIGURE 17. Small. thin utilized flakes

\section{Utilized Flakes}

A utilized flake is herein defined as any flake that exhibits unintentional and inadvertent alteration to one or more of its edges as a result of aboriginal use, as opposed to the deliberate and intentional aboriginal modification of an edge in order to create a preconceived edge angle or shape. Because of the previously mentioned recent damage to the lithic collection, it was difficult to discern aboriginal use wear on a flake edge from that caused by modem trauma to the flake. Therefore, only the obvious cases of aboriginal alteration were considered as tools; all else was considered to be debitage.

A total of 35 flakes exhibited use wear on one or more edges. These flakes were divided into two categories: thin. billet flakes with keen edges appropriate for cutting or sawing activities; and thick chunky pieces of flint with less acute edges more suitable for scraping activities.

There are 24 examples of the first type of utilized flake (Fig. 17). Of these, the degree of use wear ranges from slight nibbling to extensive gouging; the size of the flakes averages $4 \mathrm{~cm}$ in length and $0.5 \mathrm{~cm}$ in thickness. Generally, the utilized edges are on the long dimensions of the flakes.

The second category of utilized flakes contains 11 specimens (Fig. 18). These blocky pieces of flint are hardhammer flakes, larger and cruder than specimens in the first category. In general, the use wear in this category is more extreme and more irregular; it frequently appears on two opposing edges. The size of the flakes averages $6 \mathrm{~cm}$ in length and $1.5 \mathrm{~cm}$ in thickness. The edge angles and extent of wear suggest that these tools were used in scraping activities.

Provenience of all utilized flakes is given in Table 2. Like the debitage in general, utilized flakes seem to have been concentrated in the units $\mathbf{2 - 3}$ m west and southwest of Feature 7. There, utilized flakes occurred in all five levels and in greater abundance than elsewhere. Again, this distribution might simply be a function of the amount of disturbance throughout the site.

\section{Modified Flakes}

A modified flake is herein considered to be any flake that exhibits deliberate and intentional alteration through the removal of small trimming flakes from one or more of its edges, versus the inadvertent and unintentional alteration of an edge produced through use. The trimming, which in every case in this assemblage is unifacial, has been done in order to accomplish a desired shape or edge angle.

There are 24 modified flakes in the collection from the Red Creek Site. These flakes can be divided into two general categories based on degree of edge angle: those flakes with steep bits or angles greater than $45^{\circ}$ for which a scraping activity is presumed, and those flakes whose edge angles are $45^{\circ}$ or less for which a cutting or sawing activity is presumed.

There are 15 scrapers in the first category (Fig. 19). These tools range from flakes with crude, edentate edges to pieces with very finely trimmed and uniform scraping edges. Several pieces have edges that appear to have been utilized to their maximum potential; that is, their edges have been blunted beyond further use and their bit angles 


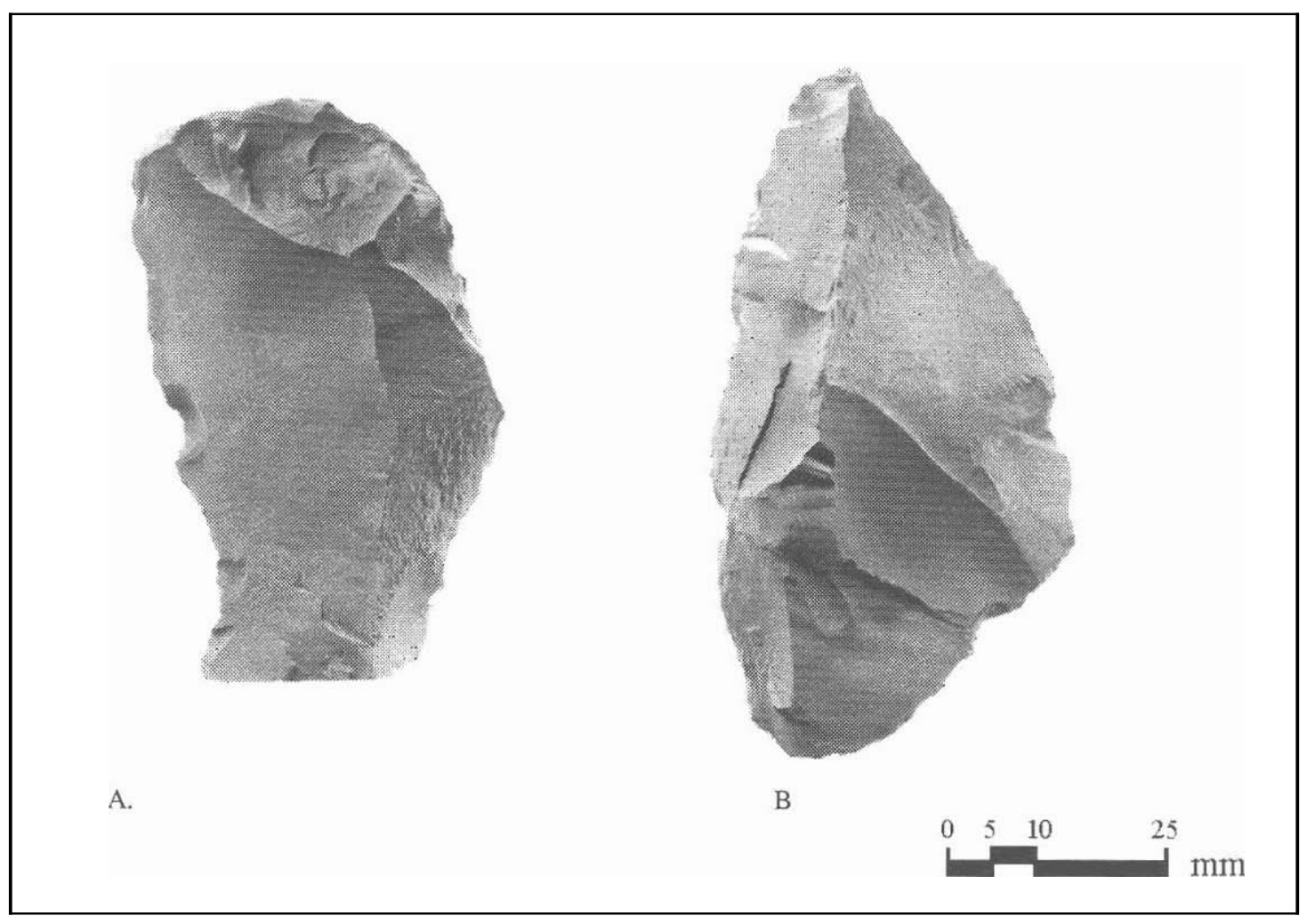

FI GURE 18. Large, chunky utilized flakes.

are quite obtuse. Two specimens (Fig. 19A,B) have blunt bit angles approaching $90^{\circ}$. One of these specimens (Fig. 19B) has the remnants of a beaked edge adjacent to its scraping edge.

Cortex is present on 11 of the 15 flakes in this category, suggesting that primary and secondary flakes were deliberately chosen or produced for the purpose of modification into scrapers. These tools fit nicely into the palm of the hand, with the cortex-backed portions resting snugly against the palm or against the inside of the thumb and forefinger.

There are 9 modified flakes in the second category (Fig. 20). These flakes have neatly executed, fine trimming flakes on one side each. The resultant blades seem ideal for cutting or sawing. Several show evidence of use in the form of blunted or worn sections along the worked edges. Most of the specimens in this category are fragmentary and not much can be said about original shape and size.

Provenience of all modified flakes is given in Table $\mathbf{3}$. Like utilized flakes and flake debitage, the modified flakes seem to have been concentrated in the area 2-3 m west and southwest of Feature 7, and in Feature 7 itself. Again, this distribution should be viewed with caution because of the great amount of disturbance and displacement of materials in this portion of the site.

\section{Nondiagnostic BifaCES}

There are 81 tools from the Red Creek Site that have been classified as nondiagnostic bifaces. Nondiagnostic bifaces are defined as bifaces that are not projectile points. These bifaces were roughly sorted into three categories, based on degree of flaking around the edges and across the faces.

The first category is made up of crude, chunky pieces whose edges have been roughly formed by hard-hammer percussion (Fig. 21). There are 23 specimens in this category. They are large, averaging $6 \mathrm{~cm}$ in length, and thick, averaging $2 \mathrm{~cm}$ in thickness. Their sinuous edges show no signs of further retouch beyond their initial crude shaping by hard hammer. Many of these tools are themselves large, hard-hammerflakes that have been removed from cores and then roughly bifaced. On the other hand, an equal number appear to be bifaced cores that have been reduced down to their present size. Almost all (20 of 23) retain some remnants of cortex on their surfaces. Most have been fractured and show signs of 
TABLE 2. Provenience of utilized flakes.

\begin{tabular}{|c|c|c|}
\hline 音 & 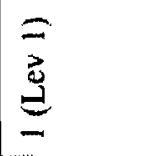 & \\
\hline 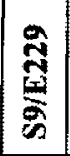 & 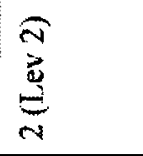 & $\underline{\bar{a}}$ \\
\hline 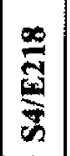 & 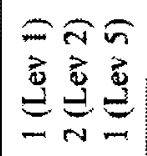 & 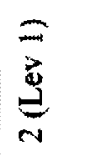 \\
\hline 胥 & 言 & \\
\hline $\mid \frac{\hat{\pi}}{\hat{m}}$ & $\stackrel{\bar{a}}{a}$ & \\
\hline 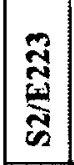 & 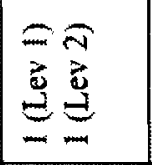 & 氞 \\
\hline 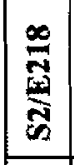 & 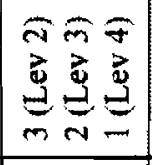 & \\
\hline 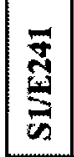 & 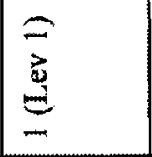 & 苞 \\
\hline ฐี & 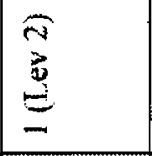 & \\
\hline$\sum_{z}^{\infty}$ & $\underline{\underline{e}}$ & \\
\hline t & $\mathrm{m}$ & 0 \\
\hline 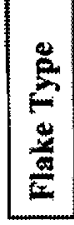 & 惫旁 & 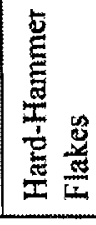 \\
\hline
\end{tabular}

TABLE 3. Provenience of modified flakes

\begin{tabular}{|c|c|c|}
\hline t & - & - \\
\hline స్్ㅊ & 氛余 & \\
\hline $\begin{array}{l}\stackrel{\infty}{\tilde{y}} \\
\text { 勇 }\end{array}$ & 家 & 氛商 \\
\hline 彎 & & ב气 \\
\hline జู. & 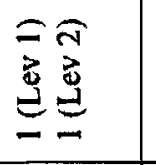 & \\
\hline :ึ & 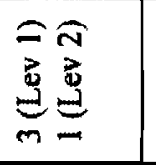 & 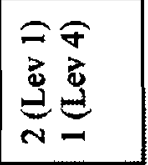 \\
\hline$\frac{7}{3}$ & $\widehat{\underline{\overrightarrow{3}}}$ & \\
\hline 宽 & 胥 & 产 \\
\hline 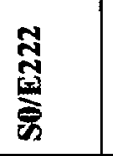 & 矛 & \\
\hline 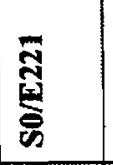 & $\stackrel{0}{\overrightarrow{3}}$ & \\
\hline$\overline{\bar{y}}$ & - & \\
\hline 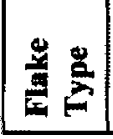 & 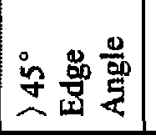 & 的品哭 \\
\hline
\end{tabular}




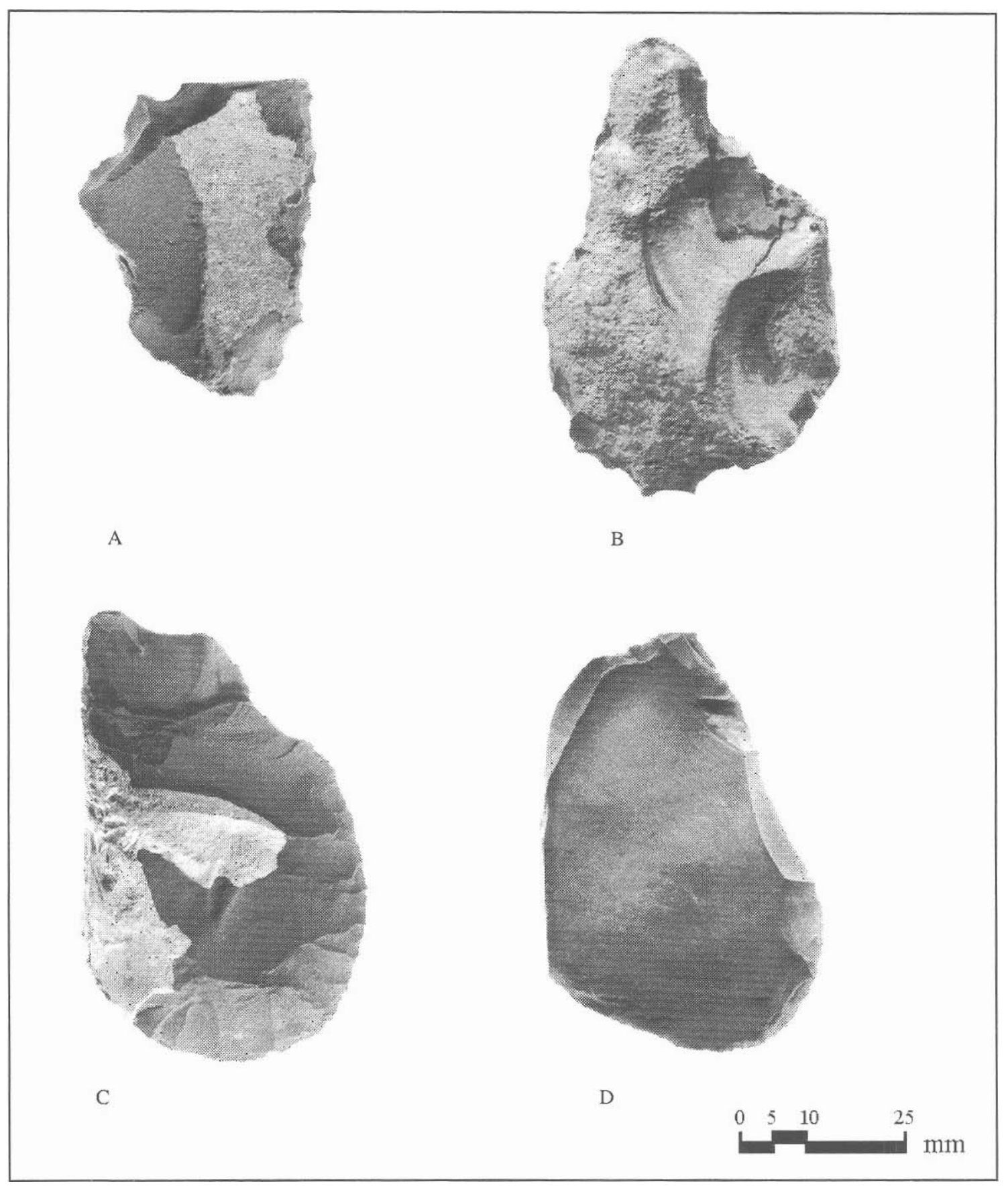

FIGURE 19. Modified flakes. 


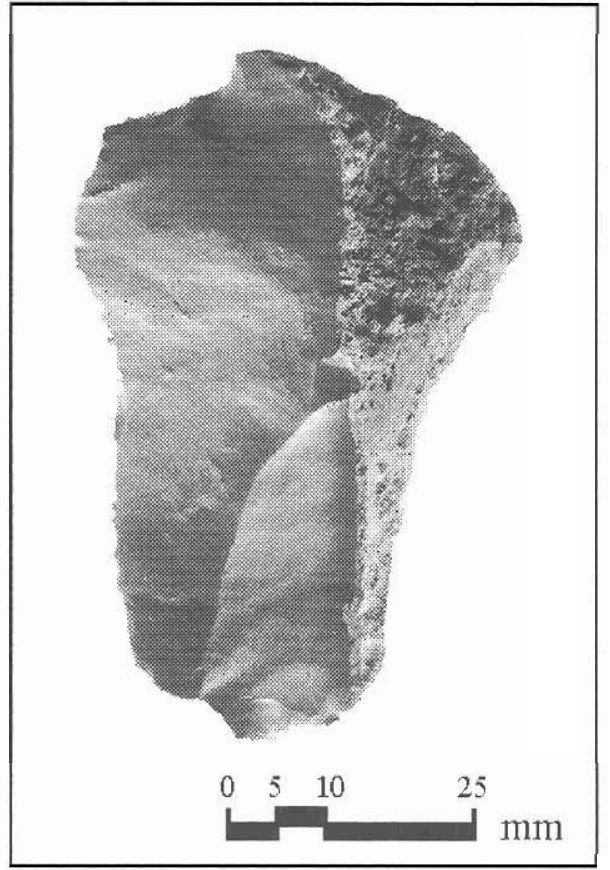

FIGURE 20. Modified flakes.

recent damage.

The second biface category (Fig. 22) contains specimens that have been thinned to a greater degree than those in the first category, by means of further removal of flakes from the edges and across the faces. There are 27 specimens in this category. The edge modification of specimens in this category was given more attention by the aboriginal knappers than in the previous category, resulting in uniform, straighter edges and more acute edge angles. Most specimens are flaked across both faces, and only two specimens retain cortex. These artifacts are commonly called "blanks" in the literature. Many show snap fractures or manufacturing breaks, indicating a reason why these pieces were not further worked into finished tools.

The final biface category (Fig. 23) contains specimens whose edges have been keenly worked through a series of fine trimming flakes and that have been thinned by flaking across the entire surfaces of both faces. There are 31 specimens in this category. All are broken or fractured so that original shape and size cannot be determined; some might be fragments of projectile points. Some appear to have been finalized tools that snapped or broke during use; their edges appear dull and worn. Others appear to have broken during the final stages of manufacturing; their edges are sharp and keen. There are several (Fig. 23) that demonstrate expert flaking ability on the part of the craftsperson. Thickness of these specimens averages 4 $\mathrm{mm}$; the flake scars along the edges are uniformly placed, creating parallel scars of the same size and orientation.

Provenience of all nondiagnostic bifaces is given in Table 4. Distribution of bifaces somewhat parallels that of utilized and modified flakes, although in general bifaces appear to have been more widespread across the site. Bifaces also are more numerous in the collection than utilized and modified flakes. This distribution could easily reflect an analytical failure to recognize utilized and modified flakes from among the debitage, a condition occasioned by the large-scale disturbance and damage to site materials prior to examination. That is, a biface can much more easily he recognized and isolated from debitage than can utilized and modified flakes. At any rate, the biface pattern is more heavily distributed throughout the site, even though the areas of concentration are the same. It appears that bifaces, like utilized and modified flakes, were concentrated to the west and southwest of Feature 7.

\section{Projectile Points}

\section{Angostura-Like (1 SPecimen, Fig. 24A)}

This specimen is the basal portion of an Angosturalike projectile point. The fragment is narrow and thin, and contracts toward a base that is slightly concave. The edges of the sides and base have been ground. The specimen is lenticular in cross section.

The specimenwas broken through a snap fracture that occurred somewhere proximal to its original maximum width. The remaining portion is thus expanding toward the distal end. Measurements are: length, $0.6+\mathrm{cm}$; thickness, $0.4 \mathrm{~cm}$; depth of basal concavity, less than 0.1 $\mathrm{cm}$. The specimen was recovered from S2/E218, Level 2.

\section{Early-Stemmed (1 Specimen, Fig. 24B)}

This specimen is so highly fragmented that an accurate description is hardly possible. Very little remains, except a portion of the midblade and the lower stem and base. The stem appears to have been expanding into two downward-pointing prongs with a $\mathrm{U}$-shaped groove in the base, reminiscent of the Gower or Uvalde type. Pertinent measurements are: stem length, $1.3+\mathrm{cm}$; stem width, $2 \mathrm{~cm}$; thickness, $0.7 \mathrm{~cm}$; depth of basal concavity, $0.5 \mathrm{~cm}$. This specimen was recovered from the surface. 


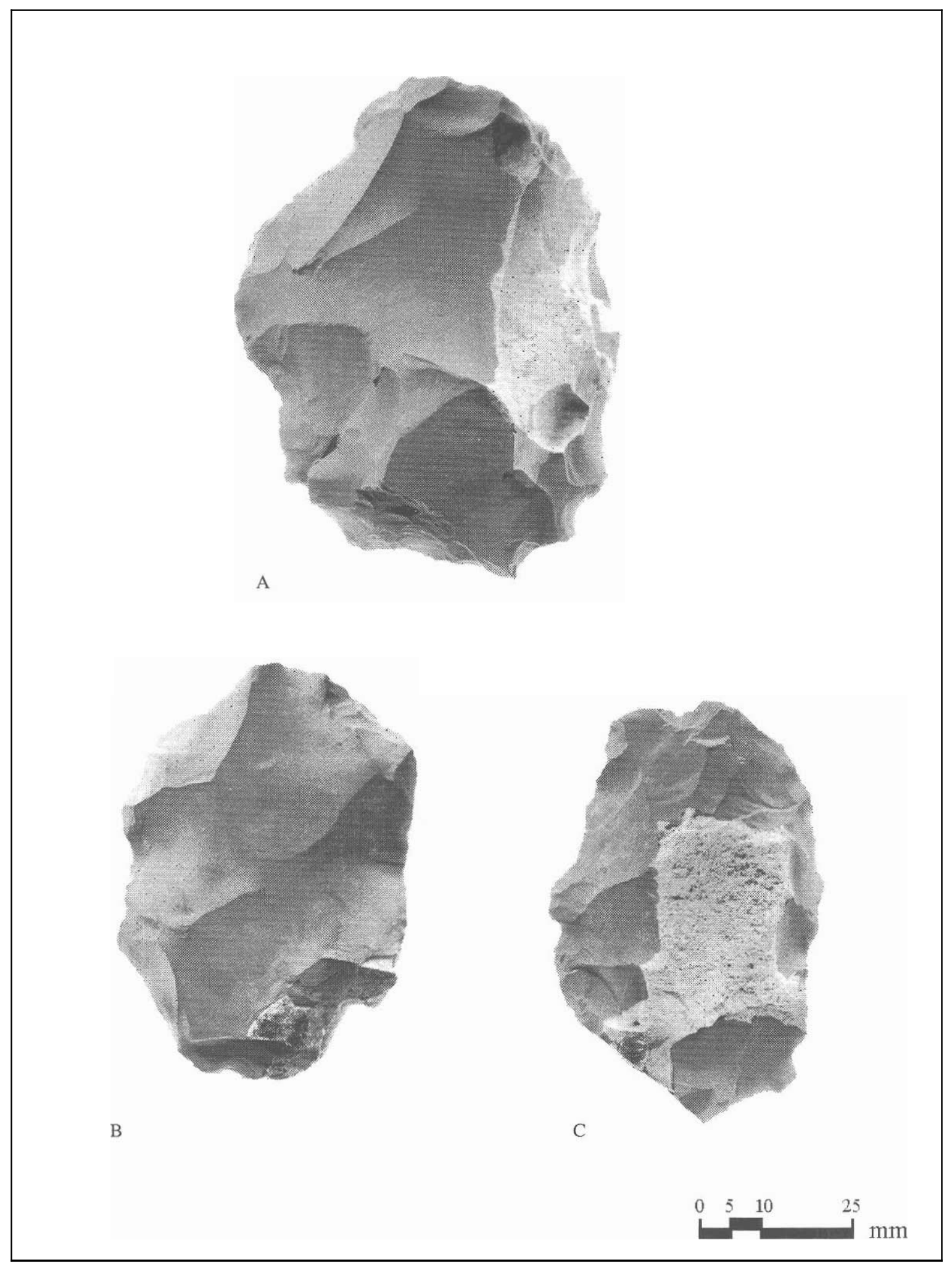

FIGURE 21. Large bifaces. 


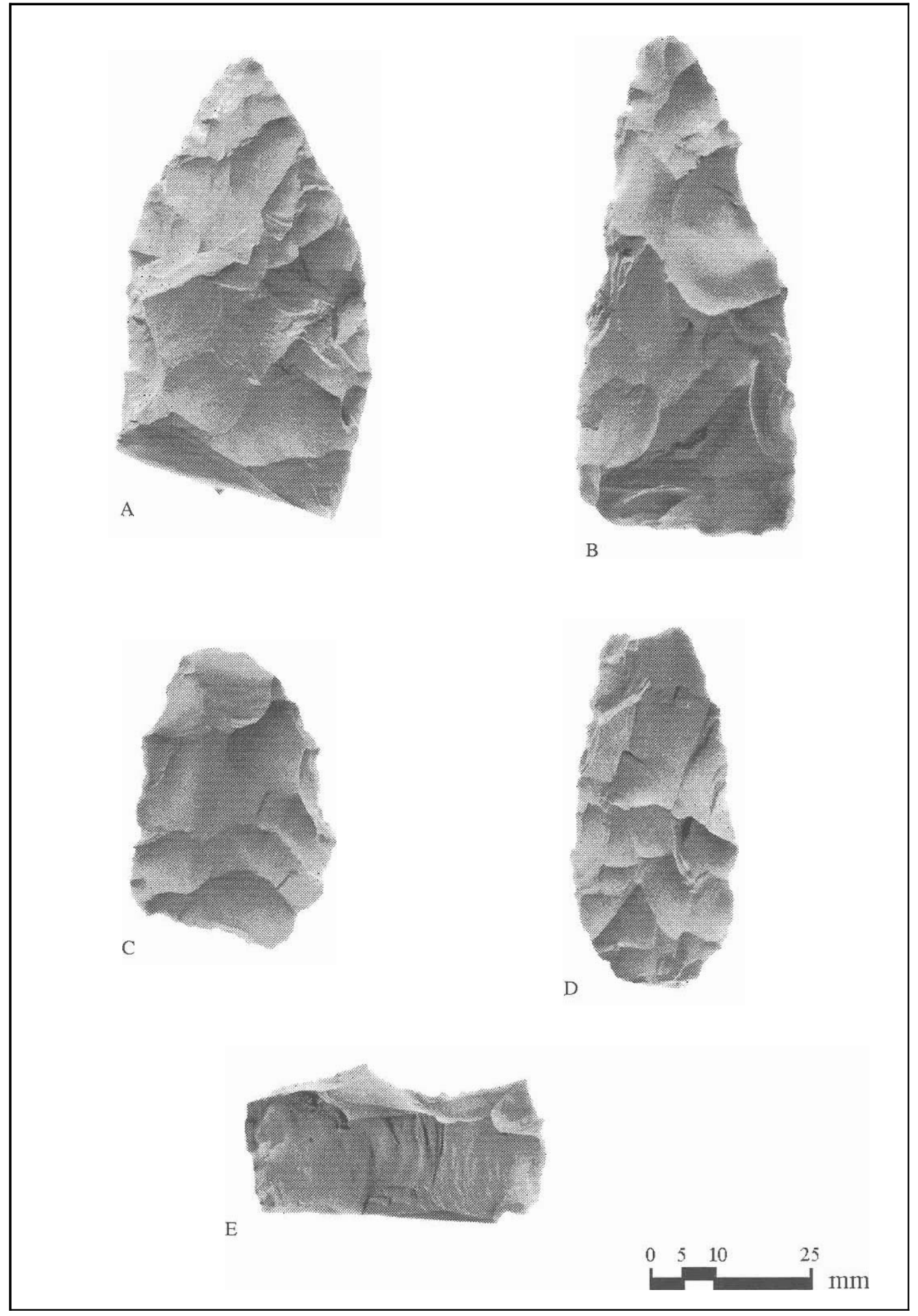

FIGURE 22. Biface "blanks." 


\section{Andice (1 specimen, Fig. 24C)}

This specimen appears to be an extensively reworked Andice projectile point that had lost its barbs and most of its blade prior to reshaping. It appears to be an attempt to salvage the stem and lower medial section of a tool that shows severe damage to the midsection just above the shoulder area. In this area, major fractures originating from both edges are present on one face; these fractures appear to have removed the distal end of the blade and both barbs. What remained after the initial damage was an intact stem, a small portion of the lower midsection, and the shoulders where the barbs had snapped off.

Reasons for labeling this specimen an Andice are the treatment of the edges of the stem and the rounded area at the juncture of the stem with the original barbs. That is, because typically the notch separating the stem from the barb on an Andice point is not very wide, the circular area at the top of the notch is tight and narrow. Likewise, because the length of the barbs is typically equal to the length of the stem, access to the stem for edge trimming would be prohibitive, requiring some sort of alternating flaking from opposite faces of the tool.

This specimen shows both these characteristics. What remains of the arch at the juncture of stem and barb is quite acute. It has been worked from the base. The sides of the stem have been alternately flaked in a series of small, patterned flake removals originating from opposite sides of the tool. These flake removals created a sinuous edge that was not ground.

The stem itself is straight-sided with a concave base. Measurements are: length, $4.8+\mathrm{cm}$; width, $3.3 \mathrm{~cm}$; thickness, $0.7 \mathrm{~cm}$; stem length, $1.9 \mathrm{~cm}$; stem width, 1.9 $\mathrm{cm}$; depth of basal concavity, $0.2 \mathrm{~cm}$. The specimen was recovered from the surface.

\section{Bell (1 specimen, Fig. 24D)}

This specimen is a broken barb of what was no doubt a Bell point. The barb is parallel-sided and straightbottomed. It has been worked more extensively on one face than on the other, and is wedge-shaped, tapering toward its outer edge. It appears to have snapped off the projectile point just at the juncture of the barb with the main body of the tool. Measurements are: length of barb, $2.1 \mathrm{~cm}$; width of barb, $1.3 \mathrm{~cm}$; thickness of barb, $0.4 \mathrm{~cm}$. The specimen was recovered from S0/E221, Level 2.
TABLE 4. Provenience of bifaces.

\begin{tabular}{|c|c|c|c|}
\hline 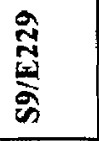 & 商总 & $\frac{0}{3}$ & $\underline{\underline{3}}$ \\
\hline$\frac{\infty}{\mathbb{3}}$ & $\underbrace{0}_{\overrightarrow{3}}$ & 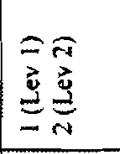 & 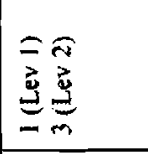 \\
\hline $\begin{array}{l}\stackrel{3}{4} \\
0 \\
0 \\
0\end{array}$ & 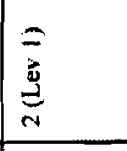 & & \\
\hline$\frac{\sqrt[n]{3}}{3}$ & & $\stackrel{3}{3}$ & \\
\hline 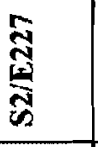 & 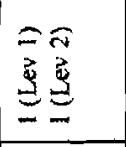 & 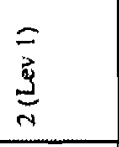 & 氛意 \\
\hline 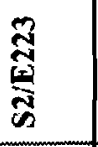 & & $\underline{\overline{3}}$ & 产 \\
\hline 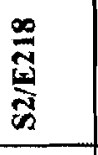 & 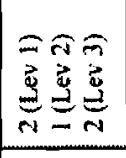 & 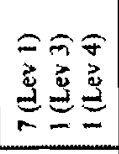 & 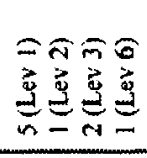 \\
\hline 赵 & & 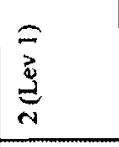 & \\
\hline$\underset{N}{\approx}$ & $\underline{3}$ & 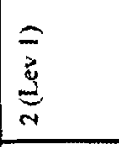 & 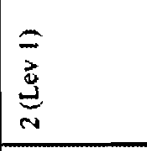 \\
\hline สี & & & $\underline{\underline{E}}$ \\
\hline 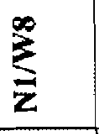 & & 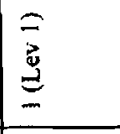 & \\
\hline 竞 & $a$ & in & $n$ \\
\hline 慝 & 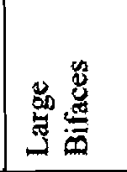 & 篦 & 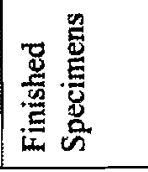 \\
\hline
\end{tabular}




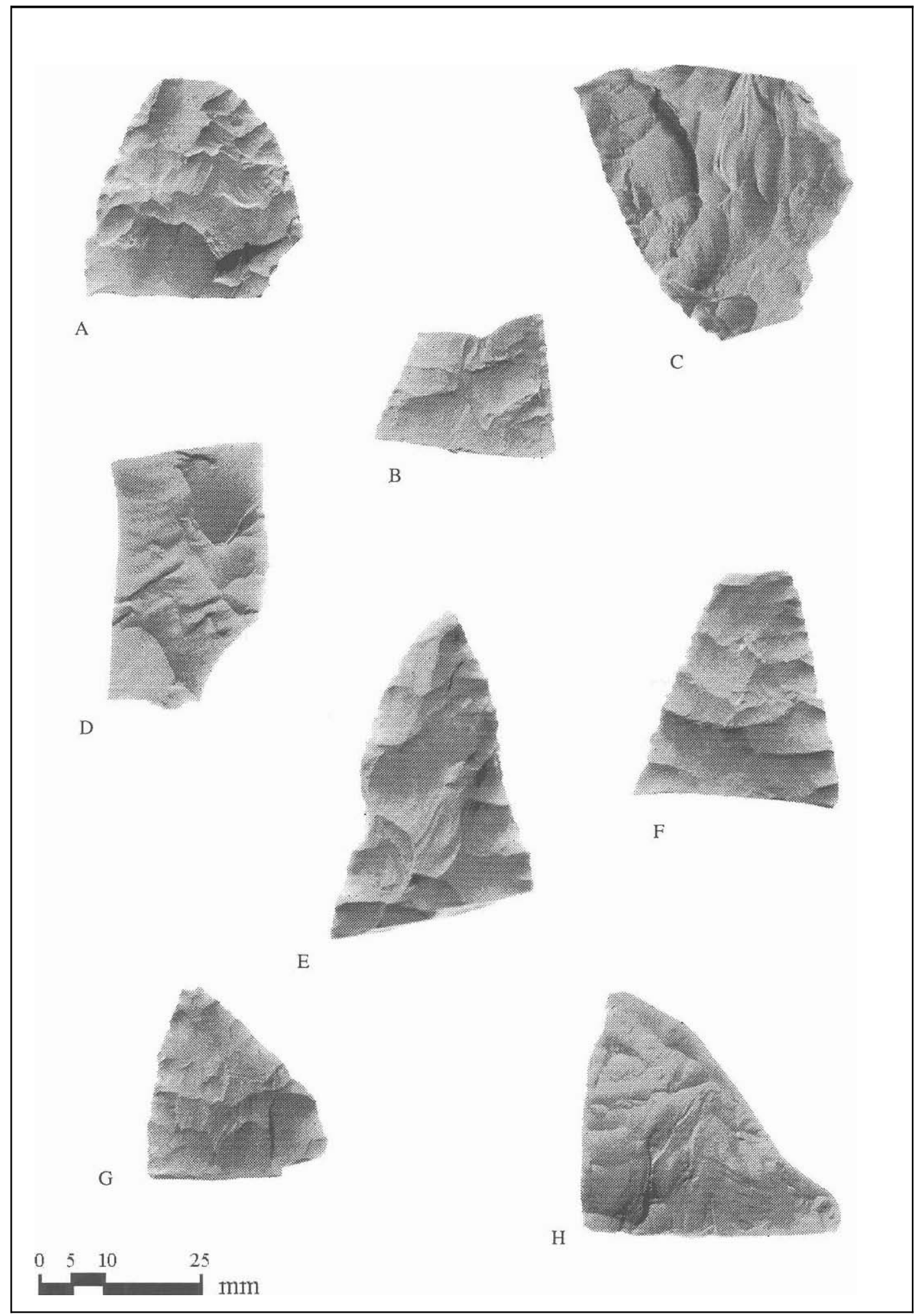

FIGURE 23. Finished bifaces. 


\section{Side-Notched (2 SPECIMENS, Fig. 24E,F)}

These specimens are characterized by slightly expanding stems with shallow side notches. Shoulders are weak and rounded, and bases are straight. Blades are triangular with straight edges. These specimens bear a vague resemblance to La Jita type, but they are smaller and do not have rounded stems.

The first specimen (Fig. 24E) has been completely reworked on the edge of one face, from the base to the distal tip. On the opposite edge, the stem and cornernotch area have been damaged and slightly reworked. This specimen is somewhat crude and bulbous. Measurements are: length, $3.9 \mathrm{~cm}$; width, $2.4 \mathrm{~cm}$; thickness, $0.6 \mathrm{~cm}$; length of stem, $1.2 \mathrm{~cm}$; width of stem, $2.1 \mathrm{~cm}$. This specimen was recovered from the surface.

The second specimen (Fig. 24F) is more finely made. The blade is triangular with straight edges. The remaining shoulder (one has been fractured away) is very weak and rounded. The stem and base are straight. The side notching is very slight and subtle. Measurements are: length, $4.6 \mathrm{~cm}$; width, $2.7 \mathrm{~cm}$; thickness, $0.6 \mathrm{~cm}$; length of stem, $0.6 \mathrm{~cm}$. This specimen was recovered from Feature 4.

\section{Bulverde-Like (1 SPecimen, Fig. 24G)}

This specimen bears a resemblance to the Bulverde type. Half the lower stem, part of one shoulder, and almost all of the base are missing so that stem, shoulder, and basal treatment is somewhat obscured. However, what remains indicates a slightly contracting stem and shoulders that are weak and rounded. There are no barbs. The blade is triangular and has been resharpened, as evidenced by flake scars that postdate the development of patina across the surfaces of the tool. Measurements are: length, $5 \mathrm{~cm}$; width, $2.8 \mathrm{~cm}$; thickness, $0.7 \mathrm{~cm}$; length of stem, $1.4 \mathrm{~cm}$; width of stem, $1.7+\mathrm{cm}$. This specimen was a surface find.

\section{Nolan (1 SPECIMEN, Fig. 24H)}

This projectile point is characterized by a triangular blade and slight, upturned shoulders. The parallel-sided stem is alternately beveled and the base is straight. Measurements are: length, $5 \mathrm{~cm}$; width, $3.4 \mathrm{~cm}$; thickness, $0.8 \mathrm{~cm}$; stem length, $1.3 \mathrm{~cm}$; stem width, $1.9 \mathrm{~cm}$. The specimen is highly patinated and was recovered from the surface of Backhoe Trench 3.

\section{Travis-Like (1 SPecimen, Fig. 24I)}

This specimen appears to be a reworked knife whose base might have broken during use. It appears there was an attempt to reshape this broken base into a dart-point stem. The flaking that forms the stem is more recent than that along the blade edges and intrudes the older flake scars in the area where the stem joins the blade. The blade edges are convex and have been sharpened and trimmed to form a keen cutting edge. The stem sides are parallel to slightly expanding, and the base is not worked. The closest similarity to an established type is Travis, which might be what the aboriginal knapper was trying to emulate. Measurements are: length, $8.7+\mathrm{cm}$; width, 2.8 $\mathrm{cm}$; thickness, $1 \mathrm{~cm}$; stem length, $1.1+\mathrm{cm}$; stem width, $1.5 \mathrm{~cm}$. Provenience is S2/E218. Level 4.

\section{nOLAN/TRAVis FAMILy (1 SPECimen, Fig. 24J )}

This specimen is characterized by a straight, slightly contracting stem that has been unifacially beveled from both edges on the same face, as opposed to typical specimens of the Nolan type that have alternately beveled stems, and typical Travis points that have no distinct beveling. On this specimen the beveling is very steep and extends upward from the stem onto the bottom of the shoulders, which are weak and rounded. The beveling was accomplished through a series of fine, well-executed pressure flakes. On the opposite face, the stem has been thinned by a single well-executed flake, $1.5 \mathrm{~cm}$ in length, originating from the base. The base itself is flat and straight. Blade edges are straight. The specimen is missing the distal end, which has been broken off from impact. Measurements of the specimen are: length, 3.8+ $\mathrm{cm}$; width, $3 \mathrm{~cm}$; thickness, $0.7 \mathrm{~cm}$; length of stem, 1.9 $\mathrm{cm}$; width of stem, $2 \mathrm{~cm}$.

The lithic material is gray, slatey flint common to the Central Texas Mineral Region (Glenn T. Goode, personal communication, 1992), the southwestern margin of which encompasses the geographic area surrounding the Red Creek Site. The specimen was a surface find.

\section{Pedernales (6 specimens, Fig. 25A-F)}

These projectile points are characterized by broad, flat triangular blades, with prominent, barbed to squared shoulders. Stems are parallel-sided to slightly contracting. Bases are concave and are usually thinned by one or a few long thinning flakes originating from the base. In one case, there is a deeply U-shaped basal notch.

Of the 6 projectile points classified as Pedernales, 3 are nearly complete and 3 are proximal fragments. Of the nearly complete pieces, Specimens 1 and 2 (Fig. 25A,B) are missing only the very tips of the shoulder barbs, and Specimen 3 (Fig. 25C) is missing the distal end, which has been sheared off from impact.

The proximal pieces are very fragmentary. Specimen 4 (Fig. 25D) has a complete stem, a portion of the blade 


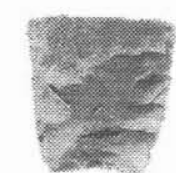

A

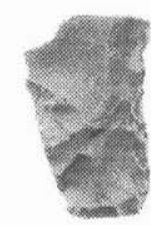

D
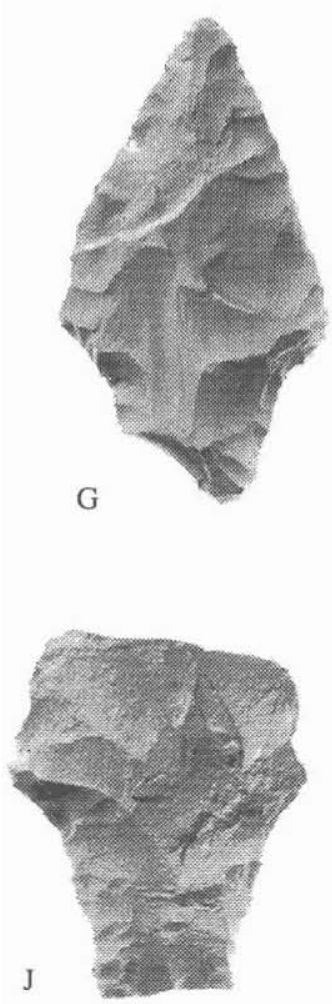

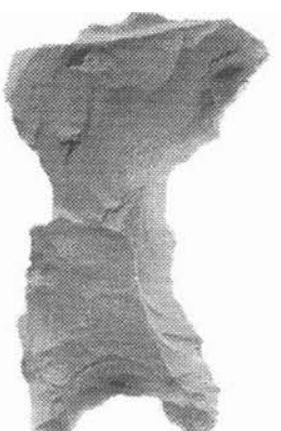

B

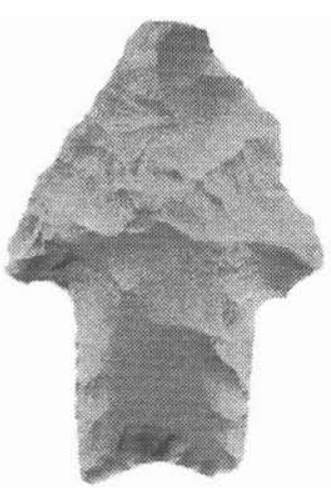

C

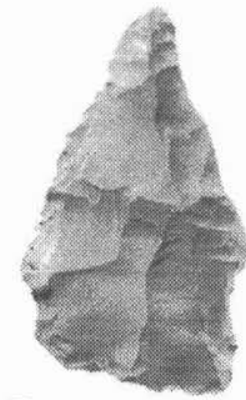

E

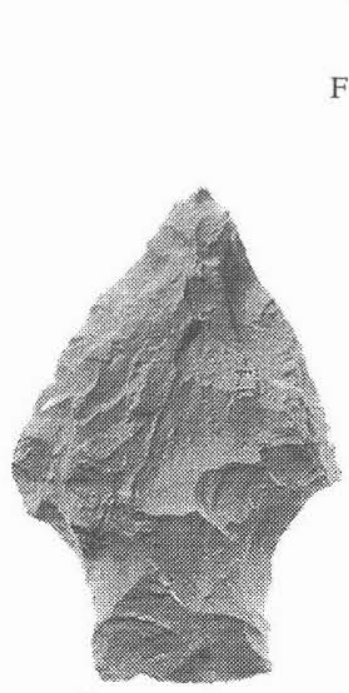

$\mathrm{H}$
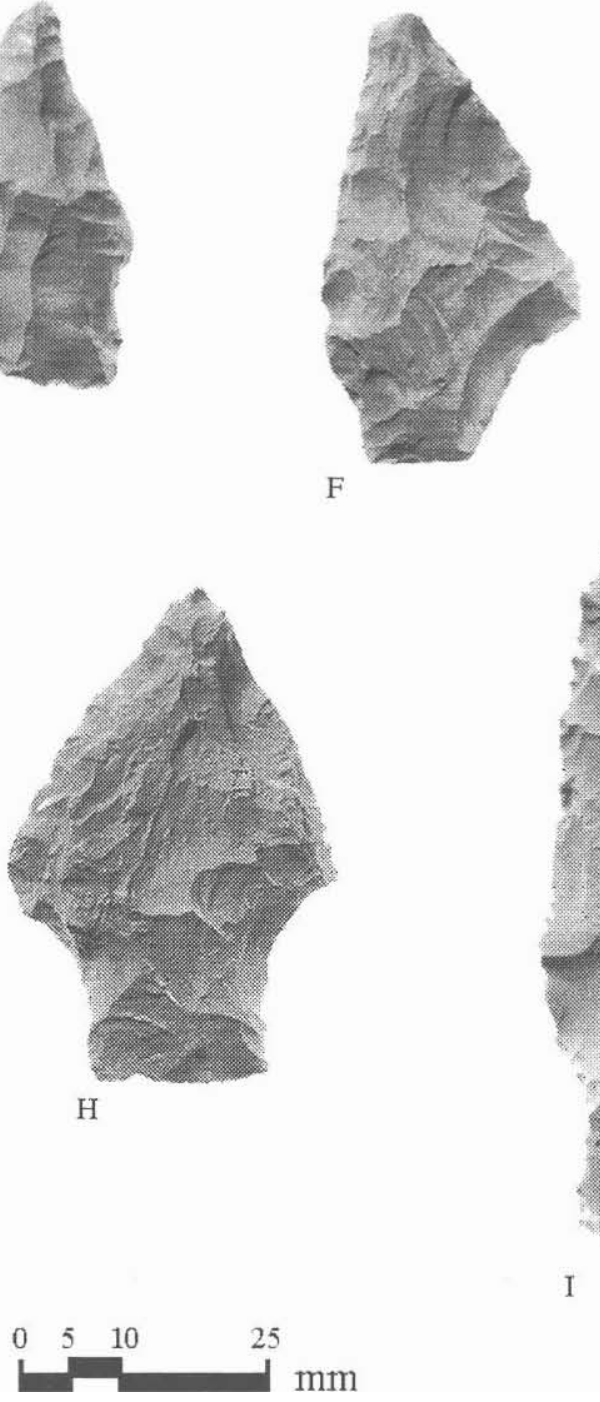

FIGURE 24 Projectile points. A, Angostura-like; B, Early-Stemmed; C, Andice; D, Bell; E,F, Side-Notched; G, Bulverdelike; H. Nolan; I, Travis-like; J, Nolan/T ravis family. 
midsection, and part of one barb. The remaining fragmented pieces (Specimens 5 and 6, Fig. 25E,F) have only portions of the stems and midsections present.

Statistical information on the Pedernales points from the Red Creek Site is given in Table 5.

\section{Contracting-STemmed (5 SPECimens, Fig. 26A-E)}

The 5 specimens in this category all have contracting stems but otherwise show a great variation in size, shape, and workmanship. Only 1 specimen (Fig. 26A) appears to be a finished tool; the 3 larger pieces (Fig. 26B-D) appear to be manufacturing failures; and the final specimen (Fig. $26 \mathrm{E}$ ) is too fragmentary to be assessed conclusively. All bear resemblances to the Langtry type. Measurements and provenience of this category are given in Table 6.

Specimen 1, the completed specimen (Fig. 26A), has a triangular blade that has been extensively reworked down one side of one face, the result perhaps of an attempt to correct an impact fracture present at the distal end which has sheared off a portion of the same side and face. The stem has straight sides slightly contracting toward a rounded, convex base. The base also has been fractured, perhaps as a bottom effect from the same impact that sheared off the distal end. One shoulder is squared while the other is slightly barbed.

Specimen 2 (Fig. 26B) has one remaining long and straight blade edge; the other has been fractured off, as has the distal end, both fractures perhaps the results of manufacturing errors. The piece is thin in cross section and well flaked along its remaining edge. Flakes forming the stem are also well executed. Edges are sharp and unretouched. The existing shoulder is squared. The stem contracts to a rounded base.

Specimen 3 (Fig. 26C) is another apparent manufacturing failure. It has been fractured at its distal end, as well as along the base. Blade edges are convex and have been shaped by hard-hammer percussion. No soft-hammer flaking is present. Shoulders are ill formed; one is squared and one is rounded.

Specimen 4 (Fig. 26D) also appears to be an unfinished manufacturing failure. It has what remains of a triangular blade; the distal end has been fractured off, apparently from a manufacturing error. One shoulder is squared and one is slightly barbed. The stem contracts to a damaged base that is unfinished. Trimming flakes are present on both edges of one face.

Specimen 5 (Fig. 26E) is a proximal portion only. A small portion of one apparently squared shoulder is present; the other shoulder is missing. The stem is contracting to a rounded base. The stem shows no signs of final trimming. The specimen apparently broke during manufacture.

Straight-Stemmed(2 SPecimens, Fig. 26F,G)
Both of these specimens appear to be finished pieces that fractured after manufacturing. Both are missing their distal ends. Both are characterized by straight or nearly straight stems and slightly concave bases. Both have strong shoulders. Both are asymmetrical in plan view.

The first specimen (Fig. 26F) has convex blade edges and is a flat, thin, well-made tool. It resembles the Shumla type found frequently farther south and west of the Red Creek Site, except that it lacks the long sweeping barbs common to that type. One shoulder is barbed while the other is square. Measurements are: length, $5.5+\mathrm{cm}$; width, $4.5 \mathrm{~cm}$; thickness, $0.6 \mathrm{~cm}$; stem length, $1.6 \mathrm{~cm}$; stem width, $1.5 \mathrm{~cm}$. This specimen was recovered from Backhoe Trench 4, about $10 \mathrm{~cm}$ below the surface.

The second specimen (Fig. 26G) has straight blade edges and squared shoulders. Its stem is barely expanding and the base convex. Measurements are: length, $5.8+\mathrm{cm}$; width, $3.9 \mathrm{~cm}$; thickness, $0.6 \mathrm{~cm}$; length of stem, $1.4 \mathrm{~cm}$; width of stem, $1.7 \mathrm{~cm}$. Provenience is S9/E229, Level 2.

\section{Montell (1 Specimen, Fig. 26H)}

This specimen appears to be a M ontell failure. It has a roughed-out blade with a large insurmountable bulb located approximately in its center. One blade edge is concave, the other convex. The edges are only roughly formed by a series of irregular hard-hammer flakes. No further trimming or shaping has taken place on the edges. Shoulders with prominent barbs are present. One barb has been shaped through a series of pressure flakes; the other has not. The stem is expanding, with half of the outwardflaring base present; the other half has been fractured off, presumably during manufacture. Remnants of a basal notch are present. Measurements are: length, $7.1 \mathrm{~cm}$; width, $3.6 \mathrm{~cm}$; thickness, $1.2 \mathrm{~cm}$; length of stem, $1.5 \mathrm{~cm}$; width of stem, $1.1 \mathrm{tcm}$; depth of basal concavity, $0.5 \mathrm{~cm}$. The specimen was recovered from S2/E218, Level 1.

\section{Marcos (1 SPEcimen, Fig. 26I)}

This specimen is characterized by a broad, slightly convex, corner-notched base. The corner notching has created a prominent, well-pronounced barb on one shoulder; the other shoulder has been broken away. The distal end has been fractured off as well. The piece is well made, broad and flat, with fine bifacial retouch along the blade edges and basal edge. The stem has been thinned from the base through a series of fine, small pressure flakes. Measurements are: length, $4.8+\mathrm{cm}$; width, 3.6+ $\mathrm{cm}$; thickness, $0.7 \mathrm{~cm}$; length of stem/depth of comer notch, $1.1 \mathrm{~cm}$; width of stem, $2.6 \mathrm{~cm}$. This specimen was found on the surface. 


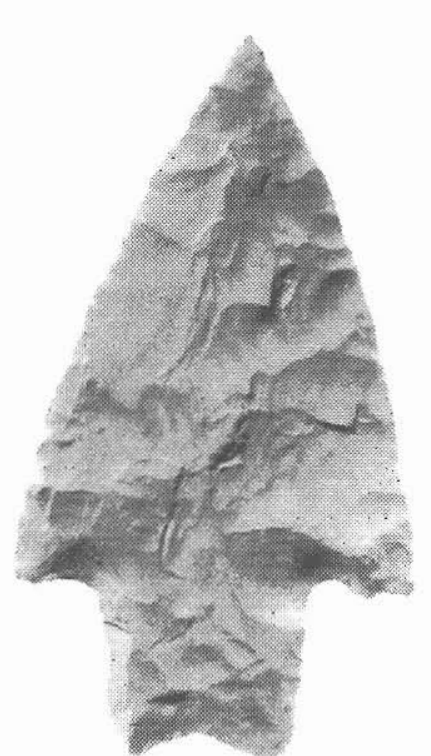

A

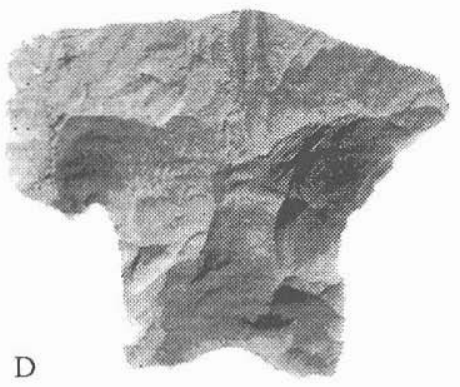

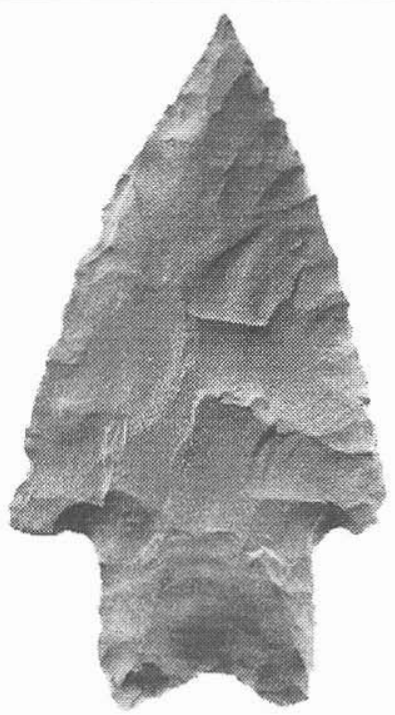

B

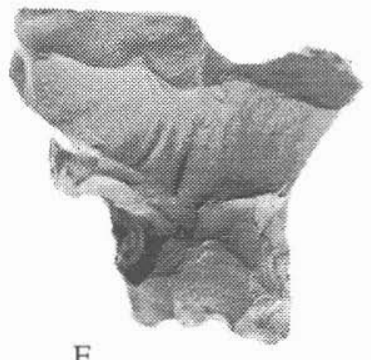

E

$$
\text { F }
$$
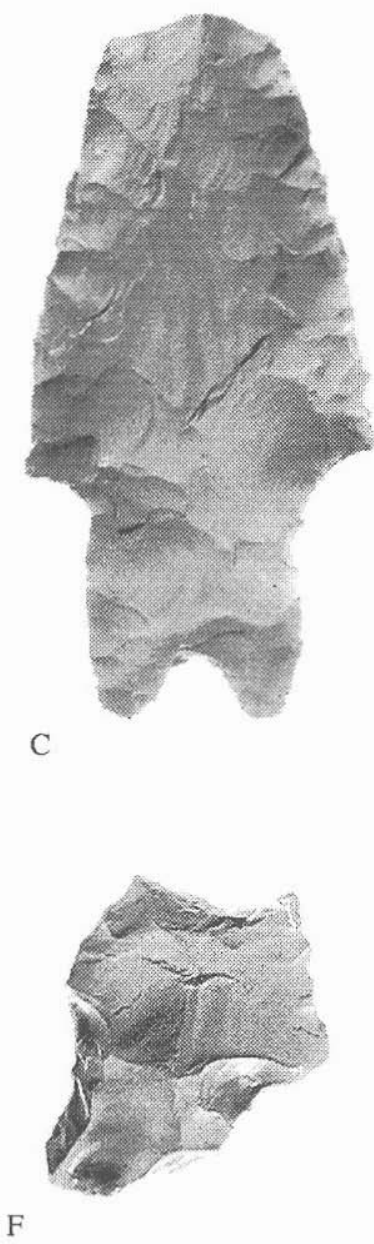

C

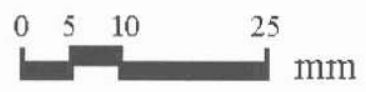

FIGURE 25. Pedernales projectile points

\section{Miscellaneous Dart-Point Fragments (41 SPECIMENS)}

Miscellaneous dart-point fragments include 8 distal ends, 9 medial sections, 22 barbs or shoulder fragments, and 2 basal fragments. None of the fragments can be placed into a recognized type. Provenience of these specimens is given in Table 7. As can be seen, dart-point fragments were fairly evenly dispersed throughout the site The same unit that contained high densities of other artifact types (S2/E218) also contained a fair amount of dart-point fragments.

\section{Miscellaneous Artifacts}

\section{Drills (2 SPecimens, Fig. 27A,B)}

Two drill fragments were recovered from the site. One specimen (Fig. 27A) is a bit end, $2.7 \mathrm{~cm}$ in length, broken off a larger tool. The tip is pointed and sharp, indicating little use prior to breakage. This tool was recovered from S2/E218, Level 3.

The other drill fragment (Fig. 27B) is a bifaced proximal portion, missing the bit. The artifact is $6 \mathrm{~cm}$ in length, with what remains of the drill bit measuring $1.3 \mathrm{~cm}$ 


\begin{tabular}{|l|c|c|c|c|c|c|l|}
\hline Specimen & $\begin{array}{c}\text { Length } \\
(\mathrm{cm})\end{array}$ & $\begin{array}{c}\text { Width } \\
(\mathrm{cm})\end{array}$ & $\begin{array}{c}\text { Thickness } \\
(\mathrm{cm})\end{array}$ & $\begin{array}{c}\text { Stem } \\
\text { Length } \\
(\mathrm{cm})\end{array}$ & $\begin{array}{c}\text { Stem } \\
\text { Width } \\
(\mathrm{cm})\end{array}$ & $\begin{array}{c}\text { Depth of Basal } \\
\text { Concavity } \\
(\mathrm{cm})\end{array}$ & \multicolumn{1}{|c|}{ Provenience } \\
\hline 1 (Fig. 25 A) & 7.3 & 4.0 & 0.7 & 1.9 & 2.1 & 0.3 & Surface of Feature 3 \\
\hline 2 (Fig. 25 B) & 7.1 & 3.9 & 0.7 & 2.2 & 2.3 & 0.4 & S1/E243, Level 1 \\
\hline 3 (Fig. 25 C) & $7.2+$ & 3.7 & 0.7 & 2.1 & 2.2 & 0.6 & S1/E221, Level 1 \\
\hline 4 (Fig. 25 D) & - & $4.5+$ & 0.7 & 1.8 & 2.3 & 0.4 & Backhoe Trench 4, 15 cm below surface \\
\hline 5 (Fig. 25 E) & - & - & 0.7 & 1.6 & 1.8 & 0.2 & Backhoe Trench 3, Surface \\
\hline 6 (Fig. 25 F) & - & - & 0.6 & - & 2.1 & - & S2/E223, Level 2 \\
\hline
\end{tabular}

\begin{tabular}{|l|c|c|c|c|c|l|}
\hline Specimen & $\begin{array}{c}\text { Length } \\
\text { (cm) }\end{array}$ & $\begin{array}{c}\text { Width } \\
\text { (cm) }\end{array}$ & $\begin{array}{c}\text { Thickness } \\
\text { (cm) }\end{array}$ & $\begin{array}{c}\text { Stem } \\
\text { Length } \\
\text { (cm) }\end{array}$ & $\begin{array}{c}\text { Stem } \\
\text { Width } \\
\text { (cm) }\end{array}$ & Provenience \\
\hline 1 (Fig. 26 A) & 4.8 & 3.2 & 0.6 & 1.5 & 1.4 & Backhoe Trench 4, 10 cm below surface \\
\hline 2 (Fig. 26 B) & $5.8+$ & $3.9+$ & 0.7 & 1.8 & 1.7 & S1/E243, Level 1 \\
\hline 3 (Fig. 26 C) & $5.8+$ & 3.8 & 1.1 & $1.7+$ & 2.6 & S4/E218, Level 1 \\
\hline 4 (Fig. 26 D) & $4.5+$ & 4.1 & 0.9 & 1.4 & 2.3 & S9/E229, Level 1 \\
\hline 5 (Fig. 26 E) & - & - & 0.6 & 1.9 & $1.8+$ & S4/E218, Level 2 \\
\hline
\end{tabular}


in length. This tool was recovered from S9/E229, Level 2.

These two drill fragments are not two broken pieces of a single tool; they are not of the same flint material.

\section{KNIFe (1 SPECIMEN, Fig. 27C)}

A single artifact was recovered that can be classified as a knife. It is a long, narrow blade, completely and expertly bifaced, and plano-convex in cross section. It measures $3.9 \mathrm{~cm}$ in length, $1.9 \mathrm{~cm}$ in width, and $0.5 \mathrm{~cm}$ in thickness. It is broken on both ends so that original length cannot be determined. Its width has also been decreased through use. Both edges exhibit extreme use wear. They have been dulled and blunted to the extent that an edge angle approaching $90^{\circ}$ is present. Apparently some resharpening has occurred, but this modification, too, has been blunted through use. The artifact was recovered from S2/E 223, Level 1.

\section{Pottery (1 specimen, Fig. 27D)}

A single, small, undecorated potsherd was recovered from the site. It measures $2 \mathrm{~cm}$ by $1.3 \mathrm{~cm}$ and is $0.6 \mathrm{~cm}$ thick. It appears to be bone-tempered. The sherd was recovered from S4/E 218. Level 1.

\section{CORES}

A total of 12 cores and core fragments were recovered from the site (Fig. 28), of which 10 have been reduced to small chunks with very little further potential. These "exhausted" core fragments average $4 \mathrm{~cm}$ in thickness and have had flakes remdved from all directions. Flake scars cover almost all the surfaces of all these specimens, although some cortex is present in every case.

Of the remaining cores, one (Fig. 28B) has been bifaced effectively on opposing sides to create a sharp, sinuous edge. Opposite this edge is a rounded section of cortex that fits snugly into the palm of the hand. This specimen resembles a crude hand axe or chopper, but the worked edge shows very little battering or wear.

The remaining specimen (Fig. 28C) has had a series of unidirectionalflakes removed from a prepared surface down one side of an otherwise unaltered core.

Provenience of cores is given in Table 8. Like the other tools, once again this artifact category was concentrated 2-3 $\mathrm{m}$ to the west and southwest of Feature 7. Again, this distribution should be viewed with caution. Theseareas of concentration are on a slope, downhill from the main body of the site, and may represent nothing more than the result of slopewash combined with displacement due to road-grading activities. 


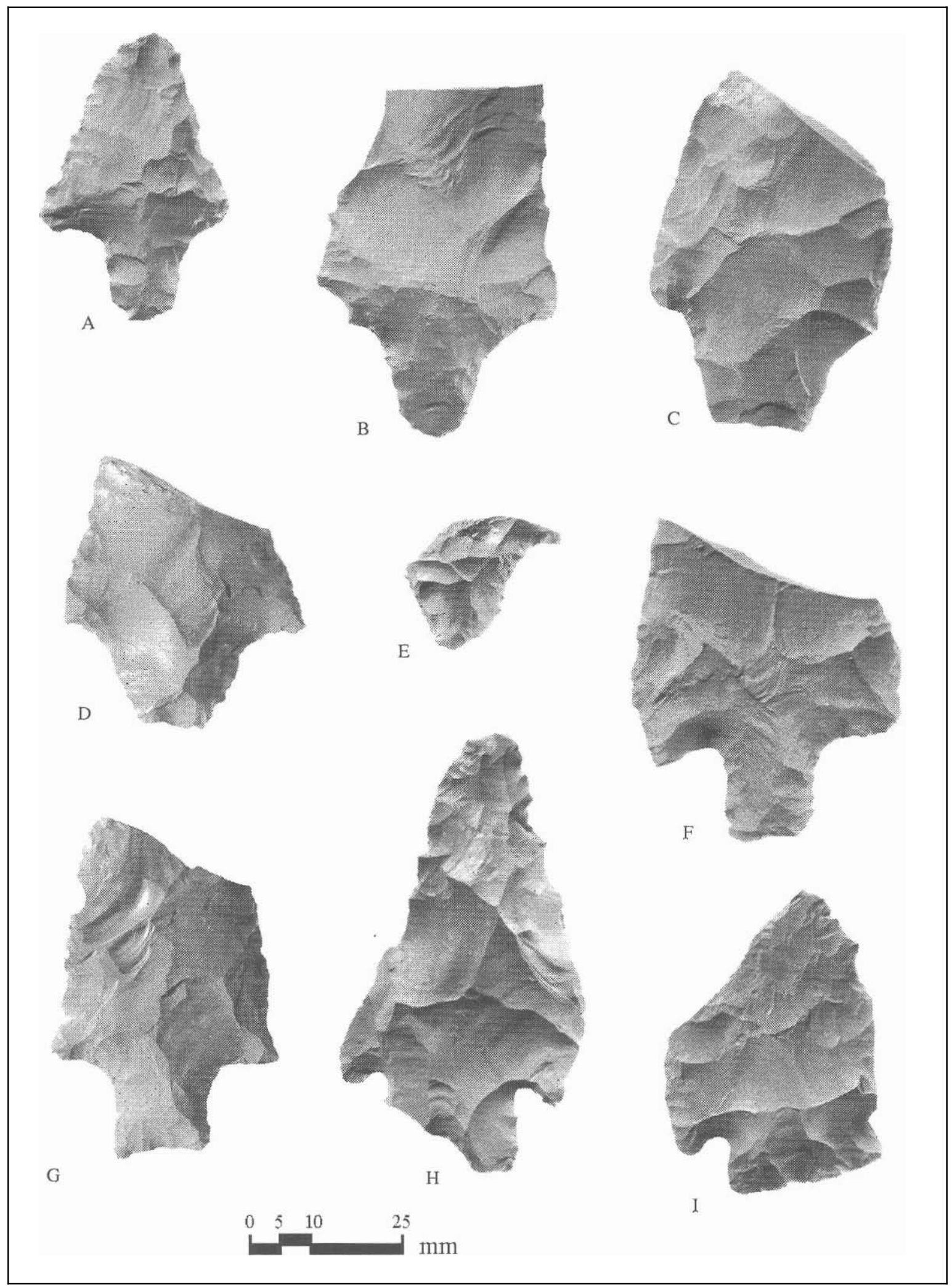

FIGURE 26. Projectile points. A-E, Contracting-Stemmed; F, G, Straight-Stemmed; H, Montell; I, Marcos 
TABLE 7. Provenience of miscellaneous dart-point fragments.

\begin{tabular}{|c|c|c|c|c|}
\hline 祐 & & 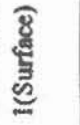 & & \\
\hline สิ & $\stackrel{\substack{n \\
\grave{3}}}{3}$ & & 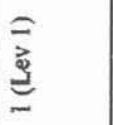 & \\
\hline$\frac{\sqrt{\pi}}{4}$ & & $\frac{a}{a}$ & 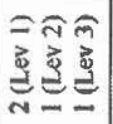 & $\stackrel{\substack{3 \\
3}}{3}$ \\
\hline 츌 & & $\frac{a}{3}$ & 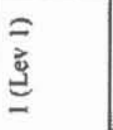 & \\
\hline 睎 & $\begin{array}{l}0 \\
\stackrel{a}{d} \\
\stackrel{a}{d}\end{array}$ & & & \\
\hline స్త్ & $\frac{a}{d}$ & $\underset{3}{3}$ & $\underset{\Xi}{\stackrel{0}{z}}$ & \\
\hline స్త్ & & $\begin{array}{l}\text { ส } \\
\stackrel{3}{d} \\
=\end{array}$ & 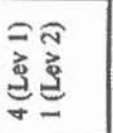 & \\
\hline สู & 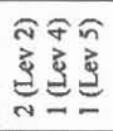 & & 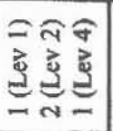 & $\begin{array}{l}a \\
3 \\
3 \\
=\end{array}$ \\
\hline क & & & ב- & \\
\hline 雬 & 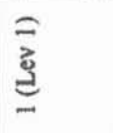 & & 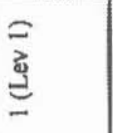 & \\
\hline జี్้జ & & & 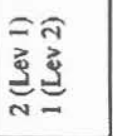 & \\
\hline ส্ & & 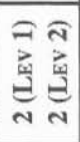 & 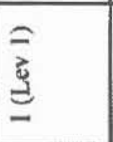 & \\
\hline 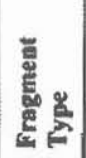 & 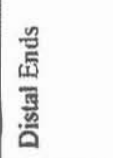 & 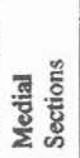 & 总总 & 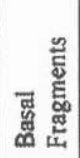 \\
\hline
\end{tabular}

TABLE 8. Provenience of cores.

\begin{tabular}{|c|c|}
\hline$\overbrace{0}^{\frac{\infty}{7}}$ & $\begin{array}{l}\widehat{\pi} \\
\vdots \\
\stackrel{J}{d} \\
-\end{array}$ \\
\hline 점 & 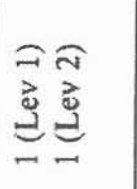 \\
\hline 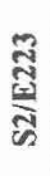 & 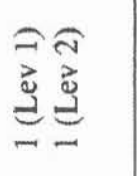 \\
\hline$\frac{\infty}{\sqrt{y}}$ & 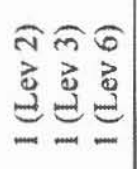 \\
\hline 莺 & $\begin{array}{l}\frac{a}{3} \\
\stackrel{0}{d} \\
=\end{array}$ \\
\hline 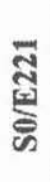 & $\begin{array}{l}a \\
\vec{a} \\
\stackrel{a}{a}\end{array}$ \\
\hline$\frac{\sum_{z}^{\infty}}{z}$ & 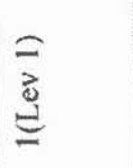 \\
\hline 芯 & - \\
\hline
\end{tabular}




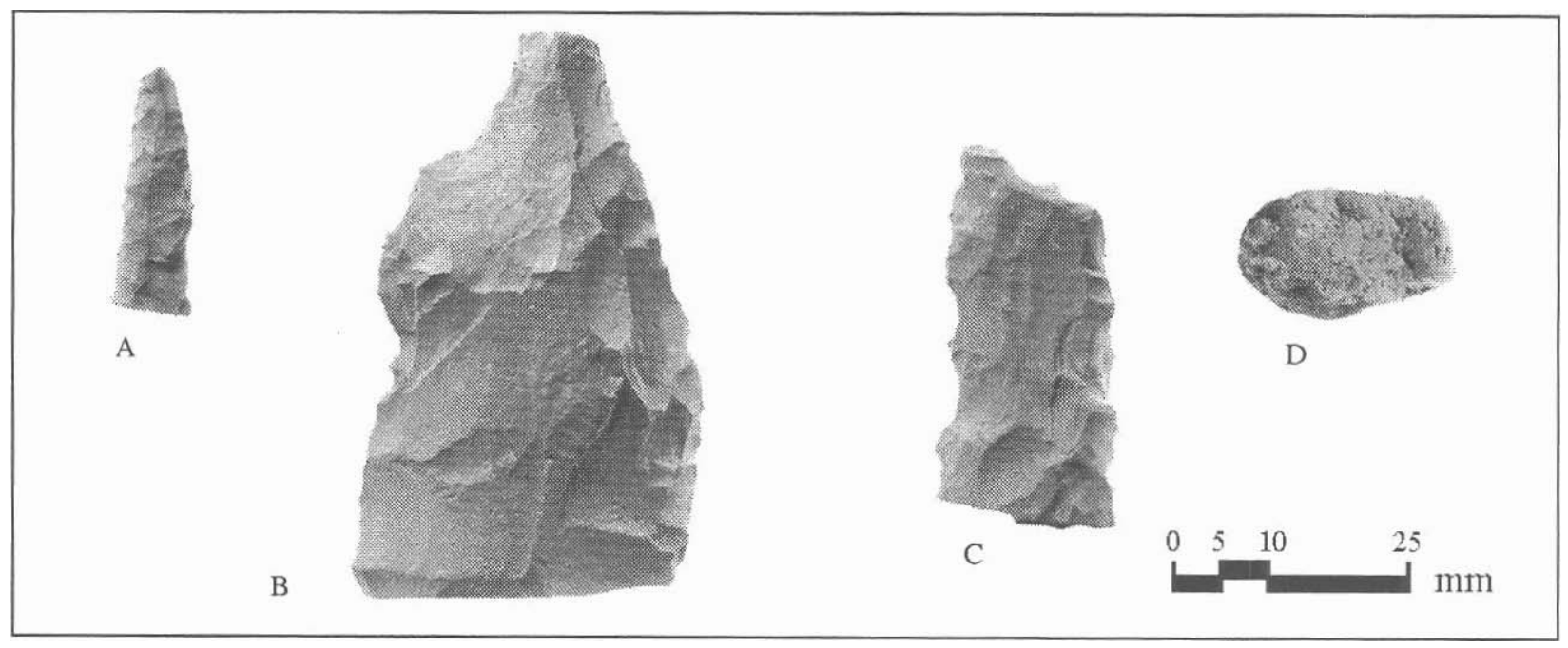

FIGURE 27. Miscellaneous artifacts. A, B, drill fragments; C, knife; D, potsherd.

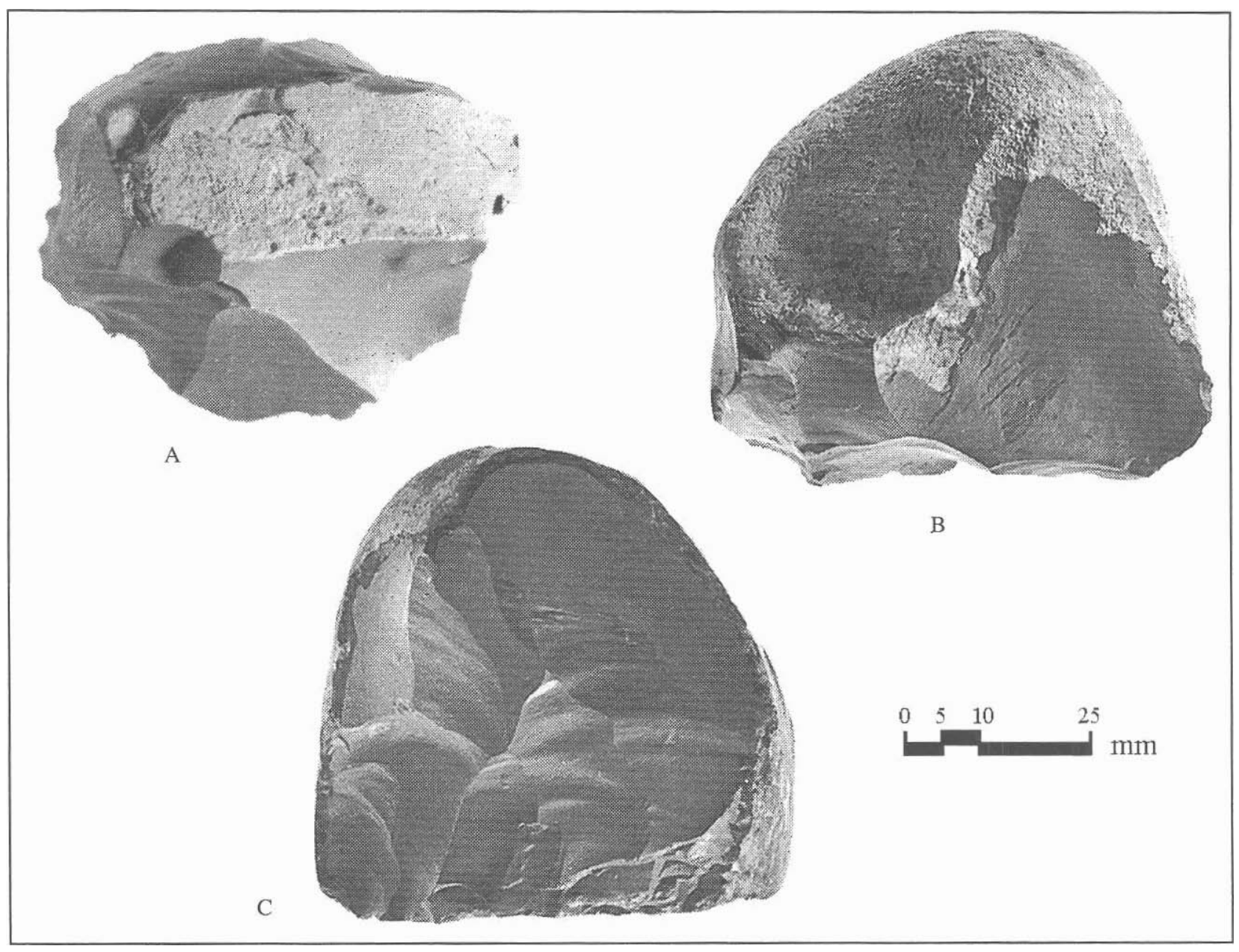

FIGURE 28. Cores. 


\section{INTERPRETATIONS AND CONCLUSIONS}

A synopsis of the diagnostic artifacts is presented in Table 9. As can be seen, at least one specimen representing nearly every cultural phase known to have occurred in Central Texas was recovered.

Notably absent were artifacts representing the Paleoindian Period. As has been said, intact Paleoindian sites are very rare. Most recovered Paleoindian artifacts are surface finds or the results of unique situations in which buried paleosols were fortuitously preserved, then fortuitously exposed, recognized, and investigated. No paleosols were present in the investigations at Red Creek. Centuries of denuding, deflation, and erosion at the site have obscured or removed any traces of ancient soils in the area studied.

A transitional Late Paleoindian/E arly Archaic projectile-point fragment, the Angostura-like base, was recovered. This specimen was recovered from Level 2 in Unit S2/E218, which indicates that the artifact was out of context. This type would be expected to have occurred much deeper in Unit S2/E 218, which contained cultural deposits to a depth of $60 \mathrm{~cm}$. Materials of a younger age were found at greater depths in this unit. Nonetheless, the recovery of this type indicates that cultural groups of the transitional period between Late Paleoindian and Early Archaic habituated the Red Creek area. Even if the specimen had been found and then recycled into the site by later Archaic peoples, its presence indicates that earlier groups had been in the vicinity of the site.

According to Weir's (1976) scheme, the Angostura point is representative of the terminal Paleoindian Period, around 8000 B.P. to 7000 B.P. Prewitt's (1981a) scheme places the type in the earliest Archaic sequence around 8500 B.P. to 7000 B.P. The time frame is the same; the nomenclature implies different subsistence strategies. Surely the change from Paleoindian to Archaic was a gradual one and the Angostura type probably reflects that gradual transition.

Other Early Archaic evidence at the Red Creek Site includes an Early-Stemmed specimen resembling the Gower/U valde type, a Bell barb, and a reworked Andice piece. These types represent the San Geronimo Phase (7000 B.P. to 5000 B.P.) as defined by Weir (1976). In Prewitt's (1981a) scheme, the Early-Stemmed specimen represents the San Geronimo Phase (7000 B.P. to 6000 B.P.) while the Bell and Andice specimens represent the slightly younger Jarrell Phase (6000 B.P. to 5000 B.P.). Since all three specimens were found on the surface, an Early Archaic association with the burned-rock features at the site could not be established.

Repeated early Middle Archaic occupations at the
Red Creek Site are represented by a number of different types, including a Nolan specimen, a Travis-like specimen, a specimen resembling the $\mathrm{N}$ olan/T ravis tradition, a Bulverde-like specimen, and two Side-Notched specimens in the tradition of La Jita. These types fall within Weir's (1976) and Prewitt's (1981a) Clear Fork Phase, except that Prewitt would place the Bulverde type within the succeeding Marshall Ford Phase (Prewitt 1981a).

All but two of these specimens were found on the surface, so associations with other artifacts or burned-rock features within the site could not be established. The Travis-like specimen was recovered from Level 4 of S2/ E218, a level that did not produce any other diagnostics or burned-rock features. One of the Side-Notched specimens was recovered from within a small midden (Feature 4), so that association of this type with a burned-rock midden is firmly established. However, the midden was small and not investigated further, so its functional relationship with the rest of the site is unknown. According to Weir (1976) and Prewitt (1981a), burned-rock middens, especially Weir's Type 1 midden (the typical oval mound), were established by Clear Fork times (5000 B.P. to 4000 B.P.). Since several middens were present at the Red Creek Site, one of which contained the Side-Notched specimen, it is probably accurate to assume that some of these early Middle Archaic dart points were associated with the midden occupations. However, since no single type was recovered in abundance in association with the middens, it cannot be said that any one early Middle Archaic group was directly responsible for the accretion of the middens.

Following the Clear Fork Phase, the Red Creek Site seems to have seen a more intensive occupation or occupations during the Middle Archaic Round Rock Phase (Weir 1976; Prewitt 1981a), around 4000 B.P. to 2500 B.P. Based on numbers or percentages of recovered specimens, the Round Rock Phase appears to have been the time when the site was most heavily utilized. Six Pedernales points and five Contracting-Stemmed points resembling the Langtry type were recovered. Of these, two Pedernales specimens were recovered from the surface, two Pedernales and four Contracting-Stemmed points were recovered from Level 1, and two Pedernales and one Contracting-Stemmed point were recovered from Level 2.

Although there was no direct association with the burned-rock middens on site, the abundance of these types and their proximity to the middens suggest very strongly that the middens were associated with the Middle Archaic groups who produced these projectile-point types. Prewitt (1981a) has suggested that the burned-rock midden 
phenomenon was at its peak during the Round Rock Phase, and the small but nonetheless corroborative evidence from the Red Creek Site seems to substantiate that claim.

Following the Middle Archaic, the Red Creek Site was occupied around 2500 B.P. to 1750 B.P. by Weir's (1976) Late Archaic San Marcos Phase or Prewitt's (1981a)Late Archaic Uvalde Phase peoples. The artifacts include a single Montell and a single Marcos specimen. Two Straight-Stemmed specimens (one reminiscent of Turner and Hester's [1985] Shurnla type) might be considered as part of the Late Archaic occupations at Red Creek because of their affinities with Late Archaic sites in southwest Texas. The Marcos point was found on the surface, the Montell and the Shumla-like StraightStemmed were recovered from Level 1, and the other Straight-Stemmed specimen was recovered from Level 2. Since these proveniences are the same that yielded other, earlier types, very little can be said about intrasite relationships involving these Late Archaic types. Although Weir (1976) has proposed an affiliation with three types of burned-rock middens for the Montell and Marcos types, such an affiliation was not demonstrated at Red Creek.

Evidence of later Archaic occupations such as Weir's (1976) and Prewitt's (1981a)Twin Sisters Phase or Prewitt's (1981a) Driftwood Phase was not recovered at Red Creek. Of course, this lack of evidence does not imply that later groups were not there; it simply indicates that the requisite diagnostic materials were not present in the units excavated. Perhaps if a larger area had been tested, especially to the north in the richer portions of the site, a completely different picture, both in numbers and types of artifacts recovered, would emerge.

One final occupation is hinted at in the collection, and that is the Late Prehistoric Toyah Phase, around 650 B.P. to 200 B.P., represented by a single undecorated potsherd. The sherd was recovered from Level 1. Nothing much can be said about this occupation, other than perhaps the statement that late in the prehistory of the site, a group of Toyah peoples made a brief visit to the site and left behind a piece of a broken vessel. There is no connection between the potsherd and the midden accretion at Red Creek.

Testing of the Red Creek Site has produced evidence of a long series of occupations at the site. Since the provenience of most of the diagnostic artifacts was suspected to be the result of secondary deposition, comparison with other sites was relied on heavily to establish a sequence at Red Creek. The sequence includes a possible first occupation during Late Paleoindian times, an Early Archaic occupation, a more intense Middle Archaic occupation, a waning Late Archaic use of the site, and a final Late Prehistoric visit. The burned-rock middens present at the site but unexplored during our testing, are assumed to have been the accumulated work of the early-Middle and Middle Archaic inhabitants.

The site locality is certainly ideal in terms of proximity to resources, and it no doubt served as home to many a wandering group for many centuries. The site, as it lies within the Texas Department of Transportation right-of-way, has been concealed and is now protected for future generations. 
TABLE 9. Synopsis of diagnostic artifacts.

\begin{tabular}{|l|c|c|}
\hline \multicolumn{1}{|c|}{ Type } & Number of Specimens & Vertical Provenience \\
\hline $\begin{array}{c}\text { Angostura-like } \\
\text { (G ower/UvaldeFamily) }\end{array}$ & 1 & Level 2 \\
\hline $\begin{array}{l}\text { Early-Stemmed } \\
\text { Andice }\end{array}$ & 1 & Surface \\
\hline Bell & 1 & Surface \\
\hline $\begin{array}{l}\text { Side-Notched } \\
\text { (La) ita Family) }\end{array}$ & 1 & Surface \\
\hline Bulverde-like & 1 & Surface \\
\hline Nolan & 1 & Feature 4 \\
\hline Travis-like & 1 & Surface \\
\hline Nolan/TravisFamily & 1 & Surface \\
\hline $\begin{array}{l}\text { Pedernales } \\
\text { (Langtry Family) }\end{array}$ & 1 & Level 4 \\
\hline Contracting-Stemmed & Surface. \\
\hline Straight-Stemmed \\
(1 Shumla Family)
\end{tabular}




\section{References Cited}

Alexander, Herbert L., Jr.

1963 The Levi Site: A Paleoindian Campsite in Central Texas. American Antiquity 28:510-528.

Blair, W. Frank

1950 The Biotic Provinces of Texas. The Texas Journal of Science 2(1):93-117.

Brown, T.M., Kay L. Killen, Helen Simons, and Virginia Wulfkuhle

1982 Resource Protection Planning Process for Texas. Texas Historic Commission. Austin.

Carr, John T.

1967 The Climate and Physiography of Texas. Texas Water Development Board Report 53. Austin.

Creel, Darrell Glenn

1986 A Study of Prehistoric Burned Rock Middens in West Central Texas. Ph.D. dissertation, Department of Anthropology, The University of Arizona.

Fenneman, Nevin M.

1938 Physiography of the Eastern United States. McGraw-Hill Book Company, Inc. New York.

Goode, Glenn T.

1988 Results of Testing and Research Design for Mitigation of Site 41MS32, A Burned Rock Midden Site in Mason County, Texas. Report on file at the Texas Department of Transportation, Environmental Affairs Division. Austin.

1992 Personal Communication. Conversation with the author in the offices of the Texas Department of Transportation, Environmental Affairs Division. Austin.

m.s . The Schoolhouse Site, 41 UV86. Manuscript on file at the Texas Department of Transportation, Environmental Affairs Division. Austin.

Gould, F.W.

1969 Texas Plants - A Checklist and Ecological Summary. Texas A\&M University. College Station.
Gunn, Joel, and Royce Mahula

1977 Hop Hill: Culture and Climatic Change in Central Texas. Special Report 5. Center for Archaeological Research, The University of Texas at San Antonio.

Henderson, Jerry

1983 The Pavo Real Site Paleoindian Component. Article on file at the Texas Department of Transportation, Environmental Affairs Division. Austin.

n.d. The Heard Site, 41UV88, An Archaic Burned Rock Midden Site in Uvalde County, Texas. Report on file at the Texas Department of Transportation, Environmental Affairs Division. Austin.

m.s. Excavations at the Rainey Site, a Lute Prehistoric Sinkhole Site in Bandera County, Texas. Manuscript on file at the offices of the Texas Department of Transportation, Environmental Affairs Division. Austin.

Jelks, Edward B.

1962 The Kyle Site: A Stratified Central Texas Aspect Site in Hill County, Texas. Department of Anthropology Archaeology Series 5. The University of Texas at Austin.

Johnson, LeRoy, Jr.

1994 The Life and Times of Toyah-Culture Folk: The Buckhollow Encampment, Site 41KM16, Kimble County, Texas. O ffice of the State Archaeologist Report 38. Texas Department of Transportation and Texas Historical Commission. Austin.

Luke, Clive J.

1980 Continuing Archaeology on State Highway 16: The Shep Site (41KR109) and The Wounded Eye Site (41KR107). Publications in Archaeology 16. State Department of Highways and Public Transportation, Highway Design Division. Austin. 
Patterson, Patience Elizabeth

1987 Archaeological Excavations at 41LL78, The Slab Site, Llano County, Texas. Publications in Archaeology 34. State Department of Highways and Public Transportation, Highway Design Division. Austin.

Prewitt, Elton R.

1981 aCultural Chronology in Central Texas. Bulletin of the Texas Archaeological Society 52:65-90.

1981b Archeological Investigations at Loeve-Fox, Loeve, and Tombstone Bluff Sites in the Granger Luke District of Central Texas. M.S. submitted to the Institute of Applied Sciences, North Texas State University. Denton.

Shafer, Harry J.

1971 Late Prehistory of Central Texas, 500 B.C.1700 A.D. Paper presented at the 74th Annual Meeting of the Texas Academy of Science. Nacogdoches, Texas.

Soil Conservation Service

1982 Soil Survey of Kimble County, Texas. U.S. Department of Agriculture in cooperation with the Texas Agricultural Experiment Station.

State Department of Highways and Public Transportation 1988 Archaeological Site 41KM3 in Kimble County, FM 3480: From U.S. 377,6.5 Miles South of London, to FM 385 at Yates Crossing. Interoffice memorandum from Frank D. Holzmann to Raymond E. Stotzer dated July 13, 1988. Copy on file at the Texas Department of Transportation, Environmental Affairs Division. Austin.

Suhm, Dee Ann

1957 Excavations at the Smith Rockshelter,Travis County, Texas. Texas Journal of Science 9(1):26-58.
Turner, Ellen Sue, and Thomas R. Hester

1985 A Field Guide to Stone Artifacts of Texas Indians. Texas Monthly Field Guide Series. Texas Monthly Press. Austin.

Young, Wayne C.

1985a A Preliminary Report on the Wilson-Leonard Site, 41 WM235, A Major Paleoindian and Early Archaic Site in Central Texas. M.S. on file in the offices of the Texas Department of Transportation,Environmental Affairs Division. Austin.

1985b Archaeological Excavations at Site 41BT6: Burnet County, Texas. Publications in Archaeology 28. State Department of Highways and Public Transportation, Highway Design Division. Austin.

1986 Archaeological Investigations in Eastern Kimble County, Texas. Publications in Archaeology 30. State Department of Highways and Public Transportation, Highway Design Division. Austin.

1987 Archaeological Investigations at The Ammons Crossing Site, 41KE93, Kendall County, Texas. Publications in Archaeology 36. State Department of Highways and Public Transportation, Highway Design Division. Austin.

Weir, Frank A.

1976 The Central Texas Archaic. Ph.D. dissertation, Department of Anthropology, Washington State University. Pullman. 